

\section{Editorial Board}

\section{Editor in Chief}

Mark Zilberman, MSc, Shiny World Corporation, Toronto, Canada

\section{Scientific Editorial Board}

Viktor Andrushhenko, PhD, Professor, Academician of the Academy of Pedagogical Sciences of Ukraine, President of the Association of Rectors of pedagogical universities in Europe

John Hodge, MSc, retired, USA

Petr Makuhin, PhD, Associate Professor, Philosophy and Social Communications faculty of Omsk State Technical University, Russia

Miroslav Pardy, PhD, Associate Professor, Department of Physical Electronics, Masaryk University, Brno, Czech Republic

Lyudmila Pet'ko, Executive Editor, PhD, Associate Professor, National Pedagogical Dragomanov University, Kiev, Ukraine

\section{Intellectua|Archive, Volume 7, Number 6}

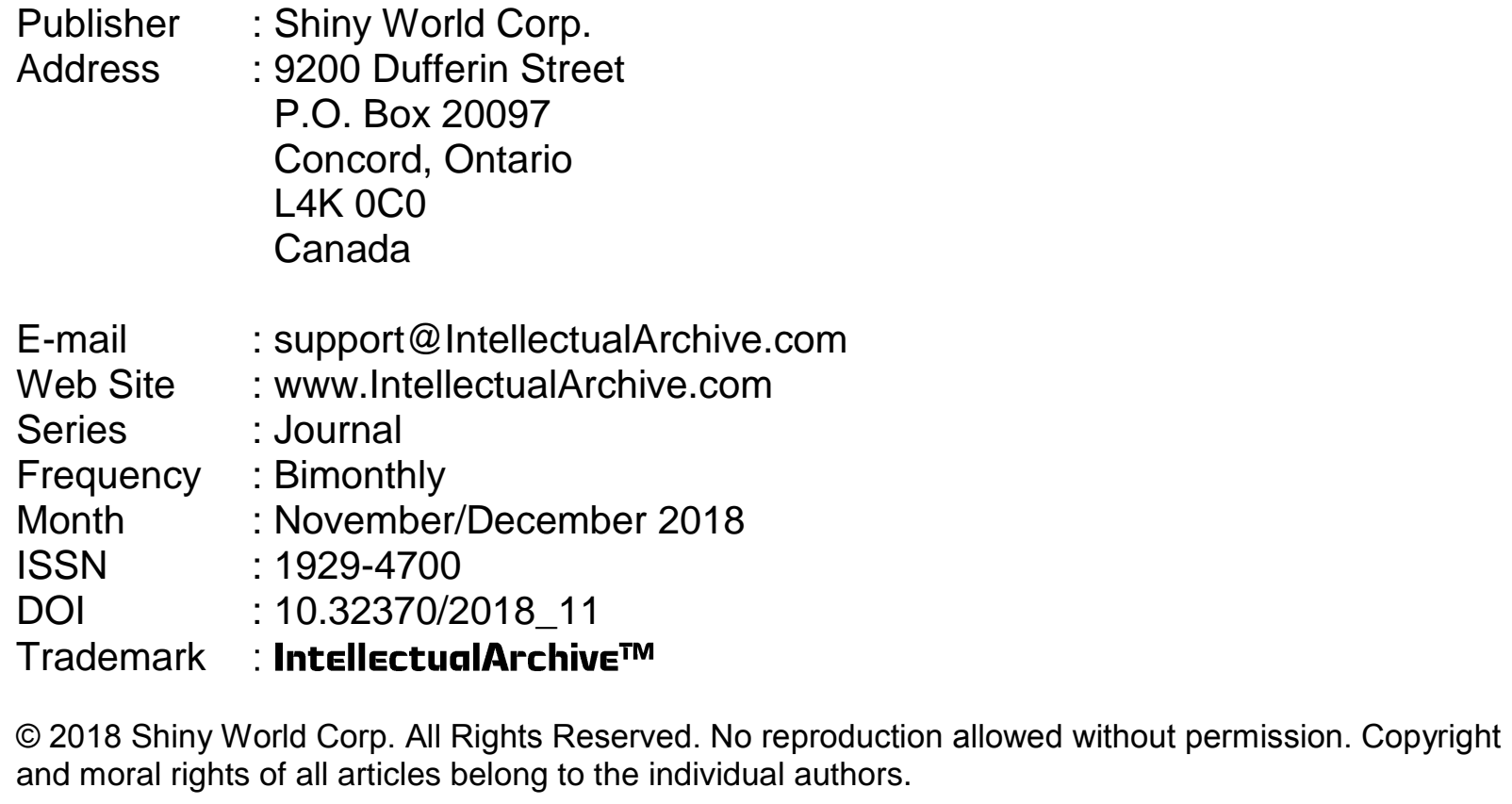

(C) 2018 Shiny World Corp. All Rights Reserved. No reproduction allowed without permission. Copyright and moral rights of all articles belong to the individual authors. 


\section{Intellectual Archive}

Volume 7

M. Pardy

A. Bolonkin

Number 6

November/December 2018

\section{Table of Contents}

\section{Physics}

Quantum theory of the dispersion of the laser light

Technology

Low Inductive and Resistance Energy Capacitor

History

Umar Lawal Aliyu

Location of Industry

\section{Computer science}

Umar Lawal Aliyu Computer Crime

\section{Mathematics}
R. Mustafaev,
E. Klyueva,
G. Boytsun

N. Shandra

S. Abdurakhmanov

H. Safayev

V. Pilipenko

V. Stepanov

R. Bobovsky

O. Komarovska, Xia Gaoyang

Qiao Zhi
The Cook-Levine Hypothesis. Equality of Classes, $\mathrm{P}=\mathrm{PN}$ (Easily Solvable

Problems Are Easily Checked)

\section{Education}

Specific Features of Professionally Oriented Written Communication in English of IT Specialists

Ways of Improvement of Pedagogical Skill of Commanders

The Issue of Civic Education of A Person in the Pedagogical Heritage of Olexander Stronin

Determination of Theoretical and Methodological Principles of Teaching Multimedia Arrangement of Future Music Teachers in the Process of Professional Training .....

To Solve the Problem of Improving Level of Developing a Pedagogical Consciousness in a Future Math Teacher

Polyartistic Potential of Music Theory Subjects in Training Music Teachers

82

Ethno-Artistic Competence of Student Youth: Diagnostic Procedure 


\section{Table of Contents (continued)}

\section{Social Work}

N. Chernukha, M. VasylievaKhalatnykova, The Technology for Forming Professional Reflection in Future Social Work Educators in a Higher Educational Institution

L. Tokaruk

Toronto, November/December 2018 


\title{
Quantum theory of the dispersion of the laser light
}

\author{
Miroslav Pardy \\ Department of Physical Electronics \\ Faculty of Science, Masaryk University \\ Kotlářská 2, 61137 Brno, Czech Republic \\ e-mail:pamir@physics.muni.cz
}

November 21, 2018

\begin{abstract}
We derive the index of refraction of light from quantum theory of atoms and from the Dirac equation with the plane wave. The result is the integral a part of the mainstream of the quantum optics. The article involves also discussion on the possibility to create the electron-positron pairs during the Čerenkov process with the adequate intex of refraction.
\end{abstract}

\section{Introduction}

The refractive index of materials varies with the frequency of light. This is called dispersion and causes prisms and rainbows to divide white light into its constituent spectral colors. This effect was described by Jan Marcus Marci (1668) and Newton (1686) in the old age of optics.

The contemporary explanation of this effect is as follows. An electromagnetic wave phase velocity is slowed in a medium because the electric field creates a disturbance in the charges of each atom (primarily the electrons). As the electromagnetic fields oscillate in the wave, the charges in the material will be oscillating at the same frequency.

The charges thus radiate their own electromagnetic wave at the same frequency, but usually with a phase delay, as the charges may move out of phase with the force driving them. The light wave traveling in the medium is the macroscopic superposition of the original wave plus the waves radiated by all the moving charges. This wave is typically a wave with the same frequency but shorter wavelength than the original, leading to a slowing of the wave phase velocity. Most of the radiation from oscillating material charges will modify the incoming wave, changing its velocity. 


\section{The quantum theory dispersion}

We suppose that electrons in atoms are in the same quantum state. The perturbation method is adequate for the application in a medium because the interaction energy of atoms with the external field is very small in comparison with the energy of electrons in atoms.

The impinging wave of electromagnetic field is of the form $E=E_{0} \cos (\omega t-2 \pi x / \lambda)$. With regard to the fact that $\lambda \sim 10^{-5} \mathrm{~cm}$ and atom is of the size $a \sim 10^{-8} \mathrm{~cm}$, the quantity $x / \lambda$ can be neglected in the electromagnetic wave and we write

$$
E=E_{0} \cos (\omega t-2 \pi x / \lambda) \rightarrow E=E_{0} \cos (\omega t)
$$

So, the quantum theory of dispersion can be derived in the framework of the nonrelativistic Schrödinger equation (Sokolov et al., 1962) for an electron moving in dielectric medium and in the field with the periodic force

$$
F_{x}=-e E_{0} \cos \omega t, \quad F_{y}=F_{z}=0 .
$$

Then, the corresponding potential energy is

$$
V^{\prime}=e x E_{0} \cos \omega t
$$

and this potential energy is the perturbation energy in the Schrödinger equation

$$
\left(i \hbar \frac{\partial}{\partial t}-H_{0}-V^{\prime}\right) \psi_{k}(t)=0
$$

where for $V^{\prime}=0$ it is $\psi_{k}(t) \rightarrow \psi_{k}^{0}(t)$ and

$$
\psi_{k}^{0}(t)=\psi_{k}^{0} e^{-\frac{i}{\hbar} E_{k} t}=\psi_{k}^{0} e^{-i \omega_{k} t},
$$

where $\psi_{k}^{0}$ is the solution of the Schrödinger equation without perturbation, or,

$$
\left(i \hbar \frac{\partial}{\partial t}-H_{0}\right) \psi_{k}^{0}(t)=0
$$

We are looking for the solution of the Schrödinger equation involving the perturbation potential in the form

$$
\psi_{k}(t)=\psi_{k}^{0}(t)+\psi_{k}^{1}(t)
$$

where $\psi_{k}^{1}(t)$, is the perturbation wave function correction to the non-perturbation wave function.

After insertion of formula (7) to eq. (4), we get

$$
\left(i \hbar \frac{\partial}{\partial t}-H_{0}\right) \psi_{k}^{1}(t)=\frac{1}{2} e x E_{0} \psi_{k}^{0}\left(e^{-i t\left(\omega_{k}-\omega\right)}+e^{-i t\left(\omega_{k}+\omega\right)}\right) .
$$

Let us look for the solution of eq. (8) in the form: 


$$
\psi_{k}^{1}(t)=u e^{-i t\left(\omega_{k}-\omega\right)}+v e^{-i t\left(\omega_{k}+\omega\right)} .
$$

After insertion of (9) into (8), we get two equations for $u$ and $v$ :

$$
\begin{aligned}
\left(\hbar\left(\omega_{k}-\omega\right)-H_{0}\right) u & =\frac{1}{2} e x E_{0} \psi_{k}^{0}, \\
\left(\hbar\left(\omega_{k}+\omega\right)-H_{0}\right) v & =\frac{1}{2} e x E_{0} \psi_{k}^{0} .
\end{aligned}
$$

Then, using the formal expansion

$$
u=\sum_{k^{\prime \prime}} C_{k^{\prime \prime}} \psi_{k^{\prime \prime}}^{0}
$$

we get from eq.

$$
\left(E_{k^{\prime \prime}}-H_{0}\right) \psi_{k^{\prime \prime}}^{0}=0
$$

the following equation

$$
\hbar \sum_{k^{\prime \prime}} C_{k^{\prime \prime}}\left(\omega_{k k^{\prime \prime}}-\omega\right) \psi_{k^{\prime \prime}}^{0}=\frac{e x E_{0}}{2} \psi_{k}^{0}
$$

with

$$
\omega_{k k^{\prime \prime}}=\frac{E_{k}-E_{k^{\prime \prime}}}{\hbar}
$$

Using the orthogonal relation

$$
\int \psi_{k^{\prime}}^{0 *} \psi_{k^{\prime \prime}}^{0} d^{3} x=\delta_{k^{\prime} k^{\prime \prime}}
$$

we get the following relation for $C_{k}$ and $u$ as follows:

$$
\begin{gathered}
C_{k}=-\frac{e E_{0}}{2 \hbar} \cdot \frac{x_{k^{\prime} k}}{\omega_{k^{\prime} k}+\omega}, \\
u=\sum_{k^{\prime}}\left(-\frac{e E_{0}}{2 \hbar}\right) \cdot \frac{x_{k^{\prime} k}}{\omega_{k^{\prime} k}+\omega} \psi_{k^{\prime}}^{0}
\end{gathered}
$$

and $v=u(-\omega)$, or

$$
v=\sum_{k^{\prime}}\left(-\frac{e E_{0}}{2 \hbar}\right) \cdot \frac{x_{k^{\prime} k}}{\omega_{k^{\prime} k}-\omega} \psi_{k^{\prime}}^{0}
$$

and

$$
x_{k^{\prime} k}=\int \psi_{k^{\prime}}^{0 *} x \psi_{k}^{0} d^{3} x .
$$

The general wave function can be obtained from eqs. (7), (9), (18) and (19) in the form: 


$$
\begin{gathered}
\psi_{k}(t)=e^{-i \omega_{k} t} \times \\
\left\{\psi_{k}^{0}-\frac{e E_{0}}{\hbar} \sum_{k^{\prime}} \frac{x_{k^{\prime} k}}{\omega_{k^{\prime} k}^{2}-\omega^{2}} \psi_{k^{\prime}}^{0}\left[\omega_{k^{\prime} k} \cos \omega t-i \omega \sin \omega t\right]\right\} .
\end{gathered}
$$

The classical polarization of a medium is given by the well known formula

$$
P=N p=-N e x,
$$

where $\mathrm{N}$ is the number of atom in the unite volume of dielectric medium. So we are able to define the quantum analogue form of the polarization as it follows:

$$
P=N \bar{p}=-N e \int \psi_{k}^{*}(t) x \psi_{k}(t) d^{3} x,
$$

or, with

$$
\int \psi_{k}^{0 *} x \psi_{k}^{0} d^{3} x=0
$$

we have

$$
P=\sum_{k^{\prime}}\left(2 \frac{N e^{2} E_{0}}{\hbar}\right) \cdot \frac{\omega_{k^{\prime} k}\left|x_{k^{\prime} k}\right|^{2}}{\omega_{k^{\prime} k}^{2}-\omega^{2}} \cos \omega t .
$$

Using the classical formula for polarization $P$,

$$
\mathbf{P}=\frac{n^{2}-1}{4 \pi} \mathbf{E},
$$

we get for the quantum model of polarization

$$
\frac{n^{2}-1}{4 \pi}=\sum_{k^{\prime}}\left(2 \frac{N e^{2}}{\hbar}\right) \cdot \frac{\omega_{k^{\prime} k}\left|x_{k^{\prime} k}\right|^{2}}{\omega_{k^{\prime} k}^{2}-\omega^{2}} .
$$

Using the definition of the coefficients $f_{k^{\prime} k}$ by relation

$$
f_{k^{\prime} k}=\frac{2 m}{\hbar} \omega_{k^{\prime} k}\left|x_{k^{\prime} k}\right|^{2},
$$

we get the modified equation (27) as follows:

$$
\frac{n^{2}-1}{4 \pi}=\frac{N e^{2}}{m} \sum_{k^{\prime}} \frac{f_{k^{\prime} k}}{\omega_{k^{\prime} k}^{2}-\omega^{2}} .
$$

The last formula should be compared with the classical one:

$$
\frac{n^{2}-1}{4 \pi}=\frac{e^{2}}{m} \sum_{k} \frac{N_{k}}{\omega_{k}^{2}-\omega^{2}},
$$

where $N_{k}$ is number of electrons moving with frequency $\omega_{k}$ in the unit volume.

Let us renark that the oscillator coeficients $f_{k^{\prime} k}$ in eq. (29) can have also the negative values. It leads to the special behaviour of the dispersion. Namely, dispersion is negative. The negative dispersion was discovered by Ladenburg $(1921 ; 1930)$. 


\section{Volkov solution of the Dirac equation}

We follow the method of derivation and metric convention of (Berestetsky et al., 1989):

$$
(\gamma(p-e A)-m) \psi=0
$$

where

$$
A^{\mu}=A^{\mu}(\varphi) ; \quad \varphi=k x=\omega t-\mathbf{k x}
$$

We suppose that the four-potential satisfies the Lorentz gauge condition

$$
\partial_{\mu} A^{\mu}=k_{\mu}\left(A^{\mu}\right)^{\prime}=\left(k_{\mu} A^{\mu}\right)^{\prime}=0,
$$

where the prime denotes derivative with regard to $\varphi$. From the last equation follows

$$
k A=\text { const }=0,
$$

because we can put the constant to zero. The tensor of electromagnetic field is

$$
F_{\mu \nu}=k_{\mu} A_{\nu}^{\prime}-k_{\nu} A_{\mu}^{\prime} .
$$

Instead of the linear Dirac equation (31), we consider the quadratic equation, which we get by multiplication of the linear equation by operator $(\gamma(p-e A)+m)$ (Berestetzkii et al., 1989). We get:

$$
\left[(p-e A)^{2}-m^{2}-\frac{i}{2} e F_{\mu \nu} \sigma^{\mu \nu}\right] \psi=0 .
$$

Using $\partial_{\mu}\left(A^{\mu} \psi\right)=A^{\mu} \partial_{\mu} \psi$, which follows from eq. (34), and $\partial_{\mu} \partial^{\mu}=\partial^{2}=-p^{2}$, with $p_{\mu}=i\left(\partial / \partial x^{\mu}\right)=i \partial_{\mu}$, we get the quadratic Dirac equation for the four potential of the plane wave:

$$
\left[-\partial^{2}-2 i e(A \partial)+e^{2} A^{2}-m^{2}-i e(\gamma k)\left(\gamma A^{\prime}\right)\right] \psi=0 .
$$

We are looking for the solution of the last equation in the form:

$$
\psi=e^{-i p x} F(\varphi) .
$$

After insertion of eq. (33) into eq. (32), we get with $\left(k^{2}=0\right)$

$$
\partial^{\mu} F=k^{\mu} F^{\prime}, \quad \partial_{\mu} \partial^{\mu} F=k^{2} F^{\prime \prime}=0,
$$

the following equation for $F(\varphi)$

$$
2 i(k p) F^{\prime}+\left[-2 e(p A)+e^{2} A^{2}-i e(\gamma k)\left(\gamma A^{\prime}\right)\right] F=0 .
$$

The integral of the last equation is of the form (Berestetzkii et al., 1989): 


$$
F=\exp \left\{-i \int_{0}^{k x}\left[\frac{e(p A)}{(k p)}-\frac{e^{2}}{2(k p)} A^{2}\right] d \varphi+\frac{e(\gamma k)(\gamma A)}{2(k p)}\right\} \frac{u}{\sqrt{2 p_{0}}},
$$

where $u / \sqrt{2 p_{0}}$ is the arbitrary constant bispinor.

$\mathrm{Al}$ powers of $(\gamma k)(\gamma A)$ above the first are equal to zero, since

$$
\begin{gathered}
(\gamma k)(\gamma A)(\gamma k)(\gamma A)= \\
-(\gamma k)(\gamma k)(\gamma A)(\gamma A)+2(k A)(\gamma k)(\gamma A)=-k^{2} A^{2}=0 .
\end{gathered}
$$

where we have used eq. (4) and relation $k^{2}=0$. Then we can write:

$$
\exp \left\{e \frac{(\gamma k)(\gamma A)}{2(k p)}\right\}=1+\frac{e(\gamma k)(\gamma A)}{2(k p)} .
$$

So, the solution is of the form:

$$
\psi_{p}=R \frac{u}{\sqrt{2 p_{0}}} e^{i S}=\left[1+\frac{e}{2 k p}(\gamma k)(\gamma A)\right] \frac{u}{\sqrt{2 p_{0}}} e^{i S},
$$

where $u$ is an electron bispinor of the corresponding Dirac equation

$$
(\gamma p-m) u=0
$$

and we shall take it to be normalized by condition $\bar{u} u=2 \mathrm{~m}$. The mathematical object $S$ is the classical Hamilton-Jacobi function, which was determined in the form:

$$
S=-p x-\int_{0}^{k x} \frac{e}{(k p)}\left[(p A)-\frac{e}{2} A^{2}\right] d \varphi .
$$

The current density is

$$
j^{\mu}=\bar{\psi}_{p} \gamma^{\mu} \psi_{p}
$$

where $\bar{\Psi}$ is defined as the transposition of (44), or,

$$
\bar{\psi}_{p}=\frac{\bar{u}}{\sqrt{2 p_{0}}}\left[1+\frac{e}{2 k p}(\gamma A)(\gamma k)\right] e^{-i S} .
$$

After insertion of $\Psi_{p}$ and $\bar{\Psi}_{p}$ into the current density, we have:

$$
j^{\mu}=\frac{1}{p_{0}}\left\{p^{\mu}-e A^{\mu}+k^{\mu}\left(\frac{e(p A)}{(k p)}-\frac{e^{2} A^{2}}{2(k p)}\right)\right\} .
$$




\section{Index of refraction from the Volkov solution of the Dirac equation}

Let be $\psi_{a}$ the wave function of the electron in the vector field potential in an atom (a) $A_{a}$, and $\Psi_{w}$ the wave function of the electron in the plane wave (w) potential $A_{w}$. The corresponding Dirac equations of these two situations are as follows:

$$
\begin{aligned}
& \left(\gamma\left(p-e A_{a}\right)-m\right) \psi_{a}=0 . \\
& \left(\gamma\left(p-e A_{v}\right)-m\right) \psi_{w}=0 .
\end{aligned}
$$

If we take the sum of eqs. (50) and (51), we get

$$
\left(\gamma\left(p-e A_{a}\right)\right) \psi_{a}+\left(\gamma\left(p-e A_{w}\right)\right) \psi_{w}=m\left(\psi_{a}+\psi_{w}\right)
$$

which is not equation of the total system with potentials $A_{a}+A_{w}$.

It may be easy to see that the Dirac equation for the sum $\psi_{a}+\psi_{w}$ is the following equation:

$$
\left(\gamma\left(p-e\left(A_{a}+A_{w}\right)\right)\left(\psi_{a}+\psi_{w}\right)=m\left(\psi_{a}+\psi_{w}\right)-A_{a} \psi_{w}-A_{w} \psi_{a},\right.
$$

or, wave function $\left(\psi_{a}+\psi_{w}\right)$ is not solution of the Dirac equation for the complex system $\left(A_{a}+A_{w}\right)$.

Nevertheless, we can use the wave function $\psi=\psi_{a}+\psi_{v}$ as the first approximation in determinantion of the index of refraction for the system, which is in the potential $A_{a}$ and in the wave potential $A_{v}$.

With regard to eq. (26), we write for the polarization

$$
\mathbf{P}=N e \int \bar{\psi} \mathbf{x} \psi=\frac{n^{2}-1}{4 \pi} \mathbf{E}=\frac{n^{2}-1}{4 \pi}\left\{-\frac{1}{c} \frac{\partial \mathbf{A}}{\partial t}-\operatorname{grad} \varphi\right\},
$$

where we used the definition of $\mathbf{E}$ according to the Landau et al. textbook (Landau et al., 1988).

So, we get the original formula for the intex of refraction of medium in case the signal propagatiin throught the medium is the plane wave:

$$
\frac{n^{2}-1}{4 \pi}=\frac{N e \int \bar{\psi} \mathbf{x} \psi}{-\frac{1}{c} \frac{\partial \mathbf{A}}{\partial t}-\operatorname{grad} \varphi}
$$

where $\psi=\psi_{a}+\psi_{w}$.

\section{Discussion}

The last formula (55) is original and it is not excluded that it will play the crucial role in modern optics. It is possible expect the application of it in the graphene physics (Novoselov et al., 2005) where every new result in quantum optics is valuable. At the same time we hope that the derived formula will be tested by the greatist laser system over the world, called ELI. 
The article is related also to the pair production by the Cerenkov process. Pair production is the creation of a particle and its antiparticle from a neutral boson. Examples are - creating an electron and a positron, a muon and an antimuon, a proton and an antiproton and so on. In order for pair production to occur, the incoming energy of the interaction must be abovet he total rest mass energy of the two particles. Both energy and momentum are conserved. However, all other conserved quantum numbers (angular momentum, electric charge, lepton number) of the produced particles must sum to zero.

The Čerenkov radiation is emitted by motion of fast charged particle in a medium when its speed is faster than the speed of light in this medium This effect was observed experimentally first by Cerenkov $(1934 ; 1936)$ and theoretically interpreted by Frank and Tamm (1937) in the framework of the of the clasical electrodynamics. The modern field theory explanation was given by Schwinger et al. (1976) and the particle production by the Cerenkov mechanism including temperature was discussed by Pardy (1983a; 1983b; 1989; 1994; 2002) and experts in particle physics.

The spectrum of radiation is modified involving the radiation correction in the photon propagator (Pardy, 1994). The experimental value for pair creation is (Pardy, 1994) for

$$
\omega^{2}>\frac{4 m^{2} c^{2} v^{2}}{\hbar^{2}\left(n^{2} \beta^{2}-1\right)}
$$

It means that for $n=\sqrt{2}$ and $v \approx c$, we get from eq. (56) $\hbar \omega \approx 2 m c^{2}$, which can be interpreted as the condition for creation of the electron-positron pair by the gamma quantum.

The condition (56) is related to the gamma photons rather than to the optical ones. The possibility of the existence of the gamma Cerenkov radiation is discussed by Ion and Stocker (1993) in nuclear physics. The so called nuclear gamma Čerenkov radiation requires a special experimental technique in order to extract such radiation from the background produced by other mechanism. Such techniques are well known in nuclear physics and we can expect that sooner or later the existence of the gamma Cerenkov radiation in nuclear physics will be confirmed together with the pair production.

The present theory can be generalized to the the string-like objects (Manoukian, 1991; 1992) where the problems of particle production by strings are discussed.

\section{REFERENCES}

Berestetzkii, V. B.; Lifshitz, E. M. and Pitaevskii, L. P. Quantum electrodynamics, (Moscow, Nauka, 1989). (in Russian).

Cerenkov. P. A. (1934). The visible radiation of pure liquids caused by $\gamma$-rays, Comptes Rendus Hebdomaclaires des Séances de l'Académie des Sciences USSR 2, 451.

Čerenkov, P. A. (1936). Visible Radiation Produced by Electrons Moving in a Medium with Velocities Exceeding that of Ligh C. R. Acad. Sci. (USSR) 3, 413. 
Ion, D. B. and Stocker, W. (1993). High-energy nuclear $\gamma$-Cherenkov radiation, Phys. Lett. B 311,339 .

Ladenburg, R. (1921). Die quantentheoretische Bedeutung der Zahl der Dispersionelektronen, Zeitschrift für Physik, 4, No. 4, 451-468 (1921).

Ladenburg, . and Levy, S. (1930). Untersuchungen ber die anomale Dispersion angeregter Gase VI. Teil: Kontrollversuche für den Nachweis der negativen Dispersion: Absorption, anomale Dispersion, Intensittsverteilung und Intensität verschiedener Neonlinien, Zeitschrift für Physik, 65, Nos. 3-4. pp. 189-206.

Landau, L. D. and Lifshitz, E. M., The classical theory of fields, 7th ed., (Moscow, Nauka, 1988), (in Russian).

Manoukian, E. B. (1991). Electromagnetic radiation from a Nambu string at finite temperatures, Nuovo Cimento 104 A, No. 9, 1409.

Manoukian, E. B. (1992). $e e^{+}$Production by a Nambu string, International Journal of Theoretical Physics 31, No. 6, 1003.

Marci, J. M. (Johannes Marcus Marci de Cronland), (1668). De arcu coelesti, (Charles University, Prague)

Newton, I. (1998). Opticks: or, a treatise of the reflexions, refractions, inflexions and colours of light. Also two treatises of the species and magnitude of curvilinear figures. Commentary by Nicholas Humez (Octavo ed.). Palo Alto, Calif.: (Opticks was originally published in 1704).

Novoselov, K.S.; Geim, A. K.; Morozov, S.V. et al. (2005). Two-dimensional gas of massless Dirac fermions in graphene, Nature, 438, 197.

Pardy, M. (1983a). Particle production by the Čerenkov mechanism, Phys. Lett. 94 A, 30.

Pardy, M. (1983b). Particle production by accelerated charges moving in condensed matter, Journal of Phys. G: Nucl. Phys. 9853.

Pardy, M. (1989). Finite temperature Čerenkov radiation, Phys. Lett. A 134, No. 6, 357.

Pardy, M. (1994). The Čerenkov effect with radiative corrections, Phys. Lett. B 325, 517.

Pardy, M. (2002). Čerenkov effect with massive photons, Int. Journal of Theoretical Physics 41 No. 5,887 .

Sokolov, A. A.; Loskutov, Yu. M. and Ternov, I.M. Quantum mechanics, (Moscow , 1962). (in Russian).

Schwinger, J., Tsai, W. Y. and Erber, T. (1976). Classical and quantum theory of synergic synchrotron-Čerenkov radiation, Annals of Physics (NY) 96, 303.

Tamm, I. E. and Frank, I. M. (1937). The coherent radiation of a fast electron in a medium, Dokl. Akad. Nauk SSSR 14, 109. 


\title{
Low Inductive and Resistance Energy Capacitor Alexander Bolonkin

\author{
abolonkin@gmail.com
}

\begin{abstract}
The paper considers the design of a powerful electric capacitor with a very small induction and resistance. Such capacitors are necessary in many branches of technology, when all the energy of a capacitor must be given out for millionths $\left(10^{-6}\right)$ of a second to an object with low electrical resistance.

The proposed capacitor allows you to reduce the installation of energy supply to a nuclear reactor and its cost a thousand times.

Keywords: Low Inductive Capacitor, Low Resistance Capacitor, Energy Capacitor, Capacitor for Fusion Reactor.

\section{Introduction}

In the middle of the last century, there was a need for considerable storage of energy (radar, lasers, nuclear power, etc.) capable of delivering this energy in millionths of a second. Naturally, scientists turned to powerful capacitors. But it turned out to give all the energy to an object with a small electrical resistance in a short time is not so simple. The energy of the simplest triangular pulse is

$$
E=0.5 I U t
$$

where $E$ is energy, $\mathrm{J} ; I$ - electric current, A; $U$ - voltage, $\mathrm{V} ; t$ - time, sec.

If you try to give a small energy of $50 \mathrm{~kJ}$ even at a high voltage of 100 thousand volts per 0.1 micro seconds, then a giant current pulse $I=2 E / U t=100 /(100 \times 0.0000001)=10$ million amperes will occur, which will create a giant magnetic field. This field will inhibit the transfer of energy to the object, return energy back to capacitor. Begin fluctuations in voltage and current, the loss of energy in the wires. The transmission time will increase many times and only a small fraction of the energy will reach the object. Wires and contacts may burn out. That is why scientists began to invent schemes that would help circumvent this obstacle. One of the latest structures was the Linear Transformer Driver (LTD) - a giant installation with a diameter of 120 meters, a height of three floors and a cost of more than 300 million (Fig. 1). Installation is built in Sandia National Laboratories (USA) and used Z-machine. But Z-machine is not reaching the stable nuclear energy more than it is spending.
\end{abstract}

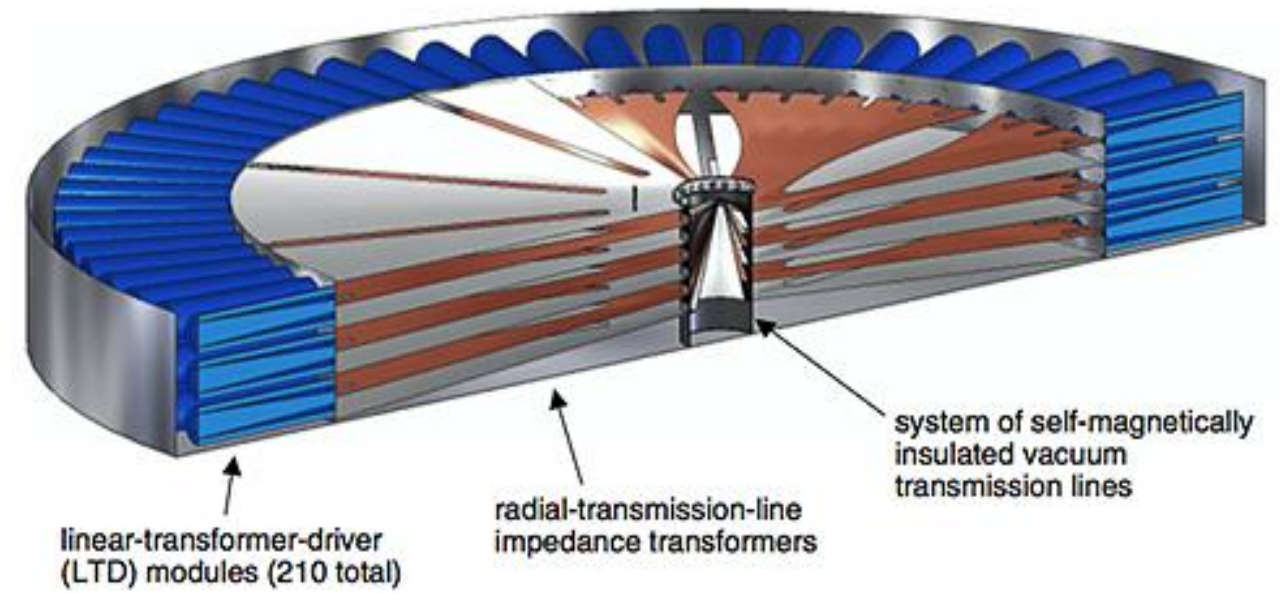

Fig.1. (LTD) - Linear Transformer Driver. Installation for compressing and transfer energy from capacitors to nuclear capsule. Human being (the black line just left of the center of the LTD) for scale. 
The purpose of this article is to propose a new capacitor and show that a new capacitor design can significantly reduce the internal inductance and electrical resistance of a powerful power capacitor, shorten the pulse time, protect the internal wires and capacitor contacts from giant current pulses. And most importantly reduce the size and cost of installation thousands of times.

\section{Description of the installation}

The entire design of the proposed capacitor is subject to the same goal - to reduce the discharge time of the capacitor, bring it to at least $0.1 \div 0.5$ micro seconds and transfer a significant part of this energy to the desired object. Such an object can be, for example, a very small capsule with a nuclear fuel of an inertial thermonuclear reactor, which must be heated to 100 million degrees $(10 \mathrm{keV})$, in order to start a confident thermonuclear reaction. Short transmission time is dictated by the requirement of inertia. With a large heating time the capsule will scatter and the thermonuclear reaction will not start.

The time of the issuance of energy by the capacitor is equal to

$$
t=0.5 \pi \sqrt{ } C L
$$

where $t$ is time, sec; $\mathrm{C}$ is capacity of capacitor, $\mathrm{F} ; L$ is an inductance of installation, $\mathrm{H}$.

Since the energy is given, we can only influence the inductance. But the required short discharge time leads to the fact that the current pulse becomes very large - millions of amperes, which can lead to the burning of conductors, contacts and capacitor. In the case of a single pulse, it is not terrible if the cross section of the conductors and contacts is large, because the energy of the capacitor is limited. For example, if the energy of the capacitor is $50 \mathrm{~kJ}$, the transverse conductors of the system are $10 \mathrm{~cm}^{2}$ and $400 \mathrm{~cm}$ long, then when the capacitor is short-circuited, the heating of the copper conductors from a single pulse is about 0.5 degrees, about 7 degrees aluminum.

It is very important that the capacitor energy goes to heat the plasma in the capsule, and not to heat the capacitor, the system conductors (including the wires in the capacitor), the external conductors of the system, the switch, the contacts, and the capsule case.

The ratio $r / R$ has a significant influence on the distribution of energy, where $r$ is the resistance of the capsule and $R$ is the ohmic resistance of the entire system. This ratio shows what proportion of the energy of the capacitor can reach the capsule.

Thus, we see that the only means to quickly discharge a capacitor with a given capsule and the energy of a capacitor is to reduce the inductance and resistance of the system. Otherwise, a large proportion of the energy will go to heating the system and creating a powerful magnetic field. True energy of the internal magnetic field does not disappear. It returns in the form of reverse current and voltage after discharge of the capacitor. But in the inertial reactor it is difficult to use, because the opposite voltage inhibits accelerated fuel cores, i.e. reduces temperature and the likelihood of a thermonuclear reaction.

The inductance of the system can be significantly reduced by arranging the conductors of the forward and reverse currents in the capacitor and the system so that they are as close as possible and have the same opposite current. Then they will create opposite fields and strongly weaken the total magnetic field, i.e. reduce the energy in it. The main magnetic field will be between them. This space should be made minimal. But the conductors are charged in the opposite way and the distance between them is determined by the breakdown ability of the insulator and the configuration of the conductors.

Figure 2a shows two wires (direct and reverse), located side by side to reduce inductance. The minimum distance between them is determined by the penetrating ability of the medium (insulator) in which they are located. Another form of such configurations is a coaxial cable, shown in fig. 2b. It consists of a central wire, insulation and external conductive sheath. Used for protection against radio interference. 

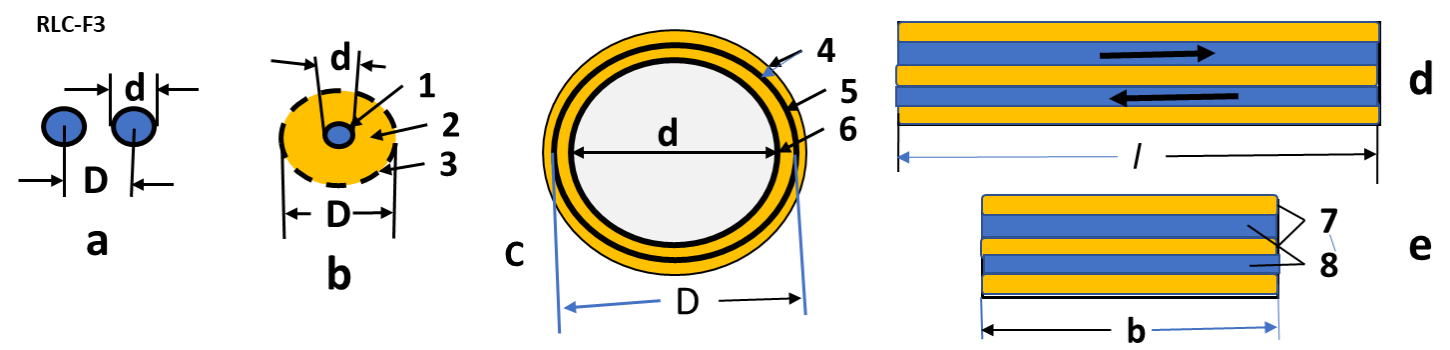

Fig. 2. Cross-sections of conductors for the delivery of electrical energy to the consumer. Legend: a - two round conductor, located alongside; b - coaxial cable: 1 - center wire, 2 - insulator, 3 - surface wire (fly-through); c - coaxial cylinders: 4 - insulator, 5 - outer cylinder, 6 - inner cylinder; e, d - two lanes located one above the other at the minimum distance: 7 - insulator, 8 - conductive strips, $l$ - long strip, $b$ - strip width.

The author proposes the other two configurations with low inductance (Fig. 2c). One of them is two isolated conductive cylinders located one in another. The other is two molded conductive strips, one above the other. With the right construction, both solutions $(c, d)$ give better results on inductance than the known solutions $(\mathrm{a}, \mathrm{b})$.

Reducing the electrical resistance of a system (without a capsule) can be done quite simply - by increasing the cross sections of the conductors. This requires the creation of new capacitors. Powerful capacitors with low inductance are also not produced even by US factories, since before they were not required by industry. Manufacturers can only offer a parallel connection of capacitors, which reduces the inductance of a capacitor bank (reduces the magnetic field energy by reducing the current in individual capacitors when connected in parallel), but increases the inductance of external connections.

Estimates show that the required power capacitor can measure $1.1 \times 1.1 \times 1.6 \mathrm{~m}$ and weigh about 2.5 tons.

Note that the abandonment of huge, very expensive LTD structures and their replacement with capacitors with the correct design can reduce the cost of installing energy delivery to a nuclear capsule by a factor of about a thousand.

Designing a capsule for such a reactor is also not an easy task. This is not Ohm's task. Plasma resistance is strongly dependent on its temperature. The voltage applied to it causes the collective acceleration of separately positive and negative particles in opposite directions. They freely pass between them and strike the electrodes by heating them, causing X-ray and bremsstrahlung. This task will be considered by the author in other papers.

\section{The theory of the proposed energy transfer.}

The theory of radar (discharge of a capacitor) is used for the calculation with the difference that the electrical resistance is variable, since the specific electrical resistance of the plasma is very dependent on its temperature, and the temperature strictly depends on the energy received.

The electrical circuit for discharging a capacitor is shown in Fig. 3. Please note that for our design of the capsule $L$ and $R 1$ we consider constant, $R 2$ is the resistance of the capsule variable, and the inductance of the capsule is so small that it can be neglected.

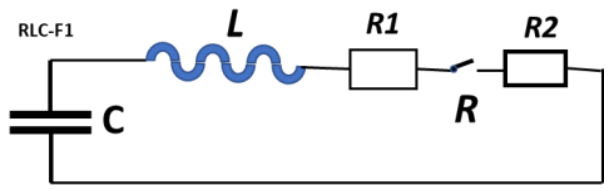

Fig.3. The schematic diagram of our installation. Notation: $C$ is capacitor, $L$ is Internal inductance of capacitor 
and external wiring; $R 1$ is Internal resistance of the capacitor and external wiring; $R 2$ is resistance of the fusion fuel capsule; $R=R 1+R 2(t)$.

\section{Calculated formulas}

The main well-known calculation formulas and some calculation results for a capacitor having a voltage of $V=100 \mathrm{kV}$, energy $E=50 \mathrm{~kJ}$ are given below.

The initial voltage capacitor is $U(0)=100 \mathrm{kV}$, energy is $E(0)=50 \mathrm{~kJ}$ :

$$
\begin{array}{r}
E=0.5 C U^{2} k J, C=\frac{2 E}{U^{2}}=\frac{2 \times 50}{100^{2}}=10^{-5} \mathrm{~F}, \\
\text { where } C \text { is capacity of condenser, } \mathrm{F} . \\
\text { Charge of capacitor is: } \\
q=\frac{2 E}{U}[C] . \quad
\end{array}
$$$$
\text { Capacity of plat capacitor is: }
$$

$$
C=\frac{\varepsilon_{o} \varepsilon S}{a},
$$

where $\varepsilon_{o}=8.85 \cdot 10^{-11} \mathrm{~F} / \mathrm{m}$ - electric constant; $\varepsilon$ is dielectric constant of isolator, $S$ is capacitor area, sq. $\mathrm{m} ; a$ is distance between sheets, $\mathrm{m}$.

Differential equations of discharging the capacitor is [4] p. 450:

$$
r i-U=-L \frac{d i}{d t}, \quad U=\frac{q}{C}, i=-\frac{d q}{d t} \text {. }
$$

where $r$ is electric resistance, Ohm; $i$ is electric current, A; $L$ is induction, $\mathrm{H} ; t$ is time, sec.

This system we can re-write as one equation of the second order:

$$
L \frac{d^{2} q}{d t^{2}}+\mathrm{r} \frac{d q}{d t}+\frac{q}{C}=0 \text { or } \frac{d^{2} q}{d t^{2}}+2 \alpha \frac{d q}{d t}+\omega_{o}^{2} q=0
$$

Where

$$
\alpha=\frac{r}{2 L}, \omega_{o}^{2}=\frac{1}{L C} .
$$

Electric resistance of wire is:

$$
R 1=\rho \frac{l}{s},
$$

Here $\rho$ is specific resistance, $\Omega . \mathrm{cm}$ (for copper $\rho=1.75 \times 10^{-6}, \Omega . \mathrm{cm}$ ); $l$ is wire length, $\mathrm{cm}$; $s$ is cross section of wire, sq. sm.

Spitzer resistance of plasma is:

$$
R 2=\eta \frac{l}{s} \text { where } \eta=\frac{o .1 Z}{T^{-3 / 2}},
$$

Here $Z$ is charge of nuclear fuel: for nuclear fuel $\mathrm{T}+\mathrm{D}, \mathrm{D}+\mathrm{D} Z=1 ; T$ is plasma temperature in $\mathrm{eV}$.

$$
1 \mathrm{eV}=1.6 \cdot 10^{-19} \text { J. } 1 \mathrm{eV}=11,604 \mathrm{~K} \text {. }
$$

A typical curve for charging and discharging a capacitor $V=V(t)$ is shown in Fig. 4.

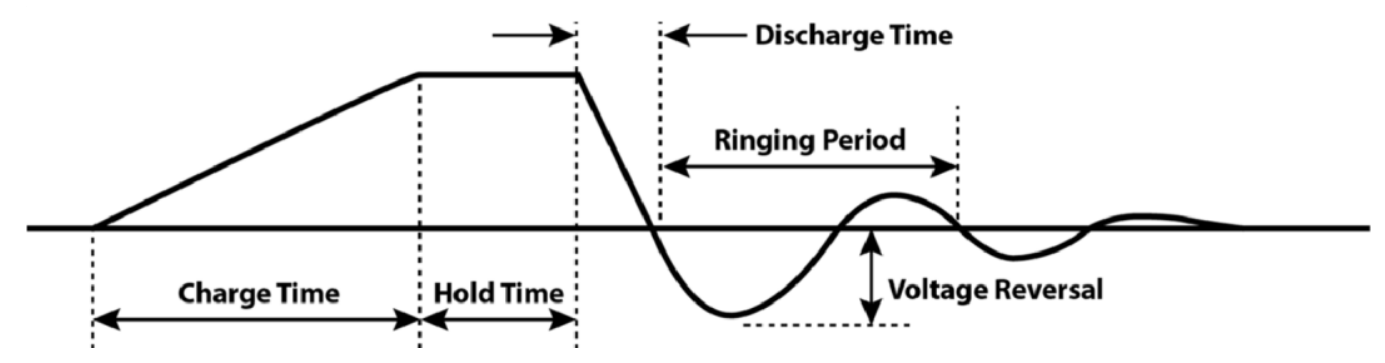

Fig.4. A typical curve for charging and discharging a capacitor $V=V(t)$, where $V$ is voltage, V. 
A useful parameter is the damping factor, $\zeta$, which is defined as the ratio of these two; although, sometimes $\alpha$ is referred to as the damping factor and $\zeta$ is not used.

$$
\zeta=\frac{\alpha}{\omega_{0}}
$$

In the case of the series RLC circuit, the damping factor is given by

$$
\zeta=\frac{R}{2} \sqrt{\frac{C}{L}}
$$

The value of the damping factor determines the type of transient that the circuit will exhibit.

\section{Transient response}

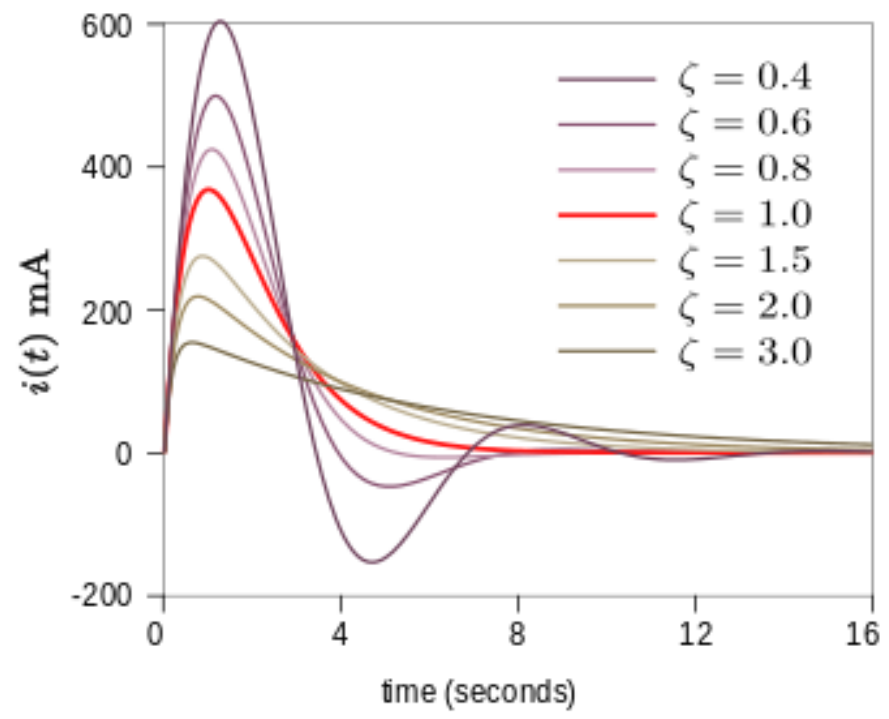

Fig.5. Influence of damping factor in the discharge curve. Plot showing underdamped and overdamped responses of a series RLC circuit. The critical damping plot is the bold red curve. The plots are normalized for $L=1, C=1$ and $\omega_{0}=1$.

The differential equation for the circuit solves in three different ways depending on the value of $\zeta$ (Fig.5). These are underdamped $(\zeta<1)$, overdamped $(\zeta>1)$ and critically damped $(\zeta=1)$. The differential equation has the characteristic equation [5].

\section{Estimation of inductivity and electric resistance.}

The inductivity of different wires design which are shown in Fig.2 may be estimated by equations:

1. Two round column/wires (Fig. 2a):

$L=\frac{\mu_{o} l}{\pi}\left(\frac{1}{2}+\ln \frac{D}{0.5 d}\right)$.

Here $\mu_{o}=4 \pi 10^{-7}$ - magnetic constant, H/m; $l$ - length of tape, $\mathrm{m}$. In conventional 
capacitor the insulated long foil tape rolls into a roll. This simplifies production, but greatly increases the inductance.

2. Coaxial cable (Fig.2b).

$$
L=\frac{\mu_{o} l}{\pi} \ln \frac{D}{d} \text {. }
$$

This design decreases the inductivity and protect radio lines from interference. 3. Big cylinder into cylinder (Fig.2c). This design offers the author.

$$
L=\frac{\mu_{o} l}{\pi} \ln \frac{D}{d}=\frac{\mu_{o} l}{\pi} \ln \frac{r+\delta}{r} \text {. }
$$

Here $r$ is radius small cylinder, $\mathrm{m} ; \delta$ is thickness of isolator, $\mathrm{m}$.

For $\delta<r$ the equation (13) we can re-write in form:

$$
L \approx \frac{\mu_{o} l}{\pi} \frac{\delta}{r} \text {. }
$$

For big $r$ the ratio $\delta / r$ will be small and $L$ small.

4. Electric energy can deliver by two thin sheets having thin isolator layer between them (Fig.2d,e). If $\delta_{1}$ is the thickness of isolator, $\delta_{2}$ is the thickness of sheet and $b$ is width of the sheet, $\mathrm{m}$, for $\left(\delta_{1}+\delta_{2}\right) \ll b$, the estimation of inductivity is:

$$
L \approx \frac{\mu_{o} l}{\pi} \frac{\delta_{1}+\delta_{2}}{b} \text {. }
$$

This is not big, because the magnetic field will be only between sheets.

Example: For $l=1 \mathrm{~m}, \delta_{1}=\delta_{2}=0.004 \mathrm{~m}, b=0.5 \mathrm{~m}$, from (15) we get $L=6.4 \cdot 10^{-9} \mathrm{H}$. This value we must sum with others.

The Inductivity from thin film/folk and capsule we can neglect because thin folk connected parallel one to other, inductivity of capsule is small.

For average triangle peak of the current may be large.

Example: for energy $E=50 \mathrm{~kJ}$, time $t=10^{-6} \mathrm{sec}, V_{\text {max }}=10^{5} \mathrm{~V}$ the maximum pick current is

$$
I_{\max } \approx \frac{4 E}{V_{\text {max }}} \approx 2 M A \text {. }
$$

In our capacitor any current peak is not problem, because the heating of the capacitor depends not on the current peak, but only on the energy of the capacitor itself and the mass of conductors inside it and the correctness of the design.

Example: Let us the estimate the heating from single "shot" the capacitor having the size of the central copper conduction Fig. $7 \mathrm{~b}$. Mass of this conductor is $27 \mathrm{~kg}$. If all energy of capacitor will be spent only for heating this conductor its temperature will increases only in:

$$
\Delta T=\frac{E}{C_{p} M}=\frac{50}{7 \times 27}=0.26 \text { degree of } C .
$$

Here $C_{p} \approx 7 \mathrm{~kJ} / \mathrm{kgK}$ is heap capacity of copper. That means that we can test our capacitor in short circuit and we can measure its internal resistance of capacitor as

$$
r=\frac{U(0)}{I_{\max }},
$$

where $r$ is internal capacitor resistance, $\mathrm{Ohm} ; U(0)$ is initial voltage of capacitor, $\mathrm{V} ; I_{\text {max }}$ is maximum of current, A. If we measure the $I_{\max }$ in short circuit, we calculate the internal capacitor resistance.

The author draws attention to another problem of power capacitors with a very short pulse and a large pulse current. Inertial thermonuclear reactors are needed in very short pulse. 
This problem does not exist in conventional capacitors for ordinary industrial needs. Therefore, such a problem is not written in textbooks and many manufacturers do not know about it.

The problem is that a strong opposite current in two adjacent wires generates a very significant repulsive force. This force is used in the railgun to accelerate the projectile to hypersonic speeds.

For two round conductors, located side by side, with the opposite direction of the current, this force is equal to:

$$
F=\frac{\mu_{o} i^{2} l}{2 \pi d}
$$

where $\mu_{o}=4 \pi 10^{-7}-$ magnetic constant, $\mathrm{H} / \mathrm{m} ; i$ - current, A; $l$ - wire length, $\mathrm{m} ; d$ - distance between of wire centers, $m$.

If we take the average current $i=1 \mathrm{MA}$, wire length $l=1 \mathrm{~m}$ and $d=0.008 \mathrm{~m}$ (Fig.8b), the force is $F=2.5 \times 10^{7} \mathrm{~N} / \mathrm{m}=2.5 \times 1000 \mathrm{ton} / \mathrm{m}$.

This is gigantic force, which can destroy the contacts. They must have a special design.

Fortunately, the duration of the action is very small and the wire shift is small. If all the energy of the capacitor $E=10^{5} \mathrm{~J}$ will be spent on moving two vertical plates of Fig. $8 \mathrm{~b}$ with a force $F(19)$, then the displacement $s$ of each plate will be only

$s=E /(2 F)=1 \mathrm{~mm}$.

Such an offset can compensate for folds at the point of contact and elastic rubber rivets (3) as shown in Fig. 8c(c2).

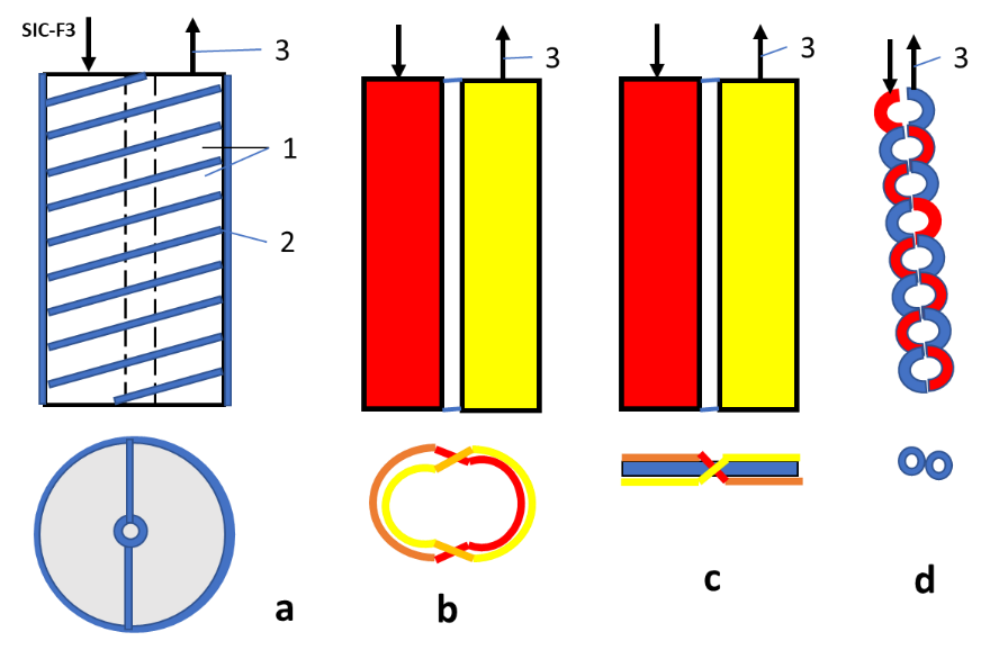

Fig.6. Reduction of inductance (reduction of magnetic fields) by interlacing conductors with equal opposite current. Legend: a - two twisted spirals, c - two intersecting cylinders, c - two intersecting planes, two twisted wires. 1 - two spirals, 2 - insulator, 3 - current direction.

\section{Example}

Small inductance capacitor having low resistance and short impulse (SIC)

We want to create the capacitor with can deliver the impulse of the energy about $30 \mathrm{~kJ}$ in a small object (the length is $<1 \mathrm{~cm}$ ) having the small electric resistance $(<0.0001 \mathrm{Ohm})$ of 
Installation in a very small time $100 \mathrm{nsec}\left(10^{-7} \mathrm{sec}, 0.0000001 \mathrm{sec}\right)$. That request the very small inductance $\left(<2 * 10^{-8} \mathrm{~Hz}\right)$, the very small electric resistance $\left(<10^{-4} \mathrm{Ohm}\right)$ of the installation and very high impulse of current (MA).

The most current capacitors not satisfy these requirements. They have inductance >

$10^{-6} \mathrm{~Hz}$ and the resistance $>0.1 \mathrm{Ohm}$. They and their contacts burn in a short circuit of capacitors.

The scientists of thermonuclear engineering try to solve this problem by the gigantic very expensive Max generators (MG) or the Linear Transformer Driver (LTD). For example, the LTD for Z-machine has diameter $120 \mathrm{~m}$ and cost the hundreds of millions of dollars (Fig.1). But the current design of MG or LTD do not alloy to get the stable or good thermonuclear reaction.

Attention! This material is not a detailed instruction for construction SIC. Only the IDEA of such a condenser is stated here. It is supposed that an experienced creative engineer (or group) will make detailed drawings and computed parameters (Bolonkin A.A., Low Inductive and Resistance Energy Capacitors): Initial data are: Voltage $U=100 \mathrm{kV}$, capacity $C=10^{-5} \mathrm{~F}$, energy $E=50 \mathrm{~kJ}$. Final data: Inductance $L<2 \times 10^{-8} \mathrm{~Hz}$, resistance $<10^{-4} \mathrm{Ohm}$, discharge time about $<4 \times 10^{-7} \mathrm{sec}$, heating of object is $>10 \mathrm{keV}$.

It is desirable that the developer pre-agreed their drawings and data with the author Alexander Bolonkin (<abolonkin@gmail.com>).

For example, any patent lays out only the idea of innovation, placing the detailed design and manufacturing on the user of the invention.

\section{Short description of problem.}

The schematic diagram of our installation is shown in Fig. 3. Here: $C$ is capacitor, $L$ is Internal inductance of capacitor and external wiring; $R l$ is Internal resistance of the capacitor and external wiring; $R 2$ is resistance of the fusion fuel capsule; $R=R 1+R 2$.

Our goal is to heat 0.0001 grams of fuel to a temperature of $10 \mathrm{keV}$. To do this, we have to deliver $30 \mathrm{~kJ}$ of energy to the capsule fuel from $50 \mathrm{~kJ}$ of energy, that is in the capacitor, ASAP $\left(<4 \times 10^{-7} \mathrm{sec}\right)$. Otherwise, the capsule will have time to explode, expand, and the ignition of thermonuclear fuel will not occur.

The schematic diagram of our installation is sown in Fig. 3.

A typical curve for charging and discharging a capacitor is shown in Fig.4.

We are satisfied with the data:

Charge time about $10 \mathrm{~min}$ (now) and $1 \mathrm{sec}$ (in future).

Hold time about 1 - 5 min.

Discharge Time $4 \times 10^{-7} \mathrm{sec}$.

Ringing Period - any now.

Voltage Reversal $<10 \div 20 \%$.

Author offers new innovation design of the capacitor which allow to get the need requirements and alloy to have any single impulse of the electric current. 
He reaches these by:

1) The opposed closed currents which create the opposed magnetic fields. These fields neutralize each other and spend little energy on their creation. These made in main sheets and all wiles.

2) All wires are made in the form of wide strips with the opposite direction of the currents and with a minimum distance between them.

3) The capacitor is divided into the maximum number of individual parallel films/plates with alternating current directions.

4) Special low-ohm strip contacts of the thin films to the main plates with the main wiring are made.

5) Wiring has a small equal resistance everywhere except for two cuts and the contact area of the plates in the output wire.

6) The mass and thickness of the plates of wires is sufficiently for the permissible heating.

Conventional capacitors are made of a long-insulated tape rolled into a roll (Fig. 7a).

The proposed capacitor is made from a set of insulated thin plates/films. These plates have a special arrangement and a separate connection with special central leads/sheets.

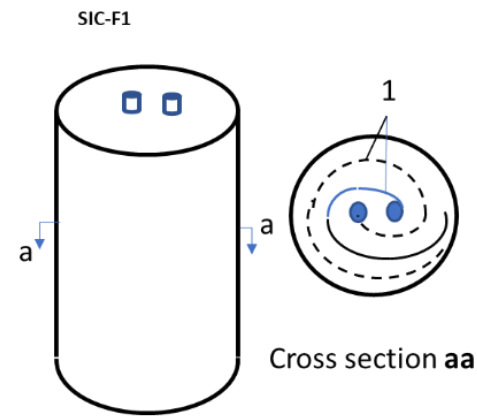

a. Conventional capacitor
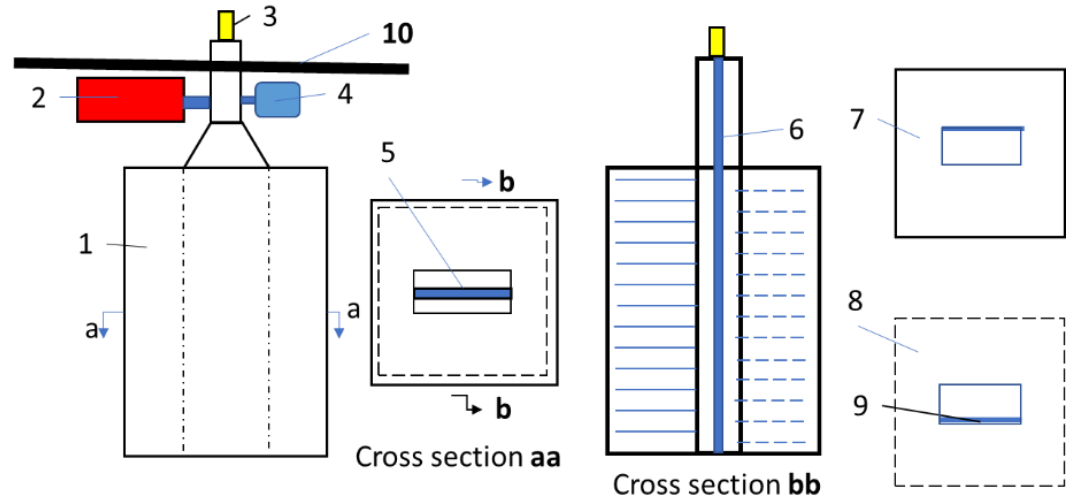

b. Offer small inductance capacitor

Fig.7. Conventional and offered capacitor. Notifications: a-conventional capacitor. 1- a long insulated tape rolled into a roll; $\mathbf{b}$ - proposed small inductance capacitor. Capacitor is made from a set of insulated thin plates: 1 - capacitor, 2 -high voltage switch, 3 - connection to variable object, 4 - charger, 5 insulator between main exit/enter plates; 6 - insulator of the main plate; 7 - the first thin film, 8 - the second thin film, connection film, 9 - the second thin film, 10 - steel plate $(10 \mathrm{~mm})$, which separate the capacitor, high voltage switch and charger from an explosive area.

\section{Estimation. Example of the proposed Installation}

Recommended (computed) sizes, thickness and material (electric engineers and designers can offer the better):

Voltage $U=100 \mathrm{kV}$, capacity $C=10^{-8} \mathrm{~F}$, energy $E=50 \mathrm{~kJ}$, discharge time $t<4 \times 10^{-7}$ sec. 


\section{Offered material:}

1) Electric copper for the thin film and main plate. Data: specific electric resistance $\rho=1.7 \times 10^{-6} \mathrm{Ohm} . \mathrm{cm}$; specific mass $\gamma=8.91 \mathrm{gr} / \mathrm{cm}^{3}$; Heat capacity $C p=1.99 \mathrm{~kJ} / \mathrm{kg} \cdot \mathrm{K}$.

2) Isolator PTFE. Teflon $\left(\mathrm{C}_{2} \mathrm{~F}_{4}\right)_{\mathrm{n}}$ : dielectric strength $(1 \mathrm{MHz}) 60 \div 173 \mathrm{MV} / \mathrm{m} ; \varepsilon=2.1$; specific electric resistance $\rho=1 \times 10^{23} \div 1 \times 10^{25} \mathrm{Ohm} \cdot \mathrm{m}$; specific mass $\gamma=2200 \mathrm{~kg} / \mathrm{m}^{3}$; yield strength 23 $\mathrm{MPa}$, melting temperature is $327^{\circ} \mathrm{C}$.

Computed parameters (see theory and computation in given article Bolonkin A.A., Low Inductive and Resistance Energy Capacitor): Inductive of installation is $<2 \times 10-8 \mathrm{~Hz}$, resistance $<10^{-4} \mathrm{Ohm}$, discharge time about $<4 \times 10^{-7} \mathrm{sec}$, heating of object is about $10 \mathrm{keV}$.

Requested area of thin film for capacitor is:

$$
S=\frac{C d}{\varepsilon_{o} \varepsilon}=215 \mathrm{sq} . \mathrm{m}
$$

where $S$ - area of capacitor, $\mathrm{m}^{2} ; C=10^{-5}$ - capacity of capacitor, $\mathrm{F} ; d=4 \mathrm{~mm}$ - thickness of isolator, $\mathrm{m} ; \varepsilon_{o}=8.85 \times 10^{-11} \mathrm{~F} / \mathrm{m}-$ electric constant; $\varepsilon=2.1-$ dielectric constant of Teflon.

This area requests about 215 thin copper film/foil $\mathbf{1 0 5} \times 105 \mathrm{~cm}$ (or 430 copper film $57.5 \mathrm{x}$ $105 \mathrm{~cm}$ ) and > 216 the $110 \times 110 \mathrm{~cm}$ sheets of Teflon having the thickness $4 \mathrm{~mm}$.

Size (option) of the capacitor/installation box is about 120x120x120 cm. Mass is about 3.5 tons. Average $R 2 \approx 5 \times 10 e-3 \mathrm{Ohm}$. $\left(R 2<5 \cdot 10^{-3} \Omega\right)$.

Let us estimate the thickness of the coper thin film/foil and main plate. If we take the cross section area of internal wires $20 \mathrm{sq} . \mathrm{cm}$ and width of main sheet is $50 \mathrm{~cm}$, then thickness if the thin film will be about $\mathbf{0 . 2 5} \mathbf{~ m m}$ and main sheet is about $\mathbf{4} \mathbf{~ m m}$, the $R l \approx$ $0.0001 \mathrm{Ohm}, L \approx 2 \times 10 e-8 \mathrm{~Hz}\left(2 \cdot 10^{-8}\right)$, time of "shot" $\Delta t=10 e-6 \mathrm{sec} .\left(<10^{-6}\right)$. The heating of main sheets is about $\mathbf{0 . 2}^{\circ} \mathbf{C}$ after "shot". Connection 3 (Fig.8) must be checkup in tensile stress because the strong impulse current will try disconnect them. That may reach hundreds $\mathrm{kg}$.

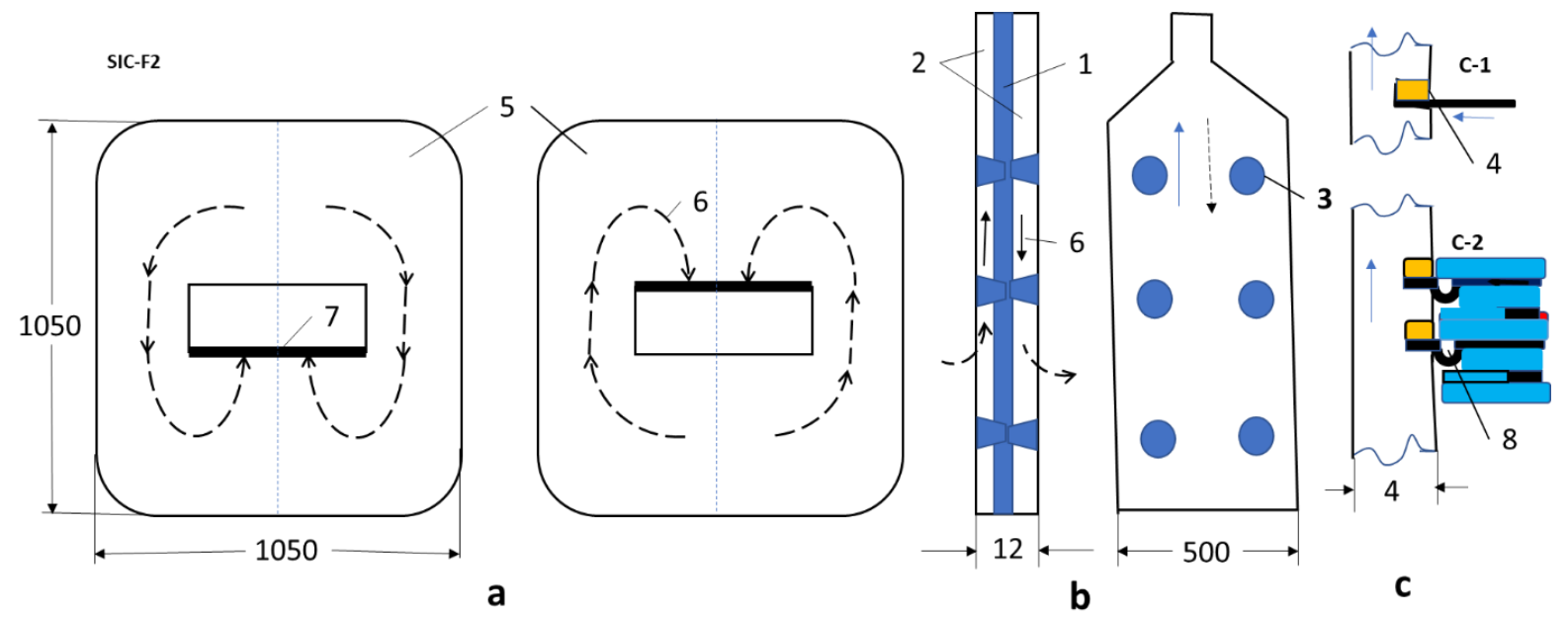

Fig.8. Direction of current in the first and second thin films (a) and main plates (b). (c) - connection the thin films to the main plates. Notification: 1 - insulator; 2 - insulator of the main plate, insulator between thin film/foil has form "a"; 3 - connection main plates by insulator; 4 (c1, c2) - connection (by copper) thin film and main plate; 5 - thin films; 6 - direction of current; 7 - connection thin film to main plate; 8 - compensation of the thin film. 
Selected initial data are not optimal. Creative electric engineer can offer and recalculate the better version. I think the thin film $145 \times 145 \mathrm{~cm} \approx 2 s q . m$ decrease the capacitor height up $80 \mathrm{~cm}$. Decreasing the Teflon thickness from $4 \mathrm{~mm}$ to $3 \mathrm{~mm}$ decreases the mass in $25 \%$. Decreasing the wire cross section to $10 \mathrm{sq} . \mathrm{cm}$ decrease the foil thickness up $0.13 \div 0.15 \mathrm{~mm}$. (Voids at the ends are filled with Teflon tape of the same thickness). Increasing of voltage can improve the main parameters of heating and time of "shot". And so on. Offered capacitor must be tested in a short circuit. Capacitor inductive and resistance must be measured.

Look also attention in the high voltage $(100 \mathrm{kV})$ switch (and charger). Switch must work very fast $\left(10^{-7} \mathrm{sec}\right)$ and have a small resistance.

\section{Some Results of Computations}

Below some results of computation, the heating of thermonuclear fuel into capsule and influence of inductive and electric resistance are presented. Assume, the volume of capsule is constant in heating, the fuel is LiD - sold crystals, mass of fuel is about 0.0001 grams.

The result of integration system differential equations (4)-(8) are below:

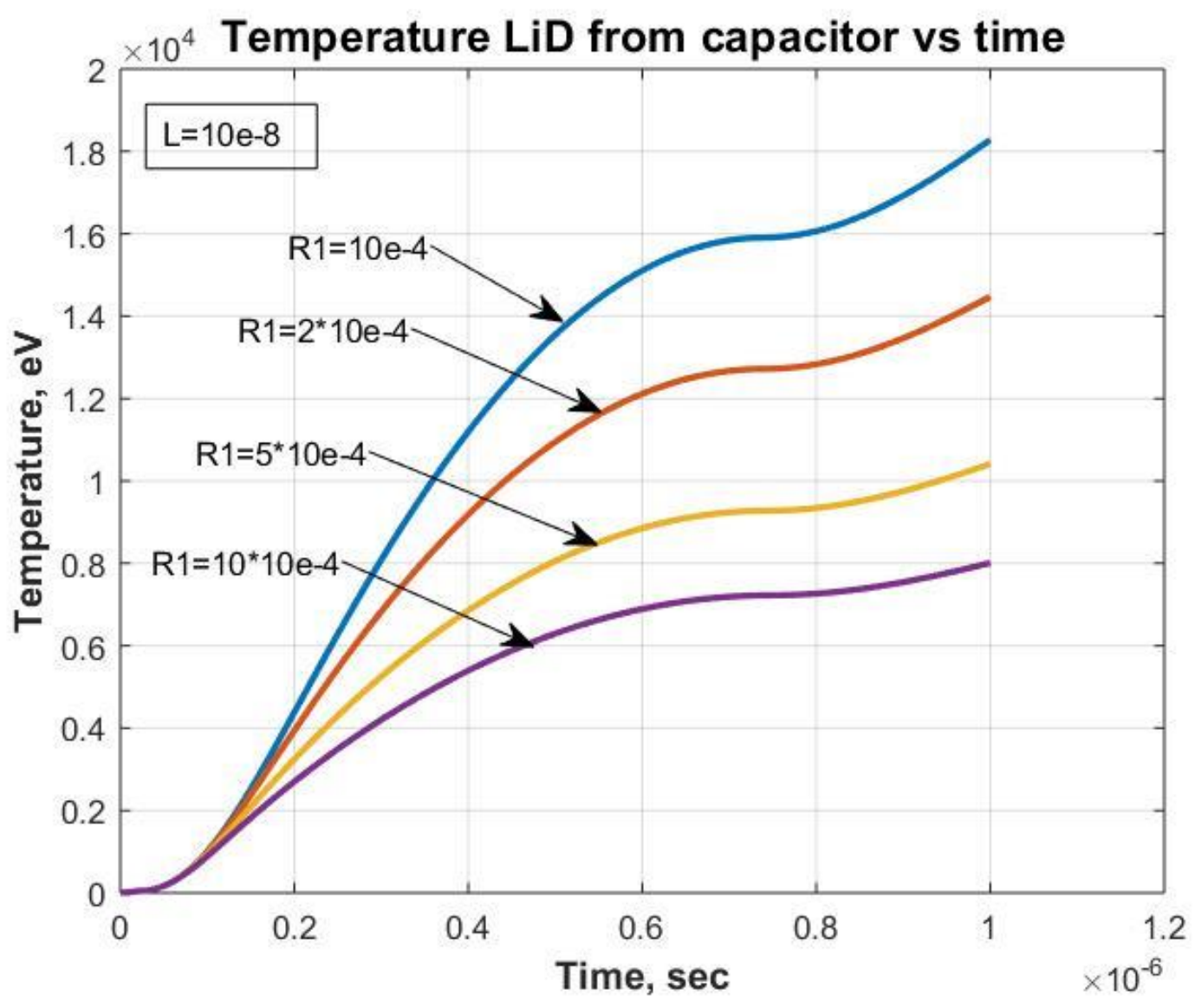

Fig.9. Temperature into capsule vs time from capacitor having $C=20 \mu \mathrm{F}, V(0)=100 \mathrm{kV}$ for induction $10^{-8} \mathrm{H}$ and different outer resistance $R_{1}=10^{-4}-10^{-3} \mathrm{Ohm}$. 


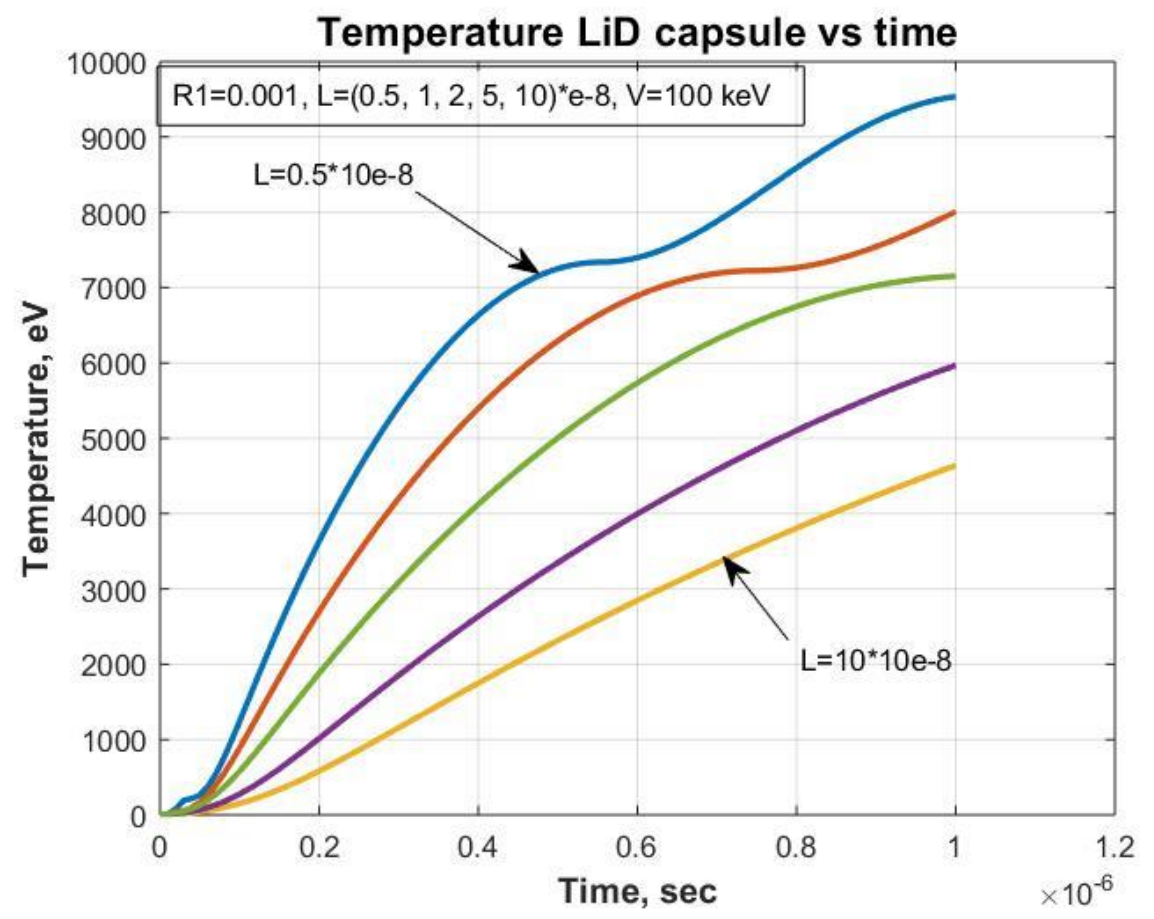

Fig.10. Temperature into capsule vs time from capacitor having $20 \mu \mathrm{F}, \mathrm{V}(0)=100 \mathrm{kV}$ for resistance $R_{1}=0.001 \mathrm{Ohm}$. and different induction $L=(0.5 \div 10) \cdot 10^{-8} \mathrm{H}$.

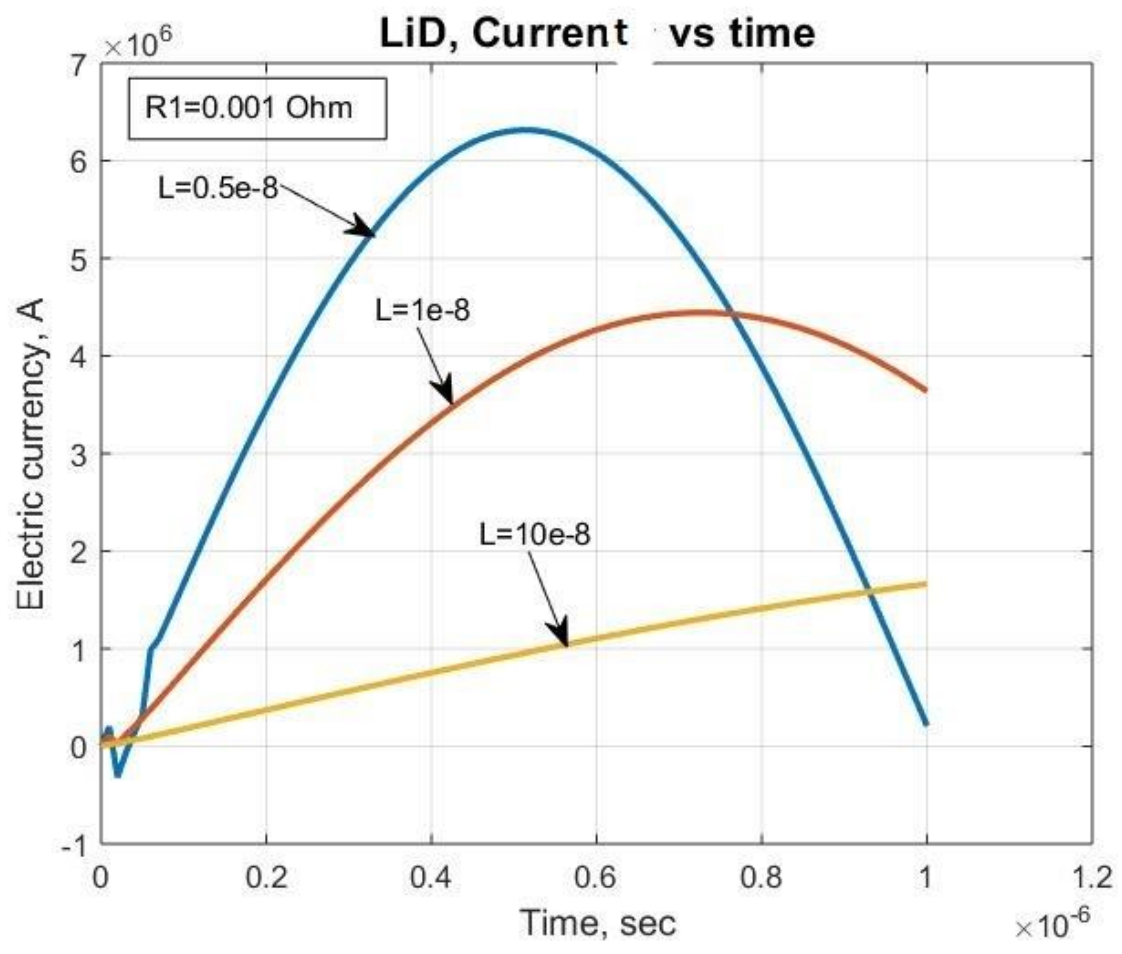

Fig.11. Electric current vs time from capacitor having $C=20 \mu \mathrm{F}, V(0)=100 \mathrm{kV}$ for resistance $R_{1}=0.001 \mathrm{Ohm}$ and different induction $L=(0.5 \div 10) \cdot 10^{-8} \mathrm{~F}$. 


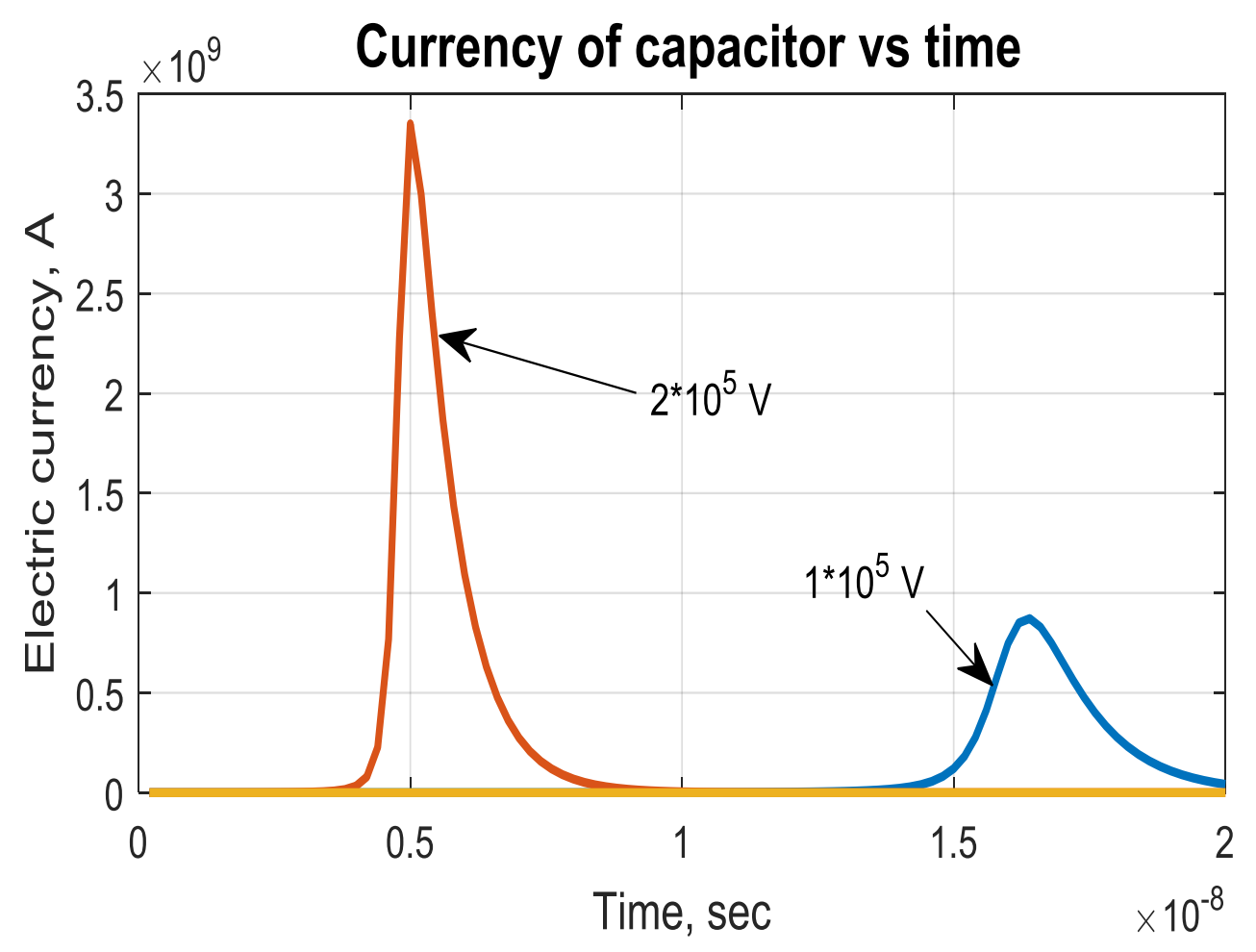

Fig.12. Peak of capacitor current vs time for initial voltage $U(0)=100 \mathrm{kV}$ and $200 \mathrm{kV}$. Capacity is $C=$ $20 \cdot 10^{-6}$ Farad. $R I=0, L=0, R 2(t)=0.1 \cdot \mathrm{Z} / \mathrm{T}(\mathrm{t})^{-3 / 2}$.

Fig.12 shows, the heat time may be decreased the maximum up $0.5 \times 10^{-8} \mathrm{sec}$, if we decrease the inductive up zero.

Description of capacitors and thermo-reactors are in [1]-[5].

\section{References}

1. Bolonkin A.A., Small non-Expensive Electric Cumulative Thermonuclear Reactors, USA, Lulu, 2017.

2. Bolonkin A.A., Femtotechnologies and Innovative Projects, USA, Lulu, 2011, p.140.

3. Koshkin N.I., Shirkevich M.G., Spravochnik po jelementarnoj fizike [Handbook of elementary physics], Moscow, Nauka, 1982.

4. Kalashnikov C.G., Elektrichestvo [Electricity], Moscow, Nauka, 1985.

5. Wikipedia, Inertial Thermonuclear Reactor. 
DOI 10.32370/2018_11_3

\title{
Location of Industry
}

\author{
Dr. Umar Lawal Aliyu \\ Faculty of Management, Department of Business Administration \\ LIGS University Hawaii, USA \\ lawalacademy@gmail.com
}

\begin{abstract}
The term industry does not only refer to manufacture but all forms of goods and services produced. An industry is the production of goods or related services within an economy. In fact, it is an economic activity concerned with the processing of raw materials and manufacture of goods in factories and the services, which surround the use of these goods. The industry is the greatest sector that can provide employment to the mass people, which help to increase per capita, and reduces the poverty. The economic development of a nation depends on the stage of industrial development. Location of industry is the geographical spread of economic activity within an economy. However, multitude of factors influence the location decisions of firms and industries, including proximity to raw material supplies, availability of labour, good communications and nearness to markets. The placement and expansion of all Government all over the world irrespective of its economic and political policies are all Governments primary concerns. The research work will give definition, types of Industries and Factors of industrial Location. The thesis will tend to analyse location theories, advantage, and disadvantages of industrial location. It is good to note that whether used internally or exported produce from industrial activities generates revenue.
\end{abstract}

Keywords: Economy, Goods, Industry, Location, Manufacturing, Market, Production, Revenue, Services.

\subsection{INTRODUCTION}

Industry is the production of goods or related services within an economy. The major source of revenue of a group or company is the indicator of its relevant industry. The location of industry depends on which type of factory you are going to setup. For example, if you want to set an iron or steel company, you need to setup in place where there are rich iron ores and the waste can be released easily. A good example of this is Ajakuta Steel Rolling mill in Ajakuta in Nigeria by the Federal Government of Nigeria. It was located in Ajakuta in Nigeria were it is rich in Iron ore. Thus, if the industry is related to agriculture you need to setup near village area with fertile land for farming and rearing or breeding of animals. Another good example of this is the Mambila Agricultural production on the Mambilla fertile lands by the Federal Government of Nigeria with capacity area to 850 hectares and an out-grower scheme of 450 hectares. Another example is the Federal Executive Council on recent approval for the engineering work of the Mambilla Hydro Electric Power Plant in Taraba State at a sum of $\$ 5.792 \mathrm{bn}$. The project includes the construction of four dams, one of which would be 150 metres high; two others would be 70 metres high while the smallest dam will be 50 metres in height. 
The second aspect is cost of land; an industry is always tried to be installed in outer city area, as the people are less so it is easy to get pollution board approval and reasonable cost of land. Other factors to consider in the location include Natural routes, Transportation, Market, Labour etc.

\subsection{LITERATURE REVIEW}

\section{$2.1 \quad$ Theoretical Framework}

Industry is an economic activity concerned with the processing of raw materials and manufacture of goods in factories and the services, which surround the use of these goods. The term industry covers a multitude of meanings; in its narrowest sense, it may only refer to manufacturing- the making of goods but in its broadest sense, it refers to all stages and types of economic activity including extraction, construction and services.

Location of an industry is the idea and practice of establishing an industry by either government or an entrepreneur in a given area for economic, geographical, social or political reasons. Industrial location can also be defined strategic placement of various economic activities in relation to some specific factors. Perfect location of industry depends on factors like land, labour, capital, transportation, etc.

\section{$2.2 \quad$ Types of Industry}

$>$ Primary industry: Is any activity in which natural resources are acquire from the earth surface. Examples of primary industry include agriculture, fishing, dairy farming, forestry, mining, and quarrying.

$>$ Secondary industry: Deals with the manufacture of finished products by changing its shape or real nature and adding utility to it; resources collected at the primary level are changed into other products, thereby involving a certain amount of manufacturing. Examples of secondary industry include making sugar from sugarcane, converting of iron ore to steel etc.

$>$ Tertiary industry-Tertiary industry may be summarized as the distributive trades and as such, it includes the commercial services such as transport, wholesaling and retailing.

$>$ Service industry/Quaternary industry- quaternary industry comprises of all personal services. Unlike tertiary industry, it does not deal with goods but with people and requires generally higher levels of skill, expertise and specialization. Activities in such fields such as education, research, administration and financial management may be termed quaternary.

\subsection{Theories of Location of Industry}

When attempting to predict where a business should be located we should take into consideration three (3) assumptions; business owners want to maximise their advantages over 
competitors, they want to maximise their profit and they take into account variable cost such as energy supply, transport cost, labour cost etc. Thus, in doing so we shall come across theories Weber's least cost theory, Losch's Profit maximisation theory and Locational independence theory.

Weber's least cost theory: Alfred Weber formulated a theory of industrial location in which an industry is located where the transportation costs of raw materials and final product is a minimum. He singled out two special cases. In one, the weight of the final product is less than the weight of the raw material going into making the product. Weber's model seeks to design a least cost industrial location sighting three (3) basic economic factors; Transportation cost, Labour cost and Agglomeration economies.
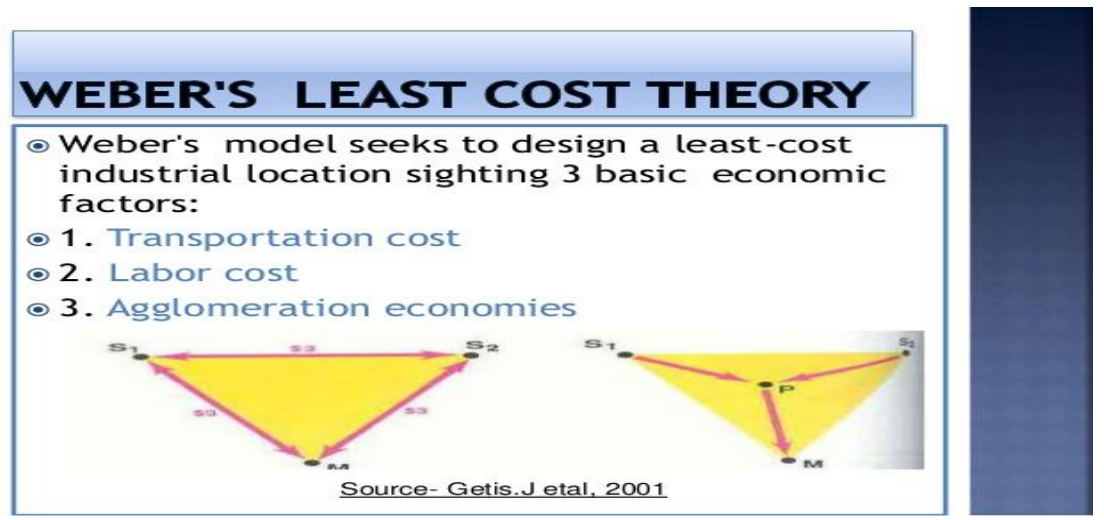

August Losch, a German economist, published his theory of 'Profit Maximisation' in the year 1954. The least cost location theory of Weber was wholly discarded by Losch. In fact, he suggested that, 'profit maximization' is the only objective of the entrepreneur, whether it is state or an individual. The theory states that the correct location of an industry lies where its profit is greatest.

\section{LOSCHOS PROFUT MAXHMESATHON THEORY}

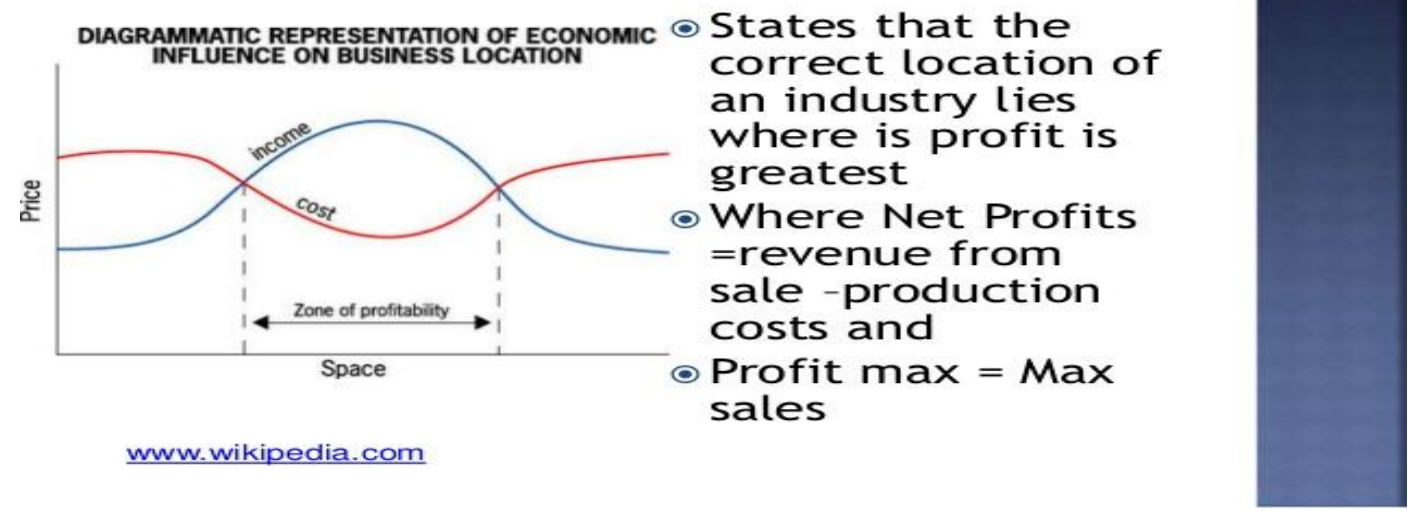

\subsection{Location of Industry Factors}


There are two types of approaches to industrial location; one is regional, attempts to assess the reasons why certain locations are attractive to industrialization generally and the second approach is industrial in perspective, and seeks to explain why an individual industry or firms are attracted to a particular location.

\section{FACTORS WHICH INFLUENCE iNDUSTRRAL LOCATION}

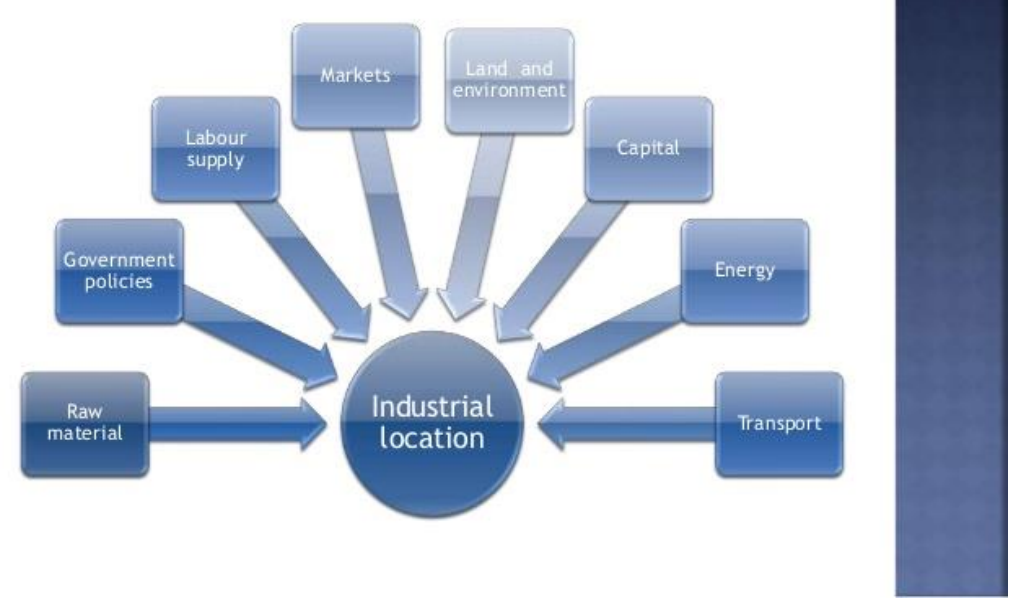

\section{Figure one - Location of Industry Factors}

The factors to be considered are many into the following below:

1) Human and Economic

$>$ Labour: A large cheap labour force is required for labour-intensive manufacturing industries but High-tech industries have to locate where suitable skilled workers are available. Estall and Buchanan showed in 1961 that labour costs can vary between $62 \%$ in clothing and related industries to $29 \%$ in the chemical industry; in the fabricated metal products industries they work out at $43 \%$.

$>$ Market: An accessible place to sell the products is essential for many industries: for bulky, perishable, fragile, size and prestige.

$>$ Transport: A good transport network helps reduce costs and make the movement of materials easier.

$>$ Cost of land: Sites in rural areas are usually cheaper than urban area.

$>$ Capital: Amount of money needed to start the business.

$>$ Government policies and politics: Industrial development is encouraged in some areas and restricted in others. This days Government intervene for various social, political and strategic reasons; For instance, USSR industries have been moved eastward into the Urals, Tashkent and Ukraine. 
Water: Many industries are established near rivers, canals and lakes. Iron and steel industry, textile industries and chemical industries require large quantities of water, for their proper functioning.

$>$ Climate: Areas with hash climate are not good for industries because people tend to work only where living conditions are favourable.

$>$ Others: Banking facilities, Efficient Organisation, Industrial agglomeration, Industrial Inertia and Insurance.

2) Physical

$>$ Raw materials: The factory needs to be close to raw material.

$>$ Energy supply: Regular supply of power is a pre-requisite for the localisation of industries. Coal, mineral oil and hydro-electricity are the three important conventional sources of power. Most of the industries tend to concentrate at the source of power.

$>$ Natural routes: River valleys and flat areas were essential in the days before railways and motorways made the movement of materials easier.

$>$ Site and land: Most industries require large accessible areas of cheap, flat land on which to build their factories.

\subsection{CONCLUSION}

Location of industry is the geographical spread of economic activity within an economy. A multitude of factors influence the location decisions of firms and industries like proximity to raw materials, water, labour, market, power etc. It should be noted that business owners want to maximise their advantages over competitors so in locating an industry they want to maximise their profit and they take into account variable cost such as energy supply, transport cost, labour cost etc.

\section{References}

1. Barcelona Field Sudies Center; Location of Industry Factors

2. Defoaming: Theory and Industrial Applications 1993

3. Economic theory of the industry Book by Michael Waterson 1984

4. Factors Influencing the Location of Industries: Geographical and Non Geographical Factors Article shared by Smriti Chand

5. Industrial Location Geo 2101 Carlesa Duncan 12/0613/0712

6. Industrial Organization: Markets and Strategies Textbook by Martin Peitz and Paul Belleflamme 2010

7. Industrial Organization: Theory and Applications Book by Oz Shy 1998

8. Industrial Organization: Theory and Practice Book by Don E. Waldman and Elizabeth J. Jensen 1998

9. Industry from Wikipedia, the Free Encyclopedia

10. Industry: Definition, Types of Industries and Factors of industrial Location by JotScroll

11. The Punch; FG Awards \$5.8bn Mambilla Power Plant Contract Published August 2017

12. The Theory of Industrial Organization Book by Jean Tirole 1988

13. Theory of the location of industries Book by Alfred Weber 1909 
DOI 10.32370/2018_11_4

\title{
Computer Crime
}

\author{
Dr. Umar Lawal Aliyu \\ Faculty of Management, Department of Business Administration \\ LIGS University Hawaii, USA \\ lawalacademy@gmail.com
}

\begin{abstract}
Crime is an action or omission, which constitutes an offence and is punishable by law. A crime is an offence that merits community condemnation and punishment, usually by way of fine or imprisonment. Crime takes place when a person deliberately practices deception in order to gain something unlawfully or unfairly. While crime is most commonly committed to obtain benefits of value, it sometimes occurs solely for deceiving another person or entity. Computer crime alternatively referred to as cybercrime, e-crime, electronic crime, or hi-tech crime is an act performed by a knowledgeable computer user, sometimes referred to as a hacker that illegally browses or steals a company's or individuals private information. In some cases, this person or group of individuals may be malicious and destroy or otherwise corrupt the computer or data files. Cybercrime may threaten a person or a nation's security and financial health. Issues surrounding these types of crimes have become high profile, particularly those surrounding hacking, copyright infringement, unwarranted mass-surveillance, extortion, child pornography, and child grooming. This paper focused on the causes, types, detection and prevention of computer crime. The paper also reviews the various forms and types of computer crime practice, their impact and recommendations that will curtail this bad menace.
\end{abstract}

Keywords: Crime, Computer crime, Data, Detection, Illegal, Offence, Prevention, Punishment

\subsection{INTRODUCTION}

The U.S. Department of Justice (DOJ), in its manual on computer crime, defines such crime as "any violations of criminal law that involve knowledge of computer technology for their perpetration, investigation, or prosecution." According to Professor Babatope Longe of Computer Security and Dean, Caleb Business School, Caleb University, Imota, Lagos State, cyber criminality and cyber victimization are crimes tied to the exploration of human frailties such as greed, gullibility and the untamed quest for getting rich syndrome and not crimes that are necessarily influenced by social factors such as poverty, inequality and unemployment.

Cybercrime, or computer-oriented crime, is the crime that involves a computer and a network. The computer may have been used in the commission of a crime, or it may be the target. Cybercrimes can be defined as: "Offences that are committed against individuals or groups of individuals with a criminal motive to intentionally harm the reputation of the victim or cause physical or mental harm, or loss, to the victim directly or indirectly, using modern telecommunication networks such as Internet (networks including but not limited to Chat rooms, emails, notice boards and groups) and mobile phones (Bluetooth/SMS/MMS)". Vices such as hacking, phishing, cyber stalking, online pornography, advance fee fraud and cyber 
terrorism are examples of those cybercrimes and are traceable all over the world. Cybercrime includes any type of illegal scheme that uses one or more components of the Internet (chat rooms, email, message boards, websites, and auctions) to conduct fraudulent transactions or transmit the proceeds of fraud to financial institutions or to others connected with the scheme. Cybercrime also applies to generating spam emails, downloading viruses or spyware to computer, harassing another through the Internet, child pornography, and solicitation of prostitution online. Perhaps the most prominent form of cybercrime is identity theft, in which criminals use the Internet to steal personal information from other users.

The thrust of the research thesis is to examine computer crime, types of computer crime and give recommendations in order to reduce the pitfall individuals, banks went through in the hands of cybercriminals in recent years.

\subsection{LITERATURE REVIEW}

\subsection{Theoretical Framework}

Throughout the past, several decades there have been numerous advances in electronic resources. Technologies such as cellular phones, pagers, home computers, the Internet, websites, and palm pilots have added another dimension to crime. While each of the networks that make up the Internet is owned by a public or private organization, no single organization or government owns or controls the Internet. Originally created to further defence, scientific and academic endeavours, the Internet which also affords users the ability to communicate via electronic mail ("e-mail"), grew slowly but steadily until 1994. At that time, the World Wide Web ("the Web"), the graphical user interface to the Internet, was introduced which prompted extraordinary growth in both the size and the use of the Internet.

Internet and the Web importance rocketed in the economy and globally with Ecommerce, Online businesses, credit card purchases over the Internet 24-hours-a-day and host of plenty goodies but also faced with cybercrime; generating spam emails, downloading viruses or

spyware to computer, harassing another through the Internet, child pornography, and solicitation of prostitution online. Cyber criminals use internet and computer technology to hack user's personal computers, smartphone data, and personal details from social media, business secrets, national secrets etc. Criminals who perform these illegal activities through the internet are called - Hackers. Though law enforcement agencies are trying to tackle this problem, it is growing regularly and many people have become victims of identity theft, hacking and malicious software.

\subsection{Causes of Computer Crime}

We are living in the modern era based on the technology. Our daily life depends on it, live with it. Therefore, nowadays the internet is a common name known to everyone. Millions of people globally on daily basis use computers and the internet. They are used in houses, 
schools, work and in fact have become part of our life and daily activities. Computers have made our life easier, it has brought so many benefits to the society but it has also brought some problems and cybercrimes is one of them. The Internet contains everything we need. Thus, people are using, depending on it more, and more.

However, causes of cybercrime can be attributed to the following below:

a. Negligence: Negligence provides a cyber-criminal the access and control over the computer system.

b. Greed: 'Greed' is one of the main causes for people falling prey to cybercrimes despite extensive exposure of its dangers by authorities and cautionary tales from cheated victims.

c. Loss of evidence: This has become a very common and obvious problem, which paralyzes the system behind the investigation of cyber-crime.

d. Complex: The computers run on operating systems and these operating systems are programmed of millions of codes. The human mind is imperfect, so they can do mistakes at any stage. The cyber criminals take advantage of these gaps.

e. Easy to access: Hackers can steal access codes, retina images, advanced voice recorders etc. that can fool biometric systems easily and bypass firewalls can be utilized to get past many security systems.

f. Capacity to store data in comparatively small space: This makes it a lot easier for the people to steal data from any other storage and use it for own profit.

\subsection{Types of Cyber Crime}

a. Child pornography and Abuse: Making or distributing child pornography.

b. Hacking: Refers to unauthorized intrusion into a computer or a network. Hacker accesses personal or sensitive information without authorisation.

c. Piracy or Theft: This crime occurs when a person violates copyrights and downloads music, movies, games, and software. Copyright violation is stealing or using another person's Copyrighted material without permission.

d. Cracking: Breaking or deciphering codes that are being used to protect data.

e. Cyber terrorism: Hacking, threats, blackmailing towards a business or person.

f. Cyber bully and Cyber stalking: This is a kind of online harassment wherein the victim is subjected to a barrage of online messages and emails.

g. Identity theft: Pretending to be someone you are not.

h. Cybersquatting: Setting up a domain of another person or company with the sole intentions of selling it to them later at a premium price.

i. Creating Malware: Writing, creating, or distributing malware (e.g., viruses and spyware.)

j. Denial of Service attack: Overloading a system with so many requests it cannot serve normal requests.

k. Espionage: Spying on a person or business. 
1. Fraud - Manipulating data, e.g., changing banking records to transfer money to an account or participating in credit card fraud.

m. Harvesting: Collect account or other account related information on other people.

n. Human trafficking: Participating in the illegal act of buying or selling other humans.

o. Identity theft: Pretending to be someone you are not.

p. Illegal sales: Buying or selling illicit goods online including drugs, guns, and psychotropic substances.

q. Intellectual property theft: Stealing practical or conceptual information developed by another person or company.

r. IPR violation: An intellectual property rights violation is any infringement of another's Copyright, patent, or trademark.

s. Phishing: Deceiving individuals to gain private or personal information about that person.

t. Salami slicing: Stealing tiny amounts of money from each transaction.

u. Scam: Tricking people into believing something that is not true.

v. Slander: Posting libel or slander against another person or company.

w. Software piracy: Copying, distributing, or using software that is Copyrighted that you did not purchase.

x. Spamming: Distributed unsolicited e-mail to dozens or hundreds of different addresses.

y. Spoofing: Deceiving a system into thinking you are someone you really are not.

z. Typosquatting - Setting up a domain that is a misspelling of another domain.

aa. Unauthorized access - Gaining access to systems you have no permission to access.

bb. Wiretapping - Connecting a device to a phone line to listen to conversations.

\subsection{CONCLUSION}

Even though, computers are introduced with the view of making things easier for those who use them, it has become an avenue for the easiest fraud to take place in the whole world. It has one Logo: "Garbage in - Garbage Out. To tackle cybercrime effectively, establish multidimensional public-private collaborations between law enforcement agencies, the information technology industry, information security organizations, internet companies and financial institutions.

Also, use Strong Passwords, Be social media savvy, Secure your Mobile Devices, Protect your data, Protect your identity online, Keep your computer current with the latest patches and updates, Protect your computer with security software and always call the right person for help.

\section{References}

1. Causes of CyberCrime and Preventive Measures by Ravi Bandakkanavar | August 30, 2017

2. Causes of CyberCrime and Preventive Measures by Ravi Bandakkanavar 2017

3. Coding Freedom: The Ethics and Aesthetics of Hacking by E. Gabriella Coleman 2012 
4. Computer Hope Free Computer Help by Computer Hope since 2018

5. Cybercrime From Wikipedia, the free encyclopaedia

6. FTC Targets Computer Support Scams by Information Management, Vol. 47, No. 1, 2013

7. Greed, Cause of Cybercrime by Dayo Adesulu June 2015

8. Legal Services Commission of South Australia; Criminal and Traffic Offences - Revised 2017

9. New Global Cybercrime Calls for High Tech Cyber-Cops by McMahon, Richard; Bressler, Martin S.; Bressler, Linda 2016

10. Phishing, Pharming and Identity Theft by Brody, Richard G.; Mulig, Elizabeth; Kimball, Valerie 2009

11. Risk Factors in Computer-Crime Victimization by Kyung-Shick Choi 2010

12. USLegal; Cybercrimes Law and Legal Definition 


\title{
The Cook-Levine Hypothesis
}

\author{
Equality of Classes, $\mathbf{P}=\mathbf{P N}$ \\ (Easily Solvable Problems Are Easily Checked) \\ Mustafaev Rustem Eyvasovich, \\ Klyueva Elena Sergeevna, \\ Boytsun Galina Viktorovna
}

\begin{abstract}
The goal of the paper is to show the equality $\mathrm{P}=\mathrm{PN}$ on mathematical, physical, chemical, biological, social examples and laws.

The goal is to explain the mechanism of equality of classes $\mathrm{P}=\mathrm{PN}$.

Keywords: square of conditions; dominant trait; 7 ; equality PN; interrelated tasks; neutrality
\end{abstract}

Равенство классов NP=P.

Примем Р за ответ, NP - решение задачи, где $\mathrm{N}$ - её условия; Тогда класс NP есть комплекс условий, обосновывающих решение, и ответа Р. Ответ, взаимодействуя с условиями $\mathrm{N}$, решает обратную задачу, т.е. проверку решения. Это схематически выражается так: $\mathrm{NP=P}$. Стрелки означают применимость $\mathrm{N}$-условий как к решению задачи, так и её проверке. Проверка сводится к подтверждению правильности значений, указанных в условии, при использовании ответа; также необходимо проверить возможность решения задачи на базе теоретической обоснованности, отсутствии противоречий с установленными законами, закономерностями, аксиомами, доказательствами, т.е. научной основой, которую обозначим (две стрелки в виде буквы «V»). Значит, условия задач должны подчиняться (принадлежать) научной основе, что позволяет решить задачу и проверить её решение.

$\mathrm{N} \in \longrightarrow \mathrm{PN}=\mathrm{P}$ - условие возможности решений. Если параметр $\mathrm{N}$ (условия) применим к решению задачи и её проверке, используем простое математическое тождество, умножив две части равенства на $\mathrm{N}$, получим: $\mathrm{PN}^{2}=\mathrm{PN}$; Для ясности $\mathrm{P}$ обозначим при решении задачи как $\mathrm{P}_{1}$; при её проверке как $\mathrm{P}_{2}$. 
Тогда:

$\mathrm{P}_{1} \mathrm{~N}^{2}=\mathrm{P}_{2} \mathrm{~N} ; \mathrm{B}$ произведении $\mathrm{P}_{2} \mathrm{~N},-\mathrm{P}_{2}$ (полученный ответ); $\mathrm{N}-$ (условия задачи, данные которой, (числовые и иные параметры), - проверяются с помощью полученного ответа).

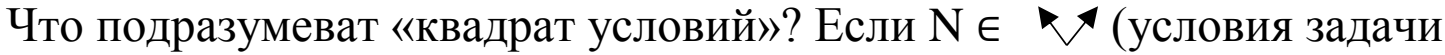
принадлежат законам, на основе которых она решается), то созданные, взаимодействующие условия $\mathrm{N}^{2} \in{ }^{2}$, т.е. отвечают количеству законов и аксиом, доказательств, превосходящему теоретическую базу для решения первоначальной задачи в квадрате, что позволяет решить и проверить дополнительные смежные задачи. Так как $\mathrm{N}^{2}$ - положительные значения, вектор $\overrightarrow{\mathrm{N}_{2}}$ и $\overrightarrow{\mathrm{N}}$ имеют одно направление и совпадают.

Рис. 1

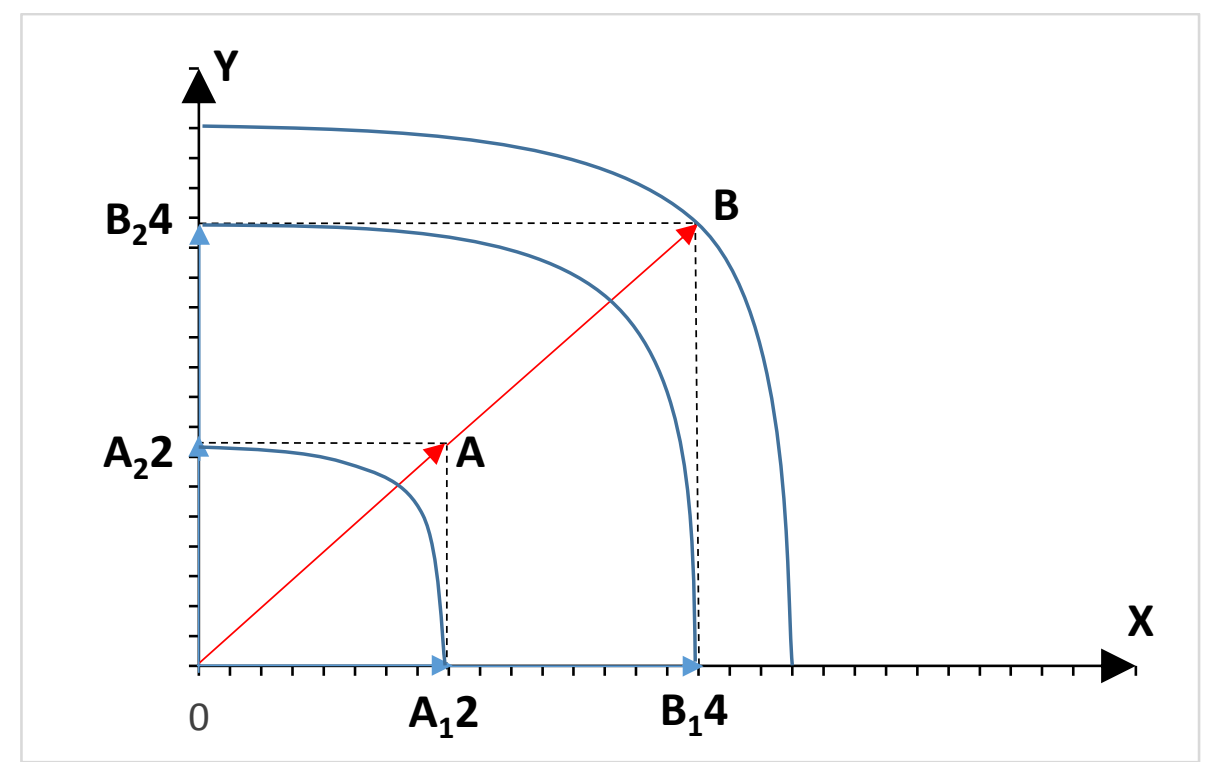

Радиус $|0 \mathrm{~A}|$ соответствует N; радиус $|0 \mathrm{~B}|-\mathrm{N}^{2} ;|0 \mathrm{~A}|=2,|0 \mathrm{~B}|=2^{2}=4$.

Если считать, что условия задачи просты и не сложна их теоретическая основа, то они (и $\mathrm{N}^{2}$ ) соответствуют осям $0 \mathrm{X}$ и $0 \mathrm{Y}$, а радиусы окружностей $\left|0 \mathrm{~A}_{1}\right| ;\left|0 \mathrm{~A}_{2}\right|$ (отвечают $\mathrm{N}$ ), и $\left|0 \mathrm{~B}_{1}\right| ;\left|0 \mathrm{~B}_{2}\right|,\left(\mathrm{N}^{2}\right)$, - будут невелики.

Если условия задачи сложнее, и сложнее их теоретическая основа, - векторы $\overrightarrow{\mathrm{N}}$ и $\overrightarrow{\mathrm{N}^{2}}$ будут расположены под углом к осям $0 \mathrm{X}$ и $0 \mathrm{Y}$, и радиусы окружностей $|0 \mathrm{~A}|-(\mathrm{N}) ;|0 \mathrm{~B}|,\left(\mathrm{N}^{2}\right)$ будут больше. Взаимосвязанные задачи и их условия образуют концентрические окружности в системе координат $\mathrm{X} 0 \mathrm{Y}$.

Условия относительно узкой задачи можно обозначить как $\mathrm{N}_{1}$; более широкой, развернутой задачи, смежной или аналогичной первой, как $\mathrm{N}_{2}$; 
объемной задачи, построенной на широкой теоретической базе, $-\mathrm{N} .$. Взаимосвязанные задачи имеют связанные логически условия, т.е.:

$\mathrm{N}_{1}<\mathrm{N}_{2}<\mathrm{N} ; \mathrm{N}_{1} \in \mathrm{N}_{2} \in \mathrm{N}$. Соответственно $\mathrm{P}_{1} \mathrm{~N}_{1}<\mathrm{P}_{2} \mathrm{~N}_{2}<\mathrm{PN}$. Для смежных взаимодополняющих задач $\mathrm{P}_{1} \mathrm{~N}_{1} \rightleftarrows \mathrm{P}_{2} \mathrm{~N}_{2} \rightleftarrows \mathrm{PN}$. (Решение меньшей задачи дает возможность решить большую задачу, решение широкой, развернутой задачи решает меньшие задачи). Совокупность решений меньших задач чаще равнозначна решению крупной задачи. Выражается это так: $\mathrm{P}_{1} \mathrm{~N}_{1}+\mathrm{P}_{2} \mathrm{~N}_{2}=$ $\mathrm{PN}$. Взаимосвязь условий $\mathrm{N}_{1}$ и $\mathrm{N}_{2}$ позволяет их объединить в одно развёрнутое условие, т.е. в сумму: $\left(\mathrm{N}_{1}+\mathrm{N}_{2}\right)$. Объединение условий позволяет сгруппировать и ответы: $\left(\mathrm{P}_{1}+\mathrm{P}_{2}\right)$. Тогда $\mathrm{P}_{1} \mathrm{~N}_{1}+\mathrm{P}_{2} \mathrm{~N}_{2}=\left(\mathrm{P}_{1}+\mathrm{P}_{2}\right)\left(\mathrm{N}_{1}+\mathrm{N}_{2}\right)$ или $\mathrm{PN}=$ $\left(\mathrm{P}_{1}+\mathrm{P}_{2}\right)\left(\mathrm{N}_{1}+\mathrm{N}_{2}\right)$. Если $\mathrm{N}_{1} \in \mathrm{N}_{2}$, т.е. из условия $\mathrm{N}_{2}$ вытекает условие $\mathrm{N}_{1}$, то сумма $\left(\mathrm{N}_{1}+\mathrm{N}_{2}\right)$ по смысловому значению равна $\mathrm{N}_{2} ;\left(\mathrm{N}_{1}+\mathrm{N}_{2}\right)=\mathrm{N}_{2}$, или $\mathrm{PN}=$ $\left(\mathrm{P}_{1}+\mathrm{P}_{2}\right) \mathrm{N}_{2}$; применим условие $\mathrm{N}_{2}$ как соответствие к условию $\mathrm{N}: \mathrm{P}=\frac{\left(P_{1}+P_{2}\right) N_{2}}{N}$ ; Отношение $\frac{N_{2}}{N}$ (условие более узкой задачи к условию более развёрнутой задачи) позволяет установить их совместимость и взаимосвязь на основе законов, закономерностей, аксиом и доказательств.

То есть: $\frac{N_{2}}{N} \rightarrow$

$\checkmark$ - логическая категория суждения, «теоретическая база».

Тогда следует: $\mathrm{P}=\left(\mathrm{P}_{1}+\mathrm{P}_{2}\right)$ З Знаем, что $\mathrm{N} \in$, и значения $\mathrm{P}_{1} ; \mathrm{P}_{2}$ (ответы решений и альтернативных решений) применимы к $\mathrm{N}$ (условиям задачи).

Тогда: $\mathrm{P}=\left(\mathrm{P}_{1}+\mathrm{P}_{2}\right) \mathrm{N} \longleftarrow$ Известно, что группа ответов $\left(\mathrm{P}_{1}+\mathrm{P}_{2}\right)$ может быть получена при решении $\mathrm{PN}$ наиболее общей (развёрнутой) задачи, т.е. $\left(\mathrm{P}_{1}+\mathrm{P}_{2}\right)=\mathrm{P}$. Тогда из равенства $\mathrm{P}=\left(\mathrm{P}_{1}+\mathrm{P}_{2}\right) \mathrm{N} \longrightarrow \mathrm{PN}$, или $\mathrm{P}=\mathrm{PN}$ (доказательство гипотезы Кука-Левина).

Для проверки решения задачи к полученному ответу необходимо применить условия, согласно равенсту $\mathrm{PN}^{2}=\mathrm{PN}$.

Вывод: применение теоретичсекой доказанной базы в решении задачи $\left(\mathrm{N}^{2}\right)$, ведет к применению условия $(\mathrm{N})$ к полученному ответу $(\mathrm{P})$ для проверки её решения, и наоборот, чем объясняется равенство классов, $\mathrm{P}=\mathrm{PN}$ (гипотеза Кука-Левина, решение).

Рассмотрим взаимодействие $\mathrm{P}$ (ответов) и $\mathrm{N}$ (условий) в системе координат $\mathrm{X} 0 \mathrm{Y}$.

Количеству условий задач равно количество ответов (или групп ответов), т.е.

$$
\{\mathrm{P}=\{\mathrm{N} \text {. }
$$


Рис. 2

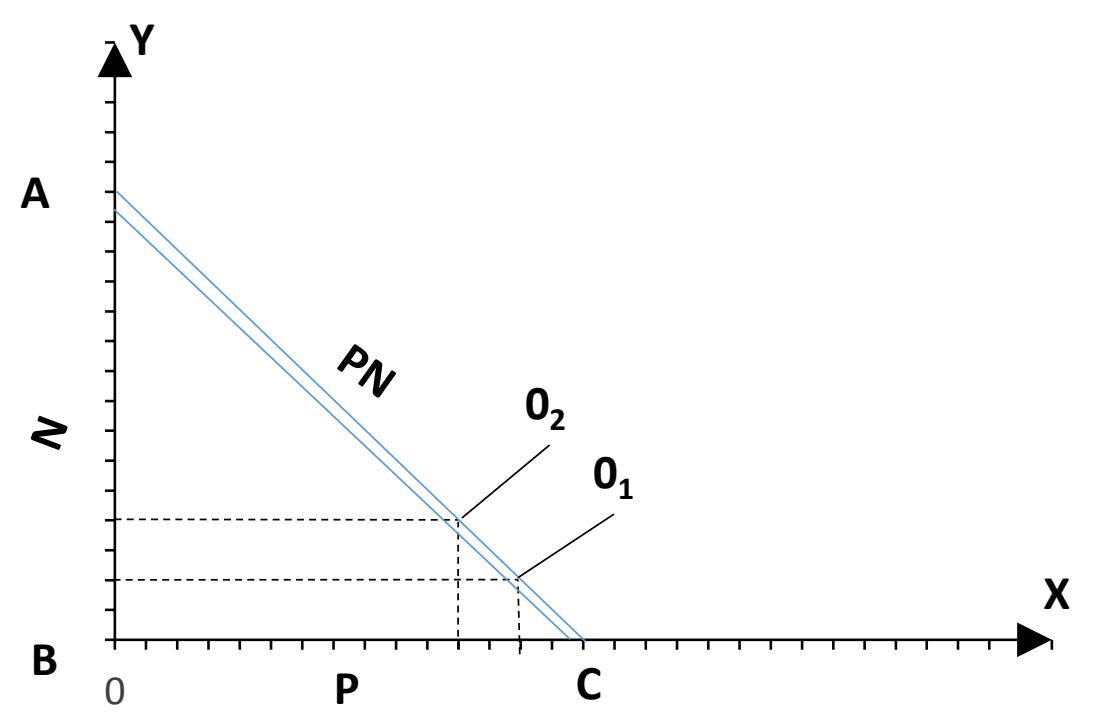

$\Delta \mathrm{ABC}$ - равнобедренный; $|\mathrm{AB}|=\mathrm{N}=|\mathrm{BC}|=\mathrm{P} .|\mathrm{AC}|=\mathrm{PN}$.

Взаимодействие $\mathrm{P}$ и $\mathrm{N},-$ проекции точек на гипотенузу $|\mathrm{AC}|$, в виде точек $0_{1} ; 0_{2}$.

Видна зависимость, - чем меньше (уже) условия $(\mathrm{N})$, тем больше (P), легче решение и получение ответа. $\triangle \mathrm{ABC}-$ прямоугольный, $\widehat{\mathrm{ABC}}=90^{\circ} ; \mathrm{BAC}=$ $45^{\circ} ; \widehat{\mathrm{ACB}}=45^{\circ} ;$ Угол взаимодействия векторов Р и $\mathrm{N}$ прямой,$\left(90^{\circ}\right)$, соответствует плоскостям трёхмерного пространства (в котором производится большинство исчислений и доказательств).

Согласно правилам прямоугольного треугольника получаем:

$(\mathrm{PN})^{2}=\mathrm{P}^{2}+\mathrm{N}^{2} ;$ Если $\mathrm{N}^{2}=4^{2}$, то $(\mathrm{PN})^{2}=\mathrm{P}^{2} \rightarrow \underline{\mathrm{PN}=\mathrm{P}}$.

Равенство классов подтверждается и физическими законами... Рассмотрим закон сохранения энергии...

$E k_{1}+E p_{1}=E k_{2}+E p_{2}$

$E k_{1}+E p_{1}-E k_{2}=E p_{2}$

$\frac{m V_{\min }^{2}}{2}+m g h_{\max }-\frac{m V_{\max }^{2}}{2}=m g h_{\min }$

$\frac{m V_{\min }^{2}}{2} \rightarrow 0 ; m g h_{\min } \rightarrow 0$, тогда $m g h_{\max }=\frac{m V_{\max }^{2}}{2} ; E p_{1}=E k_{2}$

Примем условно $E p_{1}=P N=m g h_{\max }, m g h=m g V t,(\mathrm{~h}=\mathrm{Vt}-$ расстояние, высота ).

$\mathrm{V}=$ at ( скорость равна произведению ускорения на время). 
Тогда $m g h=m g V t=m g *$ at $* \mathrm{t}$;

Если при свободном падении $\mathrm{a}=\mathrm{g}=9,8 \mathrm{~m} / \mathrm{c}^{2}$, то

$E p_{1}=m g * g t^{2}=m g^{2} t^{2}=m(g t)^{2}=m V^{2}$, так как gt $=\mathrm{V}$.

Примем $\mathrm{Ek}_{2}=\mathrm{P}$. “Если Ер $\mathrm{p}_{1}$ можно преобразовать в $m V^{2}$, а $E k_{2}=\frac{m V_{\max }^{2}}{2}$, то $P N=m V^{2}=E p_{1}=E k_{2}=\frac{m V^{2}}{2}=P$; То есть подтверждается равенство классов $\mathrm{P}$ и $\mathrm{PN}$, так как следует, что

$2 m V^{2}=m V^{2} ; \rightarrow N=2 ; 2 P=P \rightarrow P N=P$."

Решение задачи можно преобразовать в проверку, проверку в решение, свойство обратимости классов PN; P.

Обратимость многих химических реакций, сохранение массы образуемых веществ подтверждает равенство классов.

Рассмотрим реакцию водорода с йодом." $H_{2}+J_{2} \rightleftarrows 2 H J$. При определенном температурном режиме, от $170^{\circ}$ до $200^{\circ} \mathrm{C}$ (Не ровный нагрев) - реакция будет идти в двух направлениях, - с образованием кислоты и её разложением. При этом молекулярная масса йода и водорода всегда будет равна массе образуемой кислоты при равенстве скоростей прямой и обратной реакций, такое состояние называется химическим равновесием.

$$
\begin{aligned}
& M\left(H_{2}\right)=2 * 1=2 \text { ед. } \\
& M\left(J_{2}\right)=2 * 127=254 \text { ед. } \zeta 256 \text { ед. } \\
& M(2 H J)=2 *(1+127)=256 \text { ед. }
\end{aligned}
$$

Расчет подтверждает сохранение массы вещества.

Закону сохранения материи, вещества подчиняются все химические ( в том числе необратимые), и биологические процессы.” Вещество никуда не исчезает, оно лишь переходит из одного состояния в другое, по аналогии с сохранением энергии. Равенство классов подтверждает и генетика, как раздел биологии.

23 мужских и 23 женских хромосомы, ( $\mathrm{Y}$ и $\mathrm{X}$ - хромосомы дают начало мужскому полу, происходит доминирование $\mathrm{Y}$ - хромосом )

$X * Y \rightarrow Y$ (Мужской пол).

При встрече женских $\mathrm{X}$ - хромосом пол ребёнка - женский $X * X \rightarrow X$.

Вывод: произведение PN можно рассматривать как влияние ответа Р на условия задачи $\mathrm{N}$, или “ условия задачи влияют на её ответ так, что получается ( доминирует ) ответ Р. 
Также логична формулировка, - признак Р ( задачи, явления, процесса ) влияет на признак $\mathrm{N}$ так, что получается признак $\mathrm{P}$ ( доминантный признак ). Признак $\mathrm{N}$ - рецессивный ( слабый, подавляемый ). Равенство $\mathrm{PN}=\mathrm{P}$ следует считать доминирующим тождеством.

Например, смешение признаков негритянской расы с признаками европейской, - в фенотипе проявит признаки черной расы... Простейшие математические примеры:

- умножение любого числа на “1” даёт это число - умножение положительного числа на отрицательное даёт отрицательный результат

- как не меняются условия касания к окружности прямой, точкой касания в количественном смысле останется одна точка. $\mathrm{P}$ - признак количества точек; $\mathrm{N}$ - условия расположения прямой.

- расположение прямой в пространстве не влияет на её длину. $\mathrm{P}$ - длина прямой. $\mathrm{N}$ - пространство.

Хорошим подтверждением равенства классов есть невесомость.

Вес равен: $\mathrm{P}=\mathrm{gm}$ ( для свободно падающих тел ). Вблизи поверхности земли $\mathrm{g}=9,8 \mathrm{~m} / \mathrm{c}^{2}$. В космосе $g \rightarrow 0$, соответственно $P \rightarrow 0$. Если $g=0$, тогда $g m=0$. Заменим $g$ на $\mathrm{P}, \mathrm{m}$ на $\mathrm{N}$, получим $\mathrm{P}=\mathrm{PN}$.

Вывод: равенство P = PN соблюдается всегда, если Р ( ответ, признак ) основан на теоретической доказаной базе. $\mathrm{P} \rightleftarrows$.

$\mathrm{N}$ - условия; среда взаимодействия; вероятность.

Если считать $\mathrm{N}$ - вероятностью, то при любых задачах обязательно вероятен хотя бы один ответ, т.е если $\mathrm{N}=1$, то $\mathrm{P}=\mathrm{PN}$. Это аксиомное утверждение

“ Парадоксально применение этого равенства к общественно-политическим процессам.” Рассмотрим следующее. Пусть Р - “революционная ситуация” с известными признаками - “Верхи не могут... низы не хотят.” $\mathrm{N}$ - условия, среда её развития ( территория, состав населения, религиозность и т.д. ) ...

Допустим, ситуация получила развитие и произошла революция, как обычно принято считать. Тогда смысл “P” слева и справа в равенстве $\mathrm{P}=\mathrm{PN}$ разный.

Но если рассмотреть многие страны, к примеру, Ливию, то станет ясно, что тождество со времени Ливийской революции до свержения Каддаффи сохранялось, а именно, - первый этап революционной ситуации, когда Ливия обрела независимость, - через длительный интервал времени перешёл во второй - противостояние оппозиции и свержение Каддафи... При этом алгоритм революционной ситуации не исчез, а находится в “стадии ремиссии, ожидания." Тогда понятно, что условие $\mathrm{PN}=\mathrm{P}$ выполняется. 
Не зря диалектический материализм утверждает, - события в истории развиваются по спирали, повторяются. "Но продолжим рассмотрение вопроса с позиции вычислительных наук.”

Известно, из теории относительности Эйнштейна, что $\mathrm{E}=\mathrm{mc}^{2}$. Для элементарных частиц $m \rightarrow 0$ ( для отдельнно взятой частицы - протона, электрона, фотона, - масса ничтожно мала ). Тогда энергия отдельно взятой частицы также ничтожно мала, $E \rightarrow 0$. “ Лишь поток огромного количества частиц, $\mathrm{n}$ - количество, может обладать существенной энергией, $E=n * m c^{2}$ ( C - скорость света, 300000 м/c ). n - количество элементарных частиц; $\mathrm{m}$ масса частицы. " Энергия потока частицы может быть применена в различный интервал времени.

Контролируемую ядерную реакцию используют в реакторах на АЭС (и т.д.), не контролируемую при взрыве. Условно это выразим так $E=n m c^{2} * t$ ( измеряется в Дж * сек ). Если энергия используется моментально ( взрыв ), то есть, в 1 сек ( условную секунду), то $E=n m c^{2}$; тогда получим:

$n m c^{2} * t=n m c^{2}$. Если принять $n m c^{2}$ как $\mathrm{P}$, а время за $\mathrm{N},-$ получаем:

$\mathrm{PN}=\mathrm{P} \ldots$ В решении применён доминирующий параметр - время применения энергии. Равенство подтверждается взаимодействием заряженных частиц с нейтронами. Последние не влияют на количество и заряд, скажем, протонов.

Простейшим подтверждением равенства $\mathrm{P}=\mathrm{PN},-$ есть нейтральность атома, при положительном заряде ядра и отрицательном электронов на своих энергетических уровнях. Рассмотрим атом водорода.

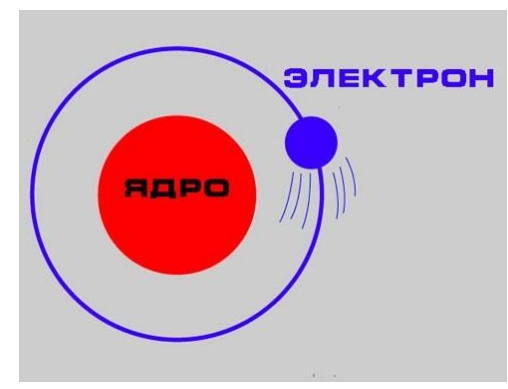

Орбиталь единственного электрона атома водорода имеет сферическую, (шарообразную форму). Движение электрона по сферической S-орбитали, оборот на $360^{\circ}$ вокруг ядра. Это взаимодействие выражается так:

$\left|p^{+}\right|=\sin 360^{\circ}\left|e^{-}\right|$.

$\left|p^{+}\right|(H)=\left|e^{-}\right|(H)$. Заменим $\left|e^{-}\right|$на $\left|p^{+}\right|$, если абсолютные значения равны.

$\sin 360^{\circ}=N=1$. Тогда: $\left|p^{+}\right|=\sin 360^{\circ}\left|p^{+}\right|$, или $\mathrm{P}=\mathrm{NP}$. 
Таким образом, равенство $\mathrm{P}$ = NP выполняется, если для ответа $\mathrm{P}$ существует условие $\mathrm{N}$ на основе теоретической доказанной базы. $\mathrm{N} \in \rightarrow \rightarrow \mathrm{P}=\mathrm{PN}$.

Поэтому условия задач включают вероятность решений, что позволяет решить прямую и обратную задачу, - проверить её. Задачи можно разделить на очевидные ( легко решаемые ), и неочевидные ( парадоксальные), решение и проверка которых проблемна.

\section{Дополнение}

Равенство P=PN - фактически обратимое отображение, биекция между двумя классами, множествами, задачами.

$\mathrm{P}+\mathrm{PN}=\mathrm{P}(1+\mathrm{P})$. Если $\mathrm{P}-$ проверка решения задачи, $\mathrm{N}-$ заданные условия задачи, то для решения задачи и ее проверки расширенное условие $(1+\mathrm{N})$, превышающее более частное (узкое) условие на один частный вариант. Если значение $(1+\mathrm{N})$ интерпретировать с геометрическим параметром, то $1=\sin 360^{\circ}$ (угол $360^{\circ}$ образует окружность). Тогда $\mathrm{P}+\mathrm{PN}=\mathrm{P}\left(\sin 360^{\circ}+\mathrm{N}\right)$. Выражаясь математическим языком, сумма классов P и PN образует «кольцо» - алгебраическая структура, в которой предусмотрена обратимость операций. $\sin 360^{\circ}+\mathrm{N}=\frac{P+P N}{P}$, или

$\frac{\sin 360^{\circ}+\mathrm{N}}{P}=\frac{P+P N}{P^{2}}, \rightarrow\left(\sin 360^{\circ}+\mathrm{N}\right) \mathrm{P}^{2}=\mathrm{P}(\mathrm{P}+\mathrm{PN})$

Данное равенство означает, что ответ «Р» применим к единой проверке задачи и ее решению, дает возможность проверить правильность решения в кольцеобразном замкнутом цикле с учетом условия поставленной задачи, получив точность решения, равную квадратной степени ответа при узком решении задачи.

ВЫВОД: Возможность совместного, общего действия по решению задачи и ее проверке, согласно равенсту $\mathrm{P}(\mathrm{P}+\mathrm{PN})=\left(\sin 360^{\circ}+\mathrm{N}\right) \mathrm{P}$ подтверждает равнозначность классов $\mathrm{P}$; PN в алгебраической структуре - кольце, их равенство.

\section{References}

1. Myakshev G.Ya., Bukhovtsev B. B., Charugin V. M. Fizika [Physics], 2010. 


\title{
Гипотеза Кука-Левина \\ Равенство классов, P=PN (легкорешаемые задачи легко проверяются) \\ Мустафаев Рустем Эйвасович, Клюева Елена Сергеевна, Бойцун Галина Викторовна
}

\begin{abstract}
Аннотация
В работе поставлена задача показать равенство P=PN на математических, физических, химических, биологических, социальных примерах и законах.

Цель - объяснить механизм равенства классов $\mathrm{P}=\mathrm{PN}$.

Ключевые слова: квадрат условий; доминантный признак; взаимосвязанные задачи; нейтральность.
\end{abstract}

\section{Использованная литература}

1. Мякишев Г.Я., Буховцев Б.Б., Чаругин В.М. Физика, 2010. 
DOI 10.32370/2018_11_13

\title{
Specific Features of Professionally Oriented Written Communication in English of IT Specialists
}

\author{
Shandra Natalia \\ ORCID: https://orcid.org/0000-0003-1321-4828 \\ Assistant Professor \\ Ivan Franko National University of Lviv (Ukraine)
}

\begin{abstract}
The article reveals the peculiarities of professionally oriented written communication in English of IT specialists. In the framework of the main situations of professionally oriented written communication in English (business correspondence, correspondence with colleagues and chiefs) the functions of the communication realize: contact, information, inducing, cognitive, emotive, influencing and fence-mending ones. The genres of professionally oriented written communication in English of IT specialists include: private and business e-mail correspondence, texting in chats and forums, posting on electric announcement boards, memo, and reports. The main types of this communication are informal (communication with colleagues), semi-formal and formal (communication with suppliers, clients, chiefs), analytical and scientific communication (reports). Each type of communication has its peculiar stylistic feature concerning lexical and grammatical presentation.

Key words: professionally oriented written communication in English, IT specialists, functions and duties, correspondence, genres, types of communications.
\end{abstract}

\section{Introduction}

An efficient operation of IT company can be achieved by available highly qualified specialists which display both a high level of professional competence and ability to produce written and oral professionally oriented communication by means of language of global communication - English.

The purpose of the article is to reveal the peculiarities of professionally oriented written communication in English of IT specialists.

According to the purpose, the objectives of the article are as follows:

1) to outline the list of specialties which higher educational institutions in Ukraine follow to provide training of prospective IT specialists, and also the range of professional functions and duties of IT specialists;

2) to analyze the essence of key concepts: "communication", "written communication", "written English professionally oriented communication of IT specialists"; 
3) to ascertain situations, functions, genres, types, features of professionally oriented written communication in English of IT specialists.

Nowadays F. Batsevych, O. Selivanova are researching the issues of communicative linguistics and intercultural communication. The study of professionally oriented communication of non-philological specialties has received a wide attention in the research of S. Kozhushko, N. Mykytenko, M. Kozolup, V. Sulym, O. Tarnapolskyi and others. M. Castelss, O. Dedova, D. Moursund, Shunhui Zhao, V. Romashenko, F. Smirnov investigated the peculiarities of communication by the means of information and communication technologies.

\section{Professional functions and duties of IT specialists}

Job placement of specialists in IT technologies isn't confined only to IT companies, they can work at any enterprises or organizations that use modern ICT technologies and process huge amount of information. Nowadays there are computers and computer networks in any offices and employees use relevant software. Regardless of place of employment IT specialists provide related services that are connected with software, hardware, data base, web-resources, networks and corporate systems.

The term "specialist of Information Technologies" embraces the following posts: specialist in design and testing of software, software developer, designer of computing system, project manager, system administrator, engineer of system administration, data base administrator, specialist in electric equipment, specialist of technical expertise, developer of software technical specifications ("Nacional'nij klasifikator Ukraïni", 2010). The survey of the

sites of leading Ukrainian IT companies (https://www.epam.com/; https://www.softserveinc.com/en-us/; https://www.luxoft.com/; https://www.globallogic.com/ua/; https://www.ciklum.com) allowed us to supplement the list with the following posts: specialists in support, specialist in software sales, specialist in company development, customer service specialist, HR specialist.

The list of specialties which higher educational institutions in Ukraine follow to provide training of prospective IT specialists comprises: analyst of computer system, analyst of computer database, analyst of operational and applied software, analyst of software and multimedia, computer-aided manufacturing engineer, computer system engineer, software engineer, engineer -programmer, database programmer, applied programmer, system 
programmer, specialists in information technologies, specialist in software design and testing, software developer, technician-programmer, system administration technician (Profesijnij standart 2014; Profesijnij standart fahivec' z informacijnih resursiv 2014).

IT specialists design, test, operate and maintain technical products (namely software); manage networks, administer database, analyze customers' demands, study the peculiarities of cooperation with suppliers and contractors, work out technical specifications of software, troubleshoot, provide support of software application, evaluate efficiency of the applied technological products (namely software products), implement new systems, launch new technological products (including software).

The professional duties of IT specialists envisage oral exchange of information, oral agreement and arrangement, and formal correspondence as well that coordinate business activity within the system "company-external supplier (contractor)" with the aim of information provision and high quality of technologies. Thus, a special attention is paid to written communication, since correspondence constitutes company's documents and, consequently, it should be lexically, grammatically and stylistically correctly produced. The specific character of IT specialist's work involves a great amount of correspondence in English, because external suppliers or contractors of Ukrainian IT companies are overseas companies and entrepreneurs.

\section{The essence of key concepts of the research}

In order to reveal the peculiarities of written English communication of IT specialists we will analyze the concept of communication.

Famous Ukrainian linguist F. Batsevych defines communication as a set of links and interactions of people, societies and subjects, namely classes, groups, individuals within which exchange of information, experience, abilities, skills, results of activity, reciprocal influence, behaviour correction occurs. Communication exhibits in oral and written forms (Bacevich, 2007). Afterwards verbal communication is a form of social interaction by means of language that is implemented in communicative activity of the partners ([Bacevich,2007).

The essence of English written communication consists in production of written texts in English that possesses appropriate grammatical structure, stylistic and lexical peculiarities, that include English lexical units: words, collocations, etc. (Tarnapolsky, 2008). Proceeding from the given definition we interpret a professionally oriented written communication in English of 
prospective IT specialists as the process that implies creation and exchange of English written texts with professionally oriented content that is characterized by relevant grammatical structure, stylistic and lexical peculiarities that are concerned with usage of professionally oriented vocabulary, namely IT terms. English written communication of IT specialists takes place with the aim of performing professional duties, fulfilling professional functions and roles of the specialists which hold an aforementioned post in IT sphere.

\section{Communicative situations, functions, genres, types and features of English written communication of IT specialists}

In compliance with situations of communication that are special and time circumstances in which the participants of communication exist and which prompt them to interact, guide their communicative behavior, the ways of implementing communicative intention, communicative strategies and tactics of communication are determined (Bacevich, 2007). The functions of communication comprise contact, information, inducing, cognitive, emotive, influencing and fence-mending ones (Bacevich, 2004). In reference to professionally oriented communication, a function of problem solving and assignment completion can be added to the list (Moursund, 2005, p.5). Thereafter, in the framework of the main situations of professionally oriented written communication in English of IT specialists, which are represented by business correspondence, correspondence with colleagues and chiefs, performance reports, the abovementioned functions of professionally oriented written communication in English of IT specialists are realized, namely: contact, information, inducing, cognitive, emotive, influencing and fence-mending ones.

On the basis of the analysis of functions and professional duties of IT specialists and the communicative situations of their professionally oriented written communication as well we can deduce that the genres of professionally oriented written communication in English of IT specialists include: private and business e-mail correspondence, texting in chats and forums, posting on electric announcement boards, memo, and reports. Along with it the listed genres exhibit different degrees of interactivity. Thus, email correspondence is characterized by a low degree of interactivity while texting in chats and forums are notable for an average degree of interactivity. Hence, posting on electric announcement boards, memo and reports have a low level of interactivity or its absence (Smirnov, 2009, p. 159). The main devices of production of 
professionally oriented written communication in English of IT specialists are computer and Internet.

Having analyzed the works of Manual Castells (Castells, 1992), we can outline the general features that are pertinent to professionally oriented written communication in English of IT specialists: available electronic transmission channel, mediation (communication occurs between its participants by means of technical, electronic communication facilities), remoteness (distance between the participants of communication and absence of immediate visual contact), hypertextuality (written text in network space changes and acquire hypertextual shape), virtuality (signs and symbols of computer-aided interaction), creolity ( written texts use both linguistic means and paralinguistic devices, e.g. picture, photo, symbols, colours, fonts), stylistic heterogeneity, genre diversity, relevant online etiquette (the participants of that communication have certain communicative status that is recognized, supported and implemented by an array of special tools and is regulated by special rules).

On the basis of the analysis we can deduce that the main types of professionally oriented written communication in English of IT specialists, defined by the nature of interaction and status-role relations between communicators, and also by relevant application in the field of IT business, are informal (communication with colleagues), semi-formal and formal communication (communication with suppliers, clients, chiefs), analytical and scientific communication (reports).

Informal and semi-formal professionally oriented written communication in English prevails while IT specialists perform their professional functions and duties. Professionally oriented informal written communication in English of IT specialists reflects the peculiarities of spoken informal style. Professionally oriented semi-formal written communication in English of IT specialists come closer to informal spoken style (Romashenko, 2015). Therefore informal and semi-formal professionally oriented written communication in English of IT specialists possesses the following stylistic features: large bulk of lexical units, which are found in spoken language, specific usage of first and small letters, ignorance of spelling, usage of specific abbreviations, substitute of words or their parts by homonymous letters or figures, "smiles" and emoticons. A grammatical aspect of informal and semi-formal written communication of IT specialists is represented by such phenomena as frequent omission of auxiliary verbs (everyone having a nice day), absence of subject and verb inversion or absence 
of auxiliary verb in questions (you wanna ...?), special punctuation, namely absence of apostrophe and repeated usage of a question mark and exclamation mark to render additional expressivity. A lexical aspect of informal and semi-formal written communication of IT specialists is notable for a bulk of special words and collocations, phrases and expressions related to computer terminology, especially - computer slang words. It contributes to the creation of peculiar idiolect (computer jargon)) based on specific computer vocabulary that is used as a way of self-expression of participants of communication (Dedova, 2004, p. 39-61.).

Formal written communication of IT specialists in email correspondence generally reflects the rule of epistolary genre and is characterized by the dominance of pragmatic set that is embodied in the text by a conscious communicative addressee's intention to have an effect on the addresser (Bugajchuk). Formal letters, emails are required to be concise and formal. Abbreviations of technical terminology are used to save space and time. A concise letter, email should be written in a simple and natural way, directly to the point (Shunhui Zhao, 2010). The general vocabulary, phrasal verbs, simple prepositions and conjunctions should be avoided for formal expressions that are accurate in meaning and more preferred (to advise and inform instead of to tell). As far as grammar in formal writing concerned, it isn't appropriate to use active verb forms with the first person, to leave out word, to use contractions etc. The main ideas are better developed by longer and more complex sentences which provide more details and descriptions.

Analytic scientific professionally oriented writing in English of IT specialists in the form of the report requires a certain structure, follows scientific style and certain format. It presents facts and data about the work done. The key features of analytic scientific writing are as follows: precision, clarity and objectivity. Precise concrete language and quantitative rather than qualitative descriptions are preferred in analytic scientific writing. There exist several stylistic conventions that enhance objectivity: preferred usage of passive voice, avoiding emotive words and first person pronouns (Mykytenko, Sulym, Kozolup, p. 42-44). What concerns the choice of terms, IT specialists tend to use familiar terms rather than obscure ones.

\section{Conclusion}

On the basis of the research the following conclusions are to be made. 
Higher educational institutions in Ukraine train prospective IT specialists after the following specialties: analyst of computer system, analyst of computer database, analyst of operational and applied software, analyst of software and multimedia, computer-aided manufacturing engineer, computer system engineer, software engineer, engineer -programmer, database programmer, applied programmer, system programmer, specialists in information technologies, specialist in software design and testing, software developer, technicianprogrammer, system administration technician.

Job placement of specialists of IT technologies isn't confined only to IT companies, they can work at any enterprises or organizations that use modern ICT technologies. IT specialists provide: designing, testing, operation and maintenance of technical products (namely software); networks handling, database administering, analysis of customers' demands, study of the peculiarities of cooperation with suppliers and contractors, elaboration of technical specifications of software, troubleshooting, support of software application, evaluation of efficiency of the applied technological products (namely software products), implementation of new systems, launch of new technological products (including software).

Effective execution of professional duties requires IT specialists to accomplish oral exchange of information, to conduct oral and written negotiations, to provide oral and written arrangements, and also to handle correspondence in order to coordinate business activity within the system "company-external supplier (contractor)" with the aim of information provision and high quality of technologies. We claim that special attention must be paid to written communication, since correspondence constitutes company's documents and, consequently, it should be lexically, grammatically and stylistically correctly produced. A substantial amount of correspondence is maintained in English, because external suppliers or contractors of Ukrainian IT companies are overseas companies and entrepreneurs.

Professionally oriented written communication in English of prospective IT specialist is considered as the process that implies creation and exchange of English written texts with professionally oriented content that is characterized by relevant grammatical structure, stylistic and lexical peculiarities that are concerned with usage of professionally oriented vocabulary, namely IT terms.

We refer to the main situations of professionally oriented written communication in English of prospective IT specialist: business correspondence, correspondence with colleagues 
and chiefs, performance reports. The genres of professionally oriented written communication in English of IT specialists, which are notable for different degrees of interactivity, include: private and business e-mail correspondence, texting in chats and forums, posting on electric announcement boards, memo, and reports. The main types of professionally oriented written communication in English of IT specialists, defined by the nature of interaction and status-role relations between communicators, and also by relevant application in the field of IT business, are informal (communication with colleagues), semi-formal and formal communication (communication with suppliers, clients, chiefs), analytical and scientific communication (reports). Informal and semi-formal professionally oriented written communication in English prevails while IT specialists perform their professional functions and duties. These types of professionally oriented written communication in English of prospective IT specialists possesses the following stylistic features: large bulk of lexical units, which are found in spoken language, specific usage of first and small letters, ignorance of spelling, usage of specific abbreviations, substitute of words or their parts by homonymous letters or figures, "smiles" and emoticons. The listed features contribute to the creation of peculiar idiolect (computer jargon) based on specific computer vocabulary. Formal written communication of IT specialists in email correspondence generally reflects the rule of epistolary genre and is characterized by the dominance of a conscious communicative addressee's intention to have an effect on the addresser. Analytic scientific written communication in English of IT specialists has a clear structure, follows a certain structure and form, and reflects key features of English scientific writing, namely: precision, clarity and objectivity.

The analysis of the peculiarities of professionally oriented written communication in English of prospective IT specialists will lend themselves in the foundation of content structuring within the framework of methods of building English lexical competence in professionally oriented writing.

\section{References}

Castells M. (1992) The Informational City: Economic Restructuring and Urban Development. Wiley-Blackwell.

Moursund D. (2005) Introduction to Information and Communication Technology in Education, https://darkwing.uoregon.edu/ moursund/Books/ICT/ICTBook.pdf. [accessed: 05.10.2018] 
Mykytenko N.O., Sulym V.T. Kozolup M.S. (2017) Developing Academic Literacy: EAP for Scinece Majors. Lviv. Ivsn Franko Lviv National University.

Shunhui Zhao (2010) Analysis of language features in business correspondences//Proceedings of the 2010 International conference on Information Technology and Scientific Management, file.scirp.org/pdf/20-1.76.pdf [accessed: 10.10.2018]

Bacevich F.S. (2004) Osnovi komunikativnoï lingvistiki [Basics of communicative linguistics] Kiïv: Akademija.

Bacevich F.S. (2007) Slovnik terminiv mizhkul'turnoï komunikaciï. [Glossary of Terms of Intercultural Communication], Kiïv: Dovira.

Bugajchuk K. L. Elektronnij pidruchnik: ponjattja, struktura, vimogi [Electronic textbook: concept, structure, requirements] http://www.journal.iitta.gov.ua [accessed: 15.09.2018]

Dedova O. V. (2004) O specifike komp'juternogo diskursa [On the specifics of computer discourse] // Russkij jazyk: Istoricheskie sud'by i sovremennost': tezisy. Moscow.

Romashenko V. E. (2013) Komp’juternij diskurs jak zasib formuvannja informacijnokomunikacijnoï kompetenciï bakalavriv filologï [Computer discourse as a means of formation of information and communication competence of bachelors of philology],

www.irbis-nbuv.gov.ua/cgi../cgirbis.64exe? [accessed: 15.09.2018]

Smirnov F. O. (2009) Iskusstvo obshhenija v Internete [The art of communication on the Internet]. Moscow: Williams Publishing House.

Tarnapolsky O. B. (2008) Metodika navchannja studentiv vishhih navchal'nih zakladiv pis'ma anglijs'koju movoju [Methodology of teaching students of higher educational establishments writing in English]. Vinnitsa: Nova Kniga.

CIKLUM https://www.ciklum.com [accessed: 01.07.2018]

EPAM https://www.epam.com/ [accessed: 01.07.2018]

GLOBAL LOGIC https://www.globallogic.com/ua/ [accessed: 01.07.2018]

LUXOFT https://www.luxoft.com/ [accessed: 01.07.2018]

SOFTSERVE https://www.softserveinc.com/en-us/[accessed: 01.07.2018]

Nacional'nij klasifikator Ukraïni DK 003:2010 «Klasifikator profesij» [National Classifier of Ukraine DK 003: 2010 "Classifier of Occupations"] (2010)

http://zakon.rada.gov.ua/rada/show/va327609-10\#n4 [accessed: 04.08.2018]

Profesijnij standart [Professional standard] (2014)

https://mon.gov.ua/storage/app/media/vyshcha/IT-prof-standarty/6-ps-rozrobnik-pz13.12.2014.pdf [accessed: 01.08.2018]

Profesijnij standart fahivec' $z$ informacijnih resursiv [Professional standard is a specialist in information resources] (2014), https://mon.gov.ua/storage/app/media/vyshcha/IT-profstandarty/4-ps-spes-inform-resources-13.12.2014.pdf [accessed: 01.08.2018] 


\section{Translation of the References to the Author's Language}

Castells M. (1992) The Informational City: Economic Restructuring and Urban Development. Wiley-Blackwell.

Moursund D. (2005) Introduction to Information and Communication Technology in Education, https://darkwing.uoregon.edu/ moursund/Books/ICT/ICTBook.pdf. [accessed: 05.10.2018]

Mykytenko N.O., Sulym V.T. Kozolup M.S. (2017) Developing Academic Literacy: EAP for Scinece Majors. Lviv. Ivsn Franko Lviv National University.

Shunhui Zhao (2010) Analysis of language features in business correspondences//Proceedings of the 2010 International conference on Information Technology and Scientific Management, file.scirp.org/pdf/20-1.76.pdf [accessed: 10.10.2018]

Бацевич Ф.С. (2004) Основи комунікативної лінгвістики. Київ: Академія.

Бацевич Ф.С. (2007) Словник термінів міжкультурної комунікащії. Київ: Довіра.

Бугайчук К. Л. Електронний підручник: поняття, структура, вимоги, http://www.journal.iitta.gov.ua [accessed: 15.09.2018]

Дедова О. В. (2004) O специфике компьютерного дискурса // Русский язык: Исторические судьбы и современность: тезисы. Москва.

Ромашенко В. Є. (2013) Комп'ютерний дискурс як засіб формування інформаційнокомунікаційної компетениії бакалаврів філології

www.irbis-nbuv.gov.ua/cgi../cgirbis.64exe? [accessed: 15.09.2018]

Смирнов Ф. О. (2009) Искусство общзения в Интернете. Москва: Издательский дом Вильямс.

Тарнапольський О. Б. (2008) Методика навчання студентів вищих навчальних закладів письма англійською мовою. Вінниця: Нова Книга.

CIKLUM https://www.ciklum.com [accessed: 01.07.2018]

EPAM https://www.epam.com/ [accessed: 01.07.2018]

GLOBAL LOGIC https://www.globallogic.com/ua/ [accessed: 01.07.2018]

LUXOFT https://www.luxoft.com/ [accessed: 01.07.2018]

SOFTSERVE https://www.softserveinc.com/en-us/[accessed: 01.07.2018]

Національний класифікатор України ДК 003:2010 «Класифікатор професій» (2010), http://zakon.rada.gov.ua/rada/show/va327609-10\#n4 [accessed: 04.08.2018]

Професійний стандарт (2014) https://mon.gov.ua/storage/app/media/vyshcha/IT-profstandarty/6-ps-rozrobnik-pz-13.12.2014.pdf [accessed: 01.08.2018]

Професійний стандарт фахівець з інформаційних ресурсів (2014),

https://mon.gov.ua/storage/app/media/vyshcha/IT-prof-standarty/4-ps-spes-inform-resources13.12.2014.pdf [accessed: 01.08.2018] 


\title{
Ways of Improvement of Pedagogical Skill of Commanders
}

\author{
Abdurakhmanov Sherzod, \\ Safayev Husen \\ Teachers of military department of the Bukhara state university
}

\begin{abstract}
The significant role in formation and development of pedagogical skill of the sergeant (foreman) belongs to active inclusion in pedagogical activity of creativity. The efficiency of process of formation and development of pedagogical skill in many respects is defined also by work of the junior commander on self-improvement.

Keywords: pedagogical skill, training process, pedagogical observation, pedagogical insistence, commander, sergeant, psychology and pedagogical preparation.
\end{abstract}

For years of Independence in Uzbekistan the steady system of receiving education by the population which originates in preschool educational institutions and comes to the end at the level of academies is built. Military education is an important component of this harmonious system.

Military education makes the powerful contribution to implementation of the National program of training of the Republic of Uzbekistan. Adoption of such document once again demonstrates that training high quality is brought in our country to the level of state policy. And it bears fruits.

The task to realize a package of measures for further development of a uniform multilevel system of the training of junior commanders providing comprehensive updating of activity of schools of training of sergeants in full accordance with new modern requirements is set. Professionally prepared non-commissioned officer's structure not in words, and in practice has to become a support and a core of our army on which the moral and psychological and moral situation in each military collective in many respects depends.

Knowledge junior commanders of a pedagogical entity, contents and features of the organization of training activity and education of the military personnel helps them thoughtfully and to creatively solve problems of training and education of subordinates, to systematize and arrange the activity, to carry out it is pedagogically reasonable and assured to achieve goals.

Content of training of soldiers in parts and divisions is determined by curricula and programs. It is aimed at training of the military specialists meeting the requirements which are imposed by our state to defenders of the Fatherland. In this regard tasks are set for training activity: arm soldiers with the system of versatile knowledge, develop at them necessary skills and abilities, to create high moral and psychological and fighting qualities, to develop intellectual and physical forces, to prepare psychologically for military professional activity. In it the multifunctionality of this process is shown.

On the structure process of training represents the interconnected activity of training (commander) who various means of pedagogical influence and interaction has an impact on 
mentality of the military personnel and trained (soldiers) - they actively react to its influences, seizing at the same time certain knowledge, skills and abilities. Thus, both parties of process are indissoluble and active.

Training, stating a training material in the systematized look and showing the most expedient methods of practical work, psychologically trains trainees for perception of the studied material, develops at them cognitive and professional interest to a subject; improves abilities and ability to independently acquire knowledge, to seize professional skill; analyzes work of trainees and controls assimilation of knowledge, skills and abilities. At the solution of this complex of the interconnected tasks training acts first of all as the organizer of educational activity. At the same time it performs also function of the tutor.

The significant role in results of training and education is played by pedagogical skill of the sergeant (foreman) which acts as a rod component of pedagogical culture of training. It in many respects characterizes the professional and moral level of the sergeant (foreman).

The pedagogical skill represents the system of knowledge, skills and abilities, ways of thinking, emotional means of expressiveness which in interaction allows it to solve teaching and educational problems with advanced pedagogical personal qualities of the teacher successfully.

In the structural relation join in pedagogical skill: pedagogical equipment, erudition, observation, imagination, thinking, insistence, step and also standard of speech.

The pedagogical technology is a complex of various skills and abilities, receptions and means by means of which the sergeant (foreman) reaches efficiency of application of methods of pedagogical impact on certain trainees and on collective in general. In the most general view the pedagogical equipment includes:

a) skills and abilities in the organization of studies;

b) methods of expressive display of the relation, feelings to these or those actions of trainees, technology of the speech;

c) "technology" of studying and accounting of specific features of the personality, psychology and pedagogical features of collectives;

d) skills and abilities in mastering technical means of training and other means of presentation;

e) pedagogical account and control of education and good training of the military personnel.

The pedagogical erudition of the sergeant (foreman) is shown in free possession of fundamentals of psychology and pedagogics, ability to carry out the psychology and pedagogical analysis of offense, the fact, "phenomenon" to define concrete measures of pedagogical influence, effective forms, methods. means of teaching and educational work.

The pedagogical observation of the sergeant (foreman) includes the following abilities: to watch systematically behavior and activity of trainees; to determine by insignificant signs of feature of interior, his experience and mood, to notice all happening changes.

The pedagogical imagination assumes: 
a) ability of the junior commander to mentally present inner world of the military personnel;

b) ability correctly, clearly and lively to define the possible factors affecting behavior of the trainee and on his attitude towards surrounding reality;

c) ability to expect various options of behavior of trainees in this or that situation, under the influence of this or that factor, means;

d) ability to present and plan the main actions, the actions for training, education or reeducation of subordinates.

Pedagogical thinking of the sergeant (foreman) is characterized by his ability:

a) to quickly analyze the behavior, behavior of trainees, their relation to work, to allocate basic elements and signs in behavior of each trainee and collective in general;

b) to synthesize, to mentally establish connection, to unite the separate moments in the activity and activity of trainees, in their relation to educational process;

c) to compare separate elements in behavior of the military personnel, to define similarity and differences in each pedagogical situation;

d) to draw the correct conclusions from the activity and to give an objective assessment to actions, knowledge of trainees.

The following features of the speech have to be inherent in the sergeant (foreman): high culture; pithiness and harmonious development in all its types; highly moral relation to a word - fidelity to this promise, responsibility of statements; possession of speech emotional means of expression (intonation, speed, expressiveness, timbre, mimicry, gesticulation, etc.).

Pedagogical insistence as the many-sided, generalized quality of the sergeant (foreman) is shown first of all in his attitude towards surrounding people and also towards itself. Using insistence as an educational tool, it is necessary to remember that it has to proceed from the interests of business, to be a constant, to extend to all members of collective equally and to be combined with respect of personal dignity of trainees, with insistence to itself.

The pedagogical step is the difficult professional quality of the sergeant (foreman) which is characterized by pedagogically expedient measure of his relations with trainees and impacts on them in a concrete situation. The pedagogical step is possible only at the most sincere respect of subordinates. An important condition of its manifestation is the ability to be self-controlled and to observe pedagogically expedient measure in application of teaching and educational influence.

The considered qualities in their unity and interconditionality are that basis on which the skill of the sergeant (foreman) as the teacher and the tutor of the military personnel is formed and improved.

Thus, during formation and development of pedagogical skill the sergeant (foreman) needs to develop at himself certain qualities, knowledge, skills and abilities, to improve those parties of the personality which play a crucial role in growth of skill of the teacher. Along with development of personal qualities of the teacher it is necessary to improve the psychology and 
pedagogical preparation, to join actively in daily pedagogical activity, work on improvement of the main components of pedagogical skill.

\section{References}

1. Yenikeev M.I. Obshhaja i social'naja psihologija. [General and social psychology.] - M.: TK Velbi, Prospect, 2007.

2. Karayani A. G. Prikladnaja voennaja psihologija : uchebno-metodicheskoe posobie : (uchebnoe posobie dlja kursantov i slush. vyssh. voen.-ucheb. zavedenij) [Applied military psychology: educational and methodical manual: (manual for cadets)] / A.G. Karayani, I.V. Syromyatnikov. - SPb. [etc.]: St. Petersburg, 2006.

3. Yurchenko Yu. Puti $i$ sposoby povyshenija kachestva vospitatel'nogo processa $v$ podrazdelenii [Ways and methods of improvement of quality of educational process in division] // Oriyentir. - 2006. - No. 7.

\section{Translation of the References to the Author's Language}

\section{Литература}

1. Еникеев М.И. Общая и социальная психология. - М.: ТК Велби, Проспект, 2007.

2. Караяни А. Г. Прикладная военная психология : учебно-методическое пособие: [учебное пособие для курсантов и слуш. высш. воен.-учеб. заведений] / А. Г. Караяни, И. В. Сыромятников .-СПб. [и др.] : Питер, 2006.

3. Юрченко Ю. Пути и способы повышения качества воспитательного процесса в подразделении // Ориентир. - 2006. - № 7. 


\title{
The Issue of Civic Education of a Person in the Pedagogical Heritage of Olexander Stronin
}

\author{
Vadim Pilipenko \\ postgraduate student of the Poltava National University \\ Pedagogical University named after V.G. Korolenko, Ukraine
}

\begin{abstract}
Summary
The article highlights the views of O. Stronin on the problem of civic education of the individual. The key elements of the formation of personal virtues are revealed. It was shown that the teacher saw the key source of civic education of the individual as decent examples of the actions of people of the past and present.
\end{abstract}

Keywords: O. Stronin, civic education, personal example.

The development of civil society is inextricably linked with the upbringing of the individual. Therefore, in addition to important changes in the political and economic spheres, in the forefront of reform in public life based on the principle and humanism, democracy and human rights. The leading role in inculcating the values of the people in modern society belongs to the education sector. The Preamble of the Universal Declaration of Human Rights states that by implementing basic document is education and education that should promote the protection of human rights and freedoms through national and international progressive measures [1].Despite some progress, the system of civic education needs to be improved.

The need for realization of this task pays attention to historical and pedagogical experience. In view of this, I would like to pay special attention to the extraordinary figure in the development of the nineteenth century education, the teacher, scientist, activist of the communist movement in Ukraine Oleksandr Ivanovich Stronin. After all, it was he who was one of the first in the Russian Empire to draw attention to the need to return the educational process to the cutting edge of the civic values of the individual.

The purpose of this article is to thoroughly analyze the place of civic education in the educational activities and pedagogical views of Olexander Ivanovich Stronin. 
Olexander Ivanovich Stronin (1826-1889) lived and worked in very turbulent times. As a result of the Industrial Revolution, the Russian Empire completely plunged into the progressive development of capitalism. The society was on the verge before deep changes. Olexander Ivanovich, being a remarkable intellectual of his time, could not stay away from these processes. Therefore, he became an active champion of new ideals from an early age.

Childhood O. Stronin was in frequent transitions from place to place. The reason for the latter was the service of his father, who, although he was a serf and due to his literacy, was able to become the ruler of the princely estates of the genus Yusupov. I. Stronin had a positive influence on his three sons. From the very beginning, teaching them to reading, he laid the foundation for the future formation of sons as intelligent personalities. The father was able to achieve his free sons and sent them to study. Indicative is the fact that all three sons of I. Stronin subsequently became teachers [4, p.25].

O. Stronin first studied at Priluky District School. After getting free, he continued his studies at the Second Kyiv Gymnasium. In the pursuit of the study of the foundations of building a civil society, In 1845 O. Stronin became a law student at Kiev University St. Volodymyr. Being a well-educated man, Olexander Ivanovich received an extraordinary disappointment from the then lawyers and on the second course of study he transferred to the Faculty of History and Philology [2, p.144]. It has played a key role in choosing a teacher's profession in the future.

O. Stronin's professional formation took place under difficult circumstances - a young, creative teacher could not find himself in the system of conservative education of the middle of the XIX century in the Russian Empire. Therefore, it does not seem surprising that in the first six years of work the teacher changed four educational institutions.

In search of a comfortable environment for self-realization O. Stronin got to the First Poltava Gymnasium. We would like to emphasize that at that time Poltava became the focus of the progressive Ukrainian intelligentsia, which directed its efforts to overcome the total illiteracy that prevailed among the general population. O. Stronin, interacting with the educational and cultural figures of Poltava, as well as attracting patrons from the local gentry, joined the creation of free Sunday schools for the poor, public lectures, public theater, etc. It is important that the teacher himself developed teaching programs, educational literature 
and methodological recommendations for teachers involved in such forms of educational volunteering.

As you can see, O. Stronin 's educational activity was full of desire to be useful for raising the general educational level of society, serving as proof of a clear teacher's civic position. Along with this, the teacher, on the basis of his practical experience, developed a significant theoretical basis, which resulted in the scientific and pedagogical heritage of O. Stronin. Among the issues studied by the teacher, the problems of becoming an educated citizen as an important element of society's development are important. Proceeding from the above, it is important to study the views of O. Stronin on the problem of civic education.

O. Stronin was convinced that the full formation of an enlightened citizen gives him the opportunity to constantly develop. For society, the benefit was that a fully developed person with implanted civil values should become the basis for a stable economic and political development of the state [5, p. 44].

With great expectations for young people in building a new society, O. Stronin emphasized the priority of civic education. After all, it was the citizen who was supposed to take responsibility for creating a new socio-political system. He should have a decent education, be a native of the intelligentsia, and must have a high level of self-awareness, that is, embody the ideal of an enlightened person from the educational concept of a teacher.

The leading source of civic upbringing of personality for O. Stronin were examples of deeds of decent people. He believed that the very personal example most influences the pet, stimulates it to self-development. But, looking for such biographies, the teacher faced unexpected difficulties. In particular, for most European countries, the belonging of the people's heroes to the noble dynasties is characteristic. Thus, educator cited examples of European aristocratic families Warwick, Northumberland, Norfolk, Monforte, Pembroke who became the embodiment of the national spirit for in middle class [6, s.399]. After all, these families, embodying a struggle with kings, an aristocratic pride, carry the revolutionary spirit [6, p.399]. By analogy with Russian aristocrats, the teacher drew attention to the fact that among them a truly educational influence on the awakening of the civil spirit can only have the biographies of A. Kurbsky and Metropolitan Philip [6, p.399]. In the prince A. Kurbsky O. Stronin personified the first Russian dissident, a fighter for freedom, a person with high 
moral qualities, able to provide a good example for pupils as a fighter with royal tyranny. He loved his homeland and brought her military power, but was forced to leave her through a tyrannical king. His work could serve as an example for civic values, but here the teacher emphasized that active polemics were initiated by the prince already when he was in the Commonwealth [6, p. 399]. The use of educational effects of biographies in this case became problematic.

Causes of a limited number of heroic examples among Russian aristocrats O. Stronin was associated with the communal consciousness of the population. Personal heroism, according to the teacher, was always in the shadow of the mass [6, p. 399]. Thus, the educator emphasized the lack of an individualistic civil feeling through the influence on him of a public reflex, which undermined not only general principles in social education, but also negatively influenced the civic- patriotic attitude in society.

A special place in the system of views of O. Stronin's civic education of personality took manifestations of social solidarity and patriotism. In particular, in the "Anecdotal History of the Current War", the teacher noted with enthusiasm that there was a large number of volunteers among medical students who, with the onset of the Russo-Turkish War, entered the Red Cross "[3, p. 2]. The teacher described the true impulse of youth to help their homeland, who was in a state of war with a strategic enemy.

With particular respect the teacher spoke about the well-known philosopher-positivist G. Virubov, who, although he had French citizenship, but decided to volunteer to protect his "natural homeland", arrived in the Caucasus, began active activities aimed at the plunder of male hospitals [3, p.3]. So, in the pedagogical views of O. Stronin, one of the leading sources of influence on the personality in order to spread civil ideals, was an example of human actions as a direct manifestation of the value beliefs of the individual.

Thus, having analyzed the problem of civic education in the pedagogical heritage of O. Stronin, we have a solid foundation to state that it was based not on the theoretical principles of civicism or humanism, but a very real example of the life of well-known personalities. The teacher emphasized the importance of reporting to the younger generation the importance of seeking examples of social ideals among existing people, which certainly exist for every nation, but they may simply be little known. Such "worthy citizens" at the same time were an 
inexhaustible source of civil virtues and direct " methods of their implementation" through a personal example.

\section{References}

1. Zagal'na deklaracija prav ljudini [Universal Declaration of Human Rights] / http://zakon.rada.gov.ua/cgi-bin/laws/main.cgi?nreg=995_015

2. Svetlenko S. Narodolyubets [Patriot] O. Stronin / S. Svetlenko // Kyi'vs'ka starovyna [Kiev an antique] - 2002 . - No. 6 . - P. 143-155.

3. Stronin A. Anekdotycheskaja ystoryja tekushhej vojny [Anecdotal History of the Current War] / A. Stronyn. - With Pb : type. F. Sushchinsky, 1877 . - 48 s.

4. A. Stronyn. Dnevnyk s 1848 po 1888 gody. [Diary from 1848 to 1888 years.] - V. 1 (18631864): [1 st variant, where a lot corrections ] // Russian National Security Council St. Petersburg - f. 752. - d. 3. - 47 s.

5. Stronin A. Rasskazy o carstve Bovy Korolevycha. [Stories about the kingdom of Bovy Korolevich] / A. Stronin : [Soch.] Alexander Ivanova [ pseud .] With Pb : type. F. Sushchinsky, 1873 . $-48 \mathrm{~s}$.

6. Stronin A. Posleslovye: polytycheskaja dyagnostyka y prognostyka $v$ Rossyy [Postwords : political diagnostics and prognosis in Russia] / A. Stronin // Polytyka kak nauka [Politics as science] / St. Petersburg: St. Petersburg: type. F. Sushchinsky, 1872. - P. 329-530. 


\title{
Determination of Theoretical and Methodological Principles of Teaching Multimedia Arrangement of Future Music Teachers in the Process of Professional Training
}

\author{
Stepanov Volodymyr \\ ORCID ID https://orcid.org/0000-0002-3018-4483 \\ Postgraduate student \\ Dragomanov National Pedagogical University (Ukraine, Kyiv)
}

\begin{abstract}
In the article the importance of professional training of students in order to ensure a comprehensive readiness for future pedagogical activities is actualized. The researches of scientists concerning the professional training of future music teachers are analyzed and summarized. It is noted that the professional training of future music teachers is focused on the modernization and optimization of the educational process. The interpretation of the concept of theoretical and methodical principles is researched and our own interpretation of the concept of «theoretical and methodical principles of teaching multimedia arrangement of future music teachers» is given. The basic components of theoretical and methodical principles of teaching multimedia arrangement of future music teachers in the process of professional training: scientific approaches, principles and methods are determined. The issue of integration of musical-performing disciplines as an optimal organization of the pedagogical process on the basis of inter-subjective interaction is emphasized. The essence of the methodology of teaching multimedia arrangement of future music teachers is defined, the main directions of educational work which will affect the quality of their professional training in general are outlined.
\end{abstract}

Key words: professional training, theoretical and methodological principles, integration, training of multimedia arrangements, future music teachers.

Актуальність досліджсення. У відповідності до нових вимог сучасності актуалізуються питання фахової підготовки майбутніх учителів, яка в контексті реформування освіти, спрямованого на подолання протиріч між традиційними формами й методами навчання та новими можливостями, що пов'язані $з$ появою нових форм інформації, нового освітнього середовища [5], потребує розроблення i впровадження нових підходів до методики навчання студентів з метою забезпечення всебічної готовності до майбутньої педагогічної діяльності.

У контексті нашого дослідження метою даної статті визначено розгляд теоретико-методичних засад навчання мультимедійного аранжування майбутніх учителів музики в процесі фахової підготовки.

Виклад основного матеріалу. Визначення поняття «підготовка» спирається на досвід системного дослідження освіти та педосвіти як складноорганізованих 
соціокультурних феноменів і пов'язано 3 науковими доробками В. Андрущенка, Г. Балла, Б. Гершунського, О. Глузмана, В. Лугового, О. Олексюк, О. Шевнюк та ін.. Варто зауважити, що сучасні стандарти вищої освіти акцентують увагу на інтеграції навчальних дисциплін, що вимагає розроблення теоретичних i практичних засад моделювання дидактичного процесу, його інформатизації, з'ясування механізму реалізації взаємозв'язків між дисциплінами з урахуванням професійної спрямованості в ході добору їхнього змісту [7, с. 4].

Інтеграцію мистецтв у фаховій підготовці майбутніх учителів музики розглянуто Г. Бродським, О. Рудницькою, О. Хижною, І. Шевченко. Питання реалізації міжпредметних знань розглянуті Л. Варнавською, Т. Латишевою. Питання інтеграції музично-теоретичної підготовки досліджували О. Комаровська [13], І. Малашевська, Г. Побережна, Т. Щериця, Ю. Локарєва. Інтеграцію музично-виконавської підготовки розглядали В. Лабунець, Ж. Карташова, С. Проворова, О. Щолокова [12; 14].

Науковими дослідженнями останніх років (О. Барицька, Л. Варнавська, Л. Гаврілова, Ю. Дворник, В. Луценко, Л. Масол, Н. Новікова, Н. Сушкевич, В. Шинкаренко, О. Чайковська, М. Чембержі та ін.) доведено, що використання мультимедійних технологій уможливлює застосування нових методів, форм та засобів організації навчальної діяльності. Під поняттям «мультимедійні технології» науковці розуміють комплекс інформаційних технологій (Н. Новикова), велику «галузь знань, що інтегрує елементарну теорію музики, сольфеджіо, ансамбль, оркестр, вокальне мистецтво, аранжування, читання оркестрових партитур, інструментування й можливості сучасних комп'ютерних технологій» [11, с. 338].

Визначення мультимедійної технології як технології, що «окреслює порядок розробки, функціонування та застосування засобів обробки інформації різних модальностей» та мультимедійного уроку, «на якому використовують багатосередовищне подання інформації за допомогою технічних засобів, перш за все комп'ютера» подані М. Ляшком [3, с.101; 14; 15; 16].

У довідникових джерелах знаходимо декілька значень поняття «засада», серед яких: «основа чогось» (тобто, те, на чому щось базується), «вихідне, головне положення, принципи» і спосіб, метод здійснення чого-небудь» [1, с. 41]. Методика навчального предмета досліджує закономірності вивчення предмета i включає 
вироблення методів, методичних засобів і організаційних форм навчання (відповідно до змісту і завдань), а у вузькому розумінні - учення про методи навчання [8, с. 20]. Поняття «теорія» в Українському педагогічному словнику трактується як «сукупність ідей, поглядів, концепцій, вчень, уявлень про об’єктивну дійсність». Практична діяльність «осмислюється, організовується, спрямовується теорією» [8, с. 328].

Отже, теоретико-методичні засади навчання мультимедійного аранжування майбутніх учителів музики розуміємо як сукупність вихідних концептуальних положень щодо обгрунтування і визначення основоположних принципів, методів, форм навчання мультимедійного аранжування, визначених науковими підходами.

Навчання мультимедійного аранжування ми розуміємо як активний умотивований процес інтегрованої взаємодіі навчально-пізнавальної, практичної музично-творчої діяльності, спрямованої на створення нового якісного продукту аранжування музичного твору - на основі узагальнення теоретичних знань, збагачення практичного (слухацького) досвіду та оволодіння засобами мультимедіа. Очевидно, що якість фахової підготовки майбутніх учителів музики в наш час великою мірою залежить саме від оволодіння сучасними освітніми мультимедійними технологіями.

Через що, виникає необхідність розробки методики навчання мультимедійного аранжування майбутніх учителів музики, що позначиться на якості їхньої фахової підготовки у цілому. Сутність методики полягає у підтримці мотивації до навчання мультимедійного аранжування, актуалізації музично-теоретичних знань і практичнотворчих умінь, розвитку навичок отримання інформації з різних джерел (Інтернет включно), умінь використовувати засоби мультимедіа у процесі створення творчого продукту (аранжування музичних творів), оскільки їх застосування суттєво розширює межі музично-творчої діяльності вчителя музики і відкриває нові можливості для фахової самореалізації в інформаційному суспільстві.

Основу авторської методики становлять визначені нами напрямки роботи. Першим $\epsilon$ спрямування на набуття слухацького досвіду, розвитком у студентів музичного слуху (гармонічного, поліфонічного, тембрового, внутрішнього), здатності знаходити, відчувати, розуміти структурні елементи музичної мови, стиль, жанр, епоху, особливості творчого почерку композитора, на закріплення інтегрованих знань, умінь i навичок з теоретичних дисциплін. 
Наступний напрямок забезпечує розвиток музично-інтонаційного, образноасоціативного, поліфонічного, креативного мислення студентів, навичок імпровізації, самоаналізу, самооцінювання, самокритики та саморозвитку, формування музичноестетичного смаку. Наступні два напрямки роботи спрямовано на отримання знань, умінь і навичок щодо усіх видів аранжування (інструментовки, оркестровки, обробок тощо) та роботи з комп’ютерними програмами, спираючись на набутий у процесі опанування дисципліни «Музична інформатика» досвід.

Складовими методики виступили такі методи навчання: словесні (акроматичні та діалогічні (евристичні) методи навчання, зокрема, евристична бесіда, спрямована на розвиток музично-творчого, образно-асоціативного мислення студентів; лекції, в тому числі: лекція-екскурсія (віртуальна), лекція-візуалізація); наочні (наочно-слуховий та наочно-зоровий); інтерактивні («мозковий штурм», метод безперервної шкали думок, створення пошукових ситуацій, метод проектів); дієво-практичні (метод творчих завдань, метод інтроспекції, презентацій готового мультимедійного продукту), методи аналітично-мисленнєвої діяльності (аналізу, синтезу, порівняння, метод асоціацій, пізнання та художнього сприйняття, герменевтичного аналізу, висновків, узагальнення), методи оцінки і стимулювання (що включають самооцінку), створення ситуацій успіху, самоконтролю.

Означена методика потребує опори на особистісний, аксіологічний, акмеологічний, компетентнісний, діяльнісний підходи та герменевтичний як базисний. Аранжування музичного твору потребує від студентів детального вивчення музичного тексту, власна інтерпретація якого має бути кінцевим результатом їхньої творчої роботи. Тому у навчанні аранжуванню майбутніх учителів музики великого значення набуває герменевтична методологія, зокрема, принцип герменевтичного кола, екзистенційні діалоги, емпатійне проникнення у світ іншої людини, саморозуміння тощо. Серед особливостей герменевтичної методології необхідно підкреслити пї діалоговий характер. Отже, герменевтика як теорія розуміння та інтерпретації музичних творів $є$ методологічною основою навчання майбутніх учителів музики аранжуванню у процесі фахової підготовки.

Цілісний розвиток особистості, суб’єкт-суб'єктні взаємовідносини у процесі навчання забезпечуються з позицій особистісного підходу. Особистісний підхід у 
процесі навчання мультимедійного аранжування забезпечує створення відповідних умов для діагностики, а потім і ефективного розвитку творчого потенціалу особистості, враховуючи різнорівневу інформаційну та музичну підготовку студентів, загальний рівень освіченості, сформованості в них художнього смаку.

Аксіологічний підхід характеризується ставленням до майбутньої професії, розумінням ціннісних орієнтирів обраної професії (що передбачає сформованість ціннісно-світоглядних мистецьких орієнтацій), наявністю потреби стати кваліфікованим викладачем-музикантом (який зможе створити, за необхідності, власне художньо якісне аранжування музичного твору), наявністю потреби вдосконалювати фахову компетентність. Формування цих якостей сприяє активному та ефективному, постійному саморозвитку особистості, iï прагненню до самовдосконалення та самоактуалізації, що визначається акмеологічним підходом, завдяки якому майбутній вчитель музики спрямовується на «прогноз якісного результату в його підготовці до практичної діяльності, ... на вивчення акмевершин у музично-педагогічній роботі, на проектування методичних моделей професійної діяльності» [9, с. 4-5].

Зважаючи на те, що на сучасному етапі дещо змінюється розуміння ролі знань завдяки компетентнісному підходу до освіти (знання підпорядковуються умінням), навчання мультимедійного аранжування студентів вважаємо за необхідне розглядати 3 позицій компетентнісного підходу, актуалізуючи проблему формування фахових компетентностей, серед яких в межах нашого дослідження виділяємо інформаційну та музично-естетичну компетентності. У зв’язку з цим, виникає необхідність опори на діяльнісний підхід до навчання мультимедійного аранжування, при якому знання стають не метою навчання, а його засобом: знання засвоюються не для підвищення ерудиції, а для того, щоб здійснювати діяльність (Г. Атанов).

Зміна освітньої парадигми вимагає відображення в спрямованості професійного розвитку майбутнього вчителя, перегляду пріоритетів, що лежать в основі змісту мистецької освіти, що породжує необхідність концептуального переосмислення, подолання інертності навчально-виховного процесу у вищій школі, зазначає О. Хижна, вбачаючи розв'язання цієї проблеми в переосмисленні традиційного підходу до навчально-виховного процесу, зокрема, переосмисленні принципів [10]. 
Оскільки принципи, як основні положення будь-якого навчання, в тому числі і музичного, визначають сутність, зміст, провідні вимоги до взаємодії викладача та студентів, розділяючи думку О. Хижної, у контексті навчання мультимедійного аранжування, вважаємо за важливе дотримуватися загально-дидактичних та специфічних принципів навчання з опорою на останні.

Одним з основоположних виділяємо принцип музично-естетичного спрямування навчання. Музично-естетична спрямованість охоплює увесь зміст роботи: від формування позитивної мотивації навчальної діяльності до створення власного творчого продукту. Естетичні потреби особистості, що спрямовують на свідоме та глибоке розуміння музичного мистецтва, виступають основним мотивом навчальної діяльності в цій галузі.

Дотримання принципу діалогізації $є$ важливим, оскільки діалогічність у особистісному спілкуванні створює умови для творчих взаємовідносин. За своєю сутністю музичне мистецтво діалогічне (О. Олексюк, О. Рудницька та ін.) Мета такого діалогу створити цілісне розуміння музичного твору. Специфіка навчального діалогу визначається цілями, умовами та обставинами взаємодії.

Принцип урахування індивідуальних особливостей у застосуванні колективних форм роботи характеризує діяльність викладача й звернений до процесу навчання мультимедійного аранжування, як і будь-якого навчання, з виявленням особливостей навчання та розвитку кожного студента, спостереження за засвоєнням змістового музичного матеріалу та його творчим застосуванням. Важливим $\epsilon$ дотримання принципу акмеологічного супроводу студента в його духовному становленні, підпорядкованому постійному особистісному зростанню, та принципу індивідуального підходу з урахуванням різнорівневої музично-теоретичної підготовки та слухацького досвіду студентів (щодо інтерпретації музичних творів).

У ході експериментальної роботи ми дотримувалися також принципу відповідності творчих завдань змісту та об’єму навчальної діяльності, що передбачає уміння застосовувати інтегровані знання з музично-теоретичних дисциплін та засоби мультимедіа у практичній діяльності з метою формування практично-фахових умінь та навичок, та принцип творчої самореалізації особистості. 
Велике значення мають пов'язані між собою принципи організації навчального процесу з акцентом на самоосвіту студентів; спрямованості на їх інтелектуальний розвиток. Виокремленні нами принципи базуються на закономірностях музичнопедагогічної освіти, відображають внутрішню сутність процесу навчання мультимедійного аранжування.

Висновки. Отже, визначення оптимальних теоретико-методичних засад навчання мультимедійного аранжування майбутніх учителів музики сприяє вирішенню однієї з головних суперечностей між якістю знань в контексті традиційного підходу до змісту фахової підготовки майбутніх учителів музики, рівнем практичних умінь, яких вимагає від фахівця майбутня музично-педагогічна діяльність та освітніми завданнями розвитку і становлення творчої особистості майбутнього вчителя музики.

\section{References}

1. Velykyi tlumachnyy slovnyk suchasnoyi ukrayins koyi movy [Great explanatory dictionary of modern Ukrainian language] (z dod. i dopov.) / uklad. i holov. red. V.T. Busel. Kyiv: Irpin': VTF «Perun», 2005. 1728 p.

2. Yeremenko O.V. Teoriya i metodyka pidhotovky mahistriv muzychnoho mystetstva $v$ pedahohichnykh universytetakh [Theory and methodology of preparation of masters of musical art in pedagogical universities]: avtoref. dys. na zdobuttya nauk. stupenya dokt. ped. nauk: spets. 13.00.02 - Teoriya ta metodyka muzychnoho navchannya. Kyiv: NPU imeni M.P. Dragomanova, 2010. 45 p.

3. Lyashko M. Mul'tymediyni tekhnolohiyi yak innovatsiyna skladova muzychnoho navchannya i vykhovannya [Multimedia technologies as an innovative component of musical education and upbringing]. Humanitarnyy visnyk, 2014. No 33. P. 96-110.

4. Petko L.V. Vykhovnyi potentsial metodu sytuatsiinoho analizu ("Case study» method) u formuvanni profesiino oriientovanoho inshomovnoho navchalnoho seredovyshcha $v$ umovakh universytetu [Educational potential of the «Case study» method for the forming of the professionally oriented foreign language teaching environment in the conditions of university]. Naukovyi chasopys NPU imeni M.D.Drahomanova. Seriia 17. Teoriia i praktyka navchannia ta vykhovannia : zb. nauk. pr.;Kyiv: Vyd-vo NPU imeni M.P.Drahomanova, 2015. Issue 27. P. 133-140.

5. Petko L.V. Informatsiyno-navchalne seredovische yak umova formuvannya profesiyno orientovanogo inshomovnogo navchalnogo seredovischa v umovah universitetu [Information and teaching environment as a condition of professionally oriented foreign language teaching environments formation in the terms of the university]. Informatsiyni tehnologiyi u profesiyniy diyalnosti: Tr. IX Vseukrayinskoyi nauk.-prakt. konf., Ryvnenskiy derzhavniy gumanytarniy un-t, 25 bereznya 2015 r. Ryvne, 2015. P. 89-91. 
6. Petko, L. V. Filmy inozemnoiu movoiu u formuvanni POINS dlia studentiv-biolohiv [The foreign-language films in forming professionally oriented foreign language learning environment for students in Biology]. Krytychnyi pidkhid u vykladanni pryrodnychykh dystsyplin : materialy Mizhnarodnoi naukovo-metodychnoi konferentsii, 14 lystopada 2018 roku / ukl.: O.P. Halai [ta in.]. Kyiv: Vyd-vo NPU imeni M. P. Drahomanova, 2018. P. 118-124.

7. Timets' O.V. Teoriya $i$ praktyka formuvannya fakhovoyi kompetentnosti maybutn'oho vchytelya heohrafiyi u protsesi profesiynoyi pidhotovky [Theory and practice of forming the professional competence of the future teacher of geography in the process of professional training]: avtoref. dys. na zdobuttya nauk. stupenya dokt. ped. nauk: spets. 13.00.04 - teoriya i metodyka profesiynoyi osvity. - Cherkasy:

Cherkas'kyy nats. un-t imeni Bohdana Khmel'nyts'koho, 2011. 43 p.

8. Ukrayinskyi pedahohichnyy slovnyk [Ukrainian Pedagogical Dictionary ] / red. S.U. Honcharenko. Kyiv: Lybid', 1997. 376 p.

9. Fedoryshyn V.I. Teoriya ta metodyka fakhovoyi pidhotovky maybutnikh uchyteliv muzyky na akmeolohichnykh zasadakh. [Theory and methodology of professional training of future music teachers on the basis of acmeology]: avtoref. dys. na zdobuttya nauk. stupenya dokt. ped. nauk: spets. 13.00.02 - Teoriya ta metodyka muzychnoho navchannya. Kyiv: NPU imeni M.P.Dragomanova, 2014. 45 p.

10. Khyzhna O. Filosofs 'ko-synerhetychnyy kontekst pidhotovky maybutn'oho vchytelya do zabezpechennya osnov mystets koyi osvity uchniv pochatkovoyi shkoly [ The philosophical and synergistic context of preparing a future teacher to provide the basics of artistic education for elementary school students]. Psykholoho-pedahohichni problemy sil's 'koyi shkoly. 2010, Issue 34. P. 148-150.

11. Shynkarenko V. Mul'tymediyni tekhnolohiyi yak zasib kompetentnisnoho stanovlennya maybutnikh uchyteliv muzyky [Multimedia technologies as a means of competent formation of future music teachers ]. Humanitarnyy visnyk Derzhavnoho vyshchoho navchal'noho zakladu «Pereyaslav-Khmel'nyts kyy derzhavnyy pedahohichnyy universytet imeni H.S. Skovorody». Pedahohika. Psykholohiya. Filosofiya. - PereyaslavKhmel'nyts'kyy, 2013. Issue. 28 (1). P. 336-340.

12. Chen Kai, Shcholokova Olga. Methodological basis of the future musicianseducators' performance-educational activity. Intellectual Archive. - Toronto : Shiny Word.Corp. (Canada). 2018. (May/June). Vol. 7. No. 3. PP. 5-68.

13. Komarovska Oksana, Huang Hanjie. Readiness for stage partnership in vocalensemble performance as a vector in professional training music teacher. Intellectual Archive. - Toronto: Shiny Word.Corp. (Canada). 2018. (September/October). Vol. 7. No. 5. PP. 66-74. (https://doi.org/10.32370/2018_09_7)

14. Shcholokova O. P. Art and pedagogical designing as a means of improvement of music teacher's professional preparing. Economics, management, law: socio-economical aspects of development: Collection of scientific articles. Volum 2. - Edizioni Magi - Roma, Italy. 2016. P. 265-268 


\section{Translation of the Title, Abstract and References to the Author's Language}

\section{УДК 378.011.3 - 51:78}

Степанов Володимир. Визначення теоретико-методичних засад навчання мультимедійного аранжування майбутніх учителів музики в процесі фахової підготовки.

У статті актуалізовано значення фахової підготовки студентів. Проаналізовано і узагальнено погляди науковців 3 досліджуваної проблеми. Досліджено трактування поняття теоретико-методичних засад та подано власне трактування поняття «теоретикометодичні засади навчання мультимедійного аранжування майбутніх учителів музики», визначено основні складові теоретико-методичних засад навчання мультимедійного аранжування майбутніх учителів музики в процесі фахової підготовки: наукові підходи, принципи, методи. Акцентовано питання інтеграції музично-виконавських дисциплін як оптимальної організації педагогічного процесу на основі міжсуб'єктної взаємодії. Розкрито сутність методики навчання мультимедійного аранжування майбутніх учителів музики; окреслено основні напрямки навчальної роботи, що сприятимуть якості їхньої фахової підготовки у цілому.

Ключові слова: фахова підготовка, теоретико-методичні засади, інтеграція, навчання мультимедійного аранжування, майбутні учителі музики.

\section{Лimepamypa}

1. Великий тлумачний словник сучасної української мови (з дод. і допов.) уклад. i голов. ред. В. Т. Бусел. - Київ: Ірпінь: ВТФ «Перун», 2005. 1728 с.

2. Сременко О. В. Теорія і методика підготовки магістрів музичного мистецтва в педагогічних університетах: автореф. дис. на здобуття наук. ступеня докт. пед. наук: спец. 13.00.02 - Теорія та методика музичного навчання / О.В. Єременко. - Київ: НПУ імені Драгоманова, 2010. 45 с.

3. Ляшко М. Мультимедійні технології як інноваційна складова музичного навчання і виховання. Гуманітарний вісник, 2014. № 33. С. 96-110.

4. Петько Л.В. Виховний потенціал методу ситуаційного аналізу («Case study» method) у формуванні професійно орієнтованого іншомовного навчального середовища в умовах університету. Науковий часопис НПУ імені М.Д. Драгоманова. Серія 17. Теорія і практика навчання та виховання : зб. наук. пр. ; за ред. академіка В.І.Бондаря. Київ: Вид-во НПУ імені М.П.Драгоманова, 2015. Вип. 27. С. 133-140.

5. Петько Л.В. Інформаційно-навчальне середовище як умова формування професійно орієнтованого іншомовного навчального середовища в умовах університету. Інформаційні технології у професійній діяльності: Тр. IX Всеукраїнської наук.-практ. конф., Рівненський державний гуманітарний ун-т, 25 березня 2015 р. Рівне, 2015. C. 89-91.

6. Петько, Л. В. Фільми іноземною мовою у формуванні ПОІНС для студентівбіологів. Критичний підхід у викладанні природничих дисциплін : матеріали Міжнародної науково-методичної конференції, 14 листопада 2018 року / укл. : О. П. Галай [та ін.]. Київ : Вид-во НПУ імені М. П. Драгоманова, 2018. С. 118-124. 
7. Тімець О.В. Теорія і практика формування фахової компетентності майбутнього вчителя географії у процесі професійної підготовки: автореф. дис. на здобуття наук. ступеня доктора пед. наук: 13.00.04 - Теорія і методика професійної освіти / О.В. Тімець - Черкаси: Черкаський національний ун-т імені Богдана Хмельницького. 2011. 43 с.

8. Український педагогічний словник / ред Гончаренко С. У. - Київ: Либідь, 1997. $376 \mathrm{c}$.

9. Федоришин B.I. Теорія та методика фахової підготовки майбутніх учителів музики на акмеологічних засадах: автореф. дис. на здобуття наук. ступеня докт. пед. наук : спец. 13.00.02 - Теорія та методика музичного навчання. Київ: НПУ імені Драгоманова, 2014. 45 с.

10. Хижна О. Філософсько-синергетичний контекст підготовки майбутнього вчителя до забезпечення основ мистецької освіти учнів початкової школи. Психолого-педагогічні проблеми сільської иколи. 2010. Вип. 34. С. 148-150.

11. Шинкаренко В. Мультимедійні технології як засіб компетентнісного становлення майбутніх учителів музики. Гуманітарний вісник Державного вищого навчального закладу «Переяслав-Хмельницький державний педагогічний університет імені Г.С. Сковороди». Педагогіка. Психологія. Філософія. - Переяслав-Хмельницький, 2013. Вип. 28 (1). С. 336-340.

12. Chen Kai, Shcholokova Olga. Methodological basis of the future musicianseducators' performance-educational activity. Intellectual Archive. - Toronto : Shiny Word.Corp. (Canada). 2018. (May/June). Vol. 7. No. 3. PP. 58-68.

13. Komarovska Oksana, Huang Hanjie. Readiness for stage partnership in vocal-ensemble performance as a vector in professional training music teacher. Intellectual Archive. Toronto: Shiny Word.Corp. (Canada). 2018. (September/October). Vol. 7. No. 5. PP. 66-74. (https://doi.org/10.32370/2018_09_7)

14. Shcholokova O.P. Art and pedagogical designing as a means of improvement of music teacher's professional preparing. Economics, management, law: socio-economical aspects of development: Collection of scientific articles. Volum 2. - Edizioni Magi - Roma, Italy. 2016. P. 265-268. 


\title{
To Solve the Problem of Improving Level of Developing a Pedagogical Consciousness in a Future Math Teacher
}

\author{
Bobovsky Roman \\ ORCID ID: https://orcid.org/0000-0003-0172-6404 \\ Lecturer \\ Pereyaslav-Khmelnytsky State Pedagogical University named after \\ Hryhoriy Skovoroda (Ukraine, Pereyaslav-Khmelnytsky)
}

\begin{abstract}
The article deals with the main approaches to the pedagogical conditions definition for forming pedagogical consciousness in the future mathematics teachers. Given some views of the publications, which examined the issue of pedagogical conditions (O. Kachalov, K. Kostyuchenko, V. Manko, L. Maksymchuk, E. Yakovlev, and others) are considered; motivation for educational activities (S. Rubinstein, V. Sukhomlinsky, P. Yakobson, etc.); importance and stimulation of students' research activities (V. Belyaev, S. Goncharenko, Z. Demchenko, V. Kremen, etc.). The conditions such as motivation increase for studying and the interest in pedagogical activities are presents; the formation in the professional training process subjective position of the students is described; an active involvement of the future math teachers in the process of scientific research activities is substantiated. In the case of their systematic, integrated implementation in the process of educationalprofessional training future mathematics teachers they will provide the qualitative increase in the level of stidents' pedagogical consciousness development.
\end{abstract}

Key words: university, students, pedagogical conditions, pedagogical consciousness; motivation; scientific research activitis of students; math teacher training.

Актуальність дослідження. Науковий аналіз проблеми формування педагогічної свідомості майбутніх учителів математики у процесі підготовки в закладах вищої освіти передбачає визначення низки педагогічних умов, що нададуть змогу ефективно побудувати процес формування зазначеного феномену [18, с. 247].

Підготовка майбутніх учителів математики здійснюється в органічній єдності загального, особливого та індивідуального. Загальне полягає у здобутті вищої освіти і $є$ складовою означеної системи; сутність особливого зумовлюється майбутньою педагогічною діяльністю, необхідністю поєднання фахової, педагогічної та науководослідної діяльності. Індивідуальне означає залежність підготовки від індивідуальних особливостей студента, його здібностей, інтересів, рівня знань та ін.

Аналіз результатів, одержаних на констатувальному етапі дослідження, засвідчив перевагу низького та середнього рівня сформованості педагогічної свідомості майбутніх вчителів математики, що підтверджує необхідність обгрунтування 
педагогічних умов формування педагогічної свідомості та їх експериментальної перевірки [17].

Актуальними для дослідження є праці, які розглядали питання про педагогічні

умови (О. Качалов, К. Костюченко, В. Манько, Л. Максимчук, С. Яковлев та ін.); мотивацію навчальної діяльності (С. Рубінштейн, В. Сухомлинський, П. Якобсон, та ін.); важливість та активізацію науково-дослідної діяльності студентів (В. Бєляєв, С. Гончаренко, 3. Демченко, В. Кремень, С. Кушнірук, Л. Петько, Г. Турчинова та ін.).

Виклад основного матеріалу. Питання про педагогічні умови розглядається у роботах значної кількості науковців. Поняття «педагогічні умови» дослідники використовують у значенні компонента освітнього процесу вищої школи, який забезпечує підвищення його результативності [8, с. 25].

У контексті нашого дослідження ми визначаємо педагогічні умови як внутрішні та зовнішні чинники, які сприяють формуванню нових знань, умінь, навичок, компетенцій або компетентностей. При цьому важливим для нас стало твердження Є. Яковлева про те, що об'єкт може успішно функціонувати лише при визначенні певного комплексу умов, оскільки випадкові умови не можуть розв'язати задачу ефективно [16]. Тому ми поставили завдання визначити комплекс організаційнопедагогічних умов, які забезпечать формування у майбутніх учителів математики педагогічної свідомості.

У результаті проведеної аналітичної роботи нами були виділені такі педагогічні умови формування педагогічної свідомості майбутніх учителів математики: підвищення мотивації до навчання та інтересу до педагогічної діяльності у майбутніх учителів математики; формування суб'єктної позиції студентів у процесі професійної підготовки; активне залучення майбутніх учителів математики до науково-дослідницької роботи.

Перейдемо до розкриття сутності згаданих педагогічних умов. Відомо, тобто мотивація в контексті нашого дослідження є стимулюванням бажання до отримання нових знань, умінь та навичок, а також досвіду педагогічної діяльності. П. Якобсон визначає позитивну мотивацію навчання як таку, яка обумовлюється не лише мотивами учбової діяльності, але й життєвими перспективами [15]. Відповідно позитивна мотивація навчання має дуальний характер: індивідуальний та соціальний. 
Зазначимо, що 3 психологічної і педагогічної точки зору важливою $є$ та індивідуальна мотивація, яка грунтується на пізнавальних потребах i iнтересах студентів, на прийнятті ними пізнавальної цінності навчальної діяльності. Л. Божович, А. Маркова, Є. Ільїн та ін. виділяють, перш за все, внутрішню і зовнішню мотивацію. Основу внутрішньої мотивації складають мотиви, безпосередньо пов’язані з навчальною діяльністю (пізнавальні мотиви), а зовнішньої - мотиви, опосередковані зовнішніми щодо навчальної діяльності стимулами (соціальні мотиви) [19; 20; 21].

В. Сухомлинський вказував на зв’язок праці й знань, який полягає у тому, що праця приносить радість, насичує духовне життя тому, що вона- творчість, у ній розкриваються здібності, обдарування, талант - завдяки цьому утверджується почуття людської гідності. Якщо вихователеві вдається досягнути того, що праця вже в шкільні роки стає частиною духовного життя, відбувається винятково важливе явище: трудова творчість пробуджує нові інтелектуальні інтереси, людині хочеться більше знати для того, щоб глибше проникнути в таємниці праці [13, с. 81].

С. Рубінштейн зазначав, що для того, щоб учень по-справжньому включився в роботу, потрібно зробити так, щоб поставлені під час навчальної діяльності завдання він не тільки зрозумів, але й внутрішньо прийняв, тобто щоб вони стали значимими для нього, знайшли відгук і опорну точку в його переживанні. Причому, рівень свідомості, на думку вченого, суттєво визначається тим, наскільки особистісно значимим для учня виявляється те, що об’ єктивно, суспільно значиме [12, с. 500].

Як бачимо, вчені єдині в тому, що мотивація до навчання, інтерес до навчальнопізнавальної діяльності виступають тією рушійною силою, яка обумовлює продуктивність навчального процесу. Окрім того, у сучасному освітньому процесі першочергового значення набуває не так надання предметних знань, обсяг яких постійно росте, а формування особистості як активного діяча, що має відповідну структуру потребнісно-мотиваційної сфери.

Отже, підвищення мотивації до навчання та інтересу до педагогічної діяльності передбачає формування позитивно-ціннісного ставлення та стійкого інтересу до навчальної дисципліни і педагогічної діяльності, до професії вчителя; бажання здійснювати науковий пошук; прагнення до самовизначення, самореалізації, 
самовдосконалення; впевненості у власній психолого-педагогічній готовності до виконання педагогічної діяльності.

М. Левіна, обрунтовуючи сутність діяльнісного підходу як методологічного принципу управління освітнім процесом студентів, який визначає технології навчання, структуру і функціональні взаємини між суб'єктами освітнього процесу, комунікативні діяльнісні зв'язки між викладачем та студентами, синергетичну систему навчання, яка має тенденцію до саморозвитку, стверджує, що концептуальною основою діяльнісного підходу є ідея інтеріоризації взаємодії особистості з освітнім середовищем [7].

Продуктом професійного навчання при цьому виступає формування особистісного i професійного самовизначення. Засобом же досягнення такої мети науковець називає освітні технології дидактичного управління, спрямовані на засвоєння змісту навчальної інформації та організацію нормативних i творчих способів навчального пізнання. Таким чином, діяльнісний підхід до процесу формування педагогічної самосвідомості майбутніх учителів математики реалізується на основі мети, змісту і технологій управління освітньою підготовкою студентів і спрямовується на управління їхньою навчальною діяльністю.

Відповідно, формування педагогічної свідомості майбутніх учителів математики на основі діяльнісного підходу буде успішним за умови дотримання таких принципів: ціннісної значущості підходу до діяльності та іiі результатів 3 позиції користі та значущості; особистісної орієнтації - спрямування діяльності на задоволення особистих цілей; моральної значущості - спрямування діяльності відповідно до мотивів, цінностей та настанов особистості.

Для реалізації означених вимог потрібна така організація навчального процесу, за якої формування знань, вмінь та навичок підпорядковується розвитку складної системи професійної діяльності. Досягнення такого результату вимагає зміни форм та методів організації професійного навчання: замість оволодіння алгоритмами професійної діяльності, які були сталими упродовж багатьох десятиріч, необхідно навчати студентство роботі в швидкозмінних умовах.

У контексті вище сказаного у розрізі проблематики нашого дослідження особливого значення набуває формування суб'єктної позиції студентів у процесі професійної підготовки. А. Осницький, досліджуючи проблеми суб’єктної активності 
вказував, що суб'єктність - це системна якість особистості, що оволодіває різнобічними новими видами і формами діяльності і соціальних відносин, індивідуальним комплексом особистісно-психологічних функцій, котрі визначають і відображають результативність здійснюваної ним діяльності, а також детермінують його сутнісну, інтегральну характеристику - загальну здатність до усвідомленого, самостійного, цілеспрямованого перетворення вихідних знань у соціально значущі якості [10, с. 12]. Суб'єктність проявляється в навчально-пізнавальній діяльності, спілкуванні, самопізнанні і при цьому характеризує досягнутий рівень продуктивності і успішності в здійснюваних видах діяльності, що відображає можливості студента щодо досягнення поставлених цілей i розв'язування конкретних завдань. Відповідно формування педагогічної свідомості вимагає від майбутнього педагога внутрішньої впорядкованості та структурованості смислів, цінностей, здатності до саморегуляції власних дій, ставить особливі вимоги до його професійної позиції і, власне, виявляється через цю позицію.

За необхідне вважаємо зауважимо, що в сучасних умовах розвитку педагогічної науки суб'єктність цілком правомірно можна розглядати як методологічний принцип у педагогічних дослідженнях, присвячених проблемам розвитку активної позиції особистості щодо здійснення нею професійної діяльності та інших форм життєдіяльності. При цьому суб'єкт виступає як активна, діюча, відповідальна за результати своєї праці особистість, здатна до самокритики, самоаналізу, самооцінки.

Крім того, що особливо важливо у контексті проблематики нашого дослідження, суб'єктність визначає особливу форму самоконтролю в різних ситуаціях професійної діяльності. А значить, ми можемо припустити, що вона детермінує і процес формування педагогічної свідомості майбутнього вчителя, який також обумовлюється механізмами самоконтролю та саморегуляції. Саме сформована суб’єктна позиція свідчитиме про результат особистісно-професійного становлення, адже є пов'язаною із самосвідомістю майбутнього фахівця, з усвідомленням ним цілей і завдань професійної діяльності, 3 системою його ціннісних орієнтацій та смислів, з розвиненою здатністю до рефлексії та творчого саморозвитку.

При визначенні наступної педагогічної умови формування педагогічної свідомості майбутніх учителів математики було враховано, що здійснення професійної 
діяльності на рівні, що відповідає сучасним вимогам, під силу педагогу, який постійно вдосконалює свою професійну компетентність, який готовий до здійснення не тільки викладацької, а й науково-дослідної діяльності.

Розв'язання цього завдання можливе, на нашу думку, за умови зміни характеру навчальної діяльності майбутніх учителів математики, за умови переходу зі статусу репродуктивного споживача знань у позицію їх активного творення. Тому важливо, як наголошує академік В. Кремень, «забезпечити високу функціональність людини в умовах, коли зміна ідей, знань і технологій відбувається набагато швидше, ніж зміна покоління людей. Також потрібно віднайти раціональні схеми співвідношення між лавиноподібним розвитком знань, високих технологій і людською здатністю їх творчо засвоїти» [6].

У зв’язку з вищезазначеним, науково-дослідницька діяльність студентів володіє чи не найбільшим потенціалом професійного самовдосконалення особистості майбутнього педагога. Отже, наступною організаційно-педагогічною умовою розвитку педагогічної свідомості майбутніх учителів математики визначено активне залучення до науково-дослідницької роботи.

Як зазначає Ю. Бєляєв, науково-дослідна діяльність студентів - це діяльність, пов’язана з пошуком відповіді на творчу, дослідницьку задачу із заздалегідь невідомим рішенням. Вона включає у себе наступні етапи: постановку проблеми; вивчення теорії, що присвячена означеній проблематиці; добір методик дослідження і практичне оволодіння ними; пошук необхідного матеріалу, його аналіз та узагальнення; власні висновки [1, с. 190].

В «Українському педагогічному словнику» розглядається сутність дослідницького методу, що полягає в залученні учнів до самостійних спостережень, на основі яких установлюються зв'язки предметів і явищ дійсності, пізнаються закономірності, формулюються висновки. С. Гончаренко наголошує, що дослідницька діяльність сприяє вихованню в учнів допитливості, ініціативності, прагнення до самостійного пошуку, розвиває активність їхніх розумових процесів [2].

Аналіз науково-методичної літератури та власний педагогічний досвід дають підстави стверджувати, що науково-дослідницька діяльність студентів є засобом їхньої 
професійної підготовки, адже має всі ознаки навчально-пізнавальної діяльності і водночас творчої, актуалізує творчі можливості особистості $[11 ; 14 ; 22]$.

За необхідне вважаємо зауважити, що, на нашу думку, науково-дослідницька діяльність студентів дає їм можливість відчути себе частиною світової культури (науки), адже за своєю суттю вона $є$ своєрідним інститутом соціалізації молоді і повинна керуватися ії запитами, ціннісними орієнтаціями, потребами творчого розвитку.

Ми розділяємо думку 3. Демченко, який наголошує, що науково-дослідницька діяльність студентів вузу виробляє у них психологічну установку на самостійне потребнісно-мотиваційне поповнення знань і розвиток вміння орієнтуватися в потоці наукової інформації при розв'язанні певних завдань [3, с. 100]. При цьому переконані, що в організації науково-дослідницької діяльності особливу роль відіграє освітнє середовище [22], в якому студенти осягають основи не тільки самої діяльності, але і комунікативної культури, культури міжособистісного спілкування, в якому створюються умови для самоактуалізації і реалізації творчого потенціалу.

Висновки. Таким чином, науково-дослідницька діяльність студентів впливає на побудову їхніх індивідуальних освітніх траєкторій, маршрути подальшого особистісного i професійного самовизначення i самовдосконалення. Через що, реалізація виокремлених організаційно-педагогічних умов у процесі професійної підготовки студентів педагогічного вищого навчального закладу сприятиме, на нашу думку, позитивній динаміці формування педагогічної свідомості майбутніх учителів математики.

\section{References}

1. Bieliaiev Yu.I. Naukovo-doslidna diialnist studentiv u strukturi roboty universytetu [Research activities of students in the structure of the university work] // Pedahohichnyi almanakh. - 2010. - Vol. 6. - P. 188-191.

2. Honcharenko S. Ukrainskyi pedahohichnyi slovnyk [Ukrainian Pedagogical Dictionary]. - Kyiv: Lybid, 1997. - P. 206.

3. Demchenko Z.A. Zhyznennye stratehyy studentov v nauchno- issledovatelskoi deiatelnosty kak pedahohycheskaia problema vysshei professyonalnoi shkoly $v$ ye alternatyvnoe reshenye [Students' life strategies in research as a pedagogical problem of higher vocational school and its alternative solution] // Ystorycheskaia y sotsyalno-obrazovatelnaia mysl. 2012. Vol. 3. P. 98-102.

4. Kachalov A.V. Pedahohycheskye uslovyia formyrovanyia tvorcheskoi samostoiatelnosty studentov pedvuza [Pedagogical conditions of formation of creative independence of students of the pedbuza] // Yzvestyia Uralskoho hosudarstvennoho unyversyteta. - Problemy obrazovanyia, nauky y kultury. 2009. No. 12 (62). P. 212-217. 
5. Kostiuchenko K.Ie. Pedahohichni umovy formuvannia ratsionalno krytychnoho myslennia $u$ maibutnikh uchyteliv $u$ protsesi vyvchennia psykholoho-pedahohichnykh dystsyplin [Pedagogical conditions for the formation of rational-critical thinking in future teachers in the process of studying psychological and pedagogical disciplines]: avtoref. dys. kand. ped. nauk: 13.00.04; Kirovohr. derzh. ped. un-t im. V. Vynnychenka. Kirovohrad, 2011. 20 p.

6. Kremen V.H. Filosofiia liudynotsentryzmu $v$ osvitnomu prostori [Philosophy of human-centeredness in the educational space]. Kyiv: Tov. «Znannia», 2011.530 p.

7. Levyna M.M. Deiatelnostnyi podkhod kak metodolohychekyi pryntsyp upravlenyia obrazovatelnym protsessom studentov [Activity approach as a methodological principle of managing the student's educational process] // Pedahohycheskoe obrazovanye i nauka. 2009. Vol. 2.

8. Maksymchuk L.V. Pedahohichni umovy zastosuvannia interaktyvnykh tekhnolohii u pidhotovtsi maibutnikh ekonomistiv-mizhnarodnykiv [Pedagogical conditions of application of interactive technologies in preparation of future economists-internationalists]. Visnyk Natsionalnoi akademii Derzhavnoi prykordonnoi sluzhby Ukrainy. 2012. Vol. 1. P. 23-29.

9. Manko V.M. Dydaktychni umovy formuvannia u studentiv profesiinopiznavalnoho interesu do spetsialnykh dystsyplin [Didactic conditions of formation of students of professional cognitive interest in special disciplines] // Sotsializatsiia osobystosti: zb. nauk. pr. Natsionalnoho ped. un-tu im. M.P. Drahomanova.

Kyiv: Lohos, 2000. Vol. 2. P. 153-161.

10. Osnytskyi A.K. Problemy issledovanyia subyektnoy aktyvnosty [Problems of study of subject activity]. Voprosy psykholohyy. 1996. Vol. 1. P. 5-19.

11. Pet'ko L.V. Napysannja $i$ zahyst referativ inozemnoju movoju za profesijnym sprjamuvannjam - odyn iz shljahiv pidgotovky studentiv do navchannja u magistraturi [Writing and defense of a report in foreign language (in the professional way) as one of the means of students' preparation for teaching in magistracy] / Naukovyj chasopys Nacional'nogo ped. un-tu imeni M.P. Dragomanova. Serija No 5. Pedagogichni nauky: realii' ta perspektyvy. Vol.35: zbirnyk naukovyh prac'. Kyiv : Vyd-vo NPU imeni M.P.Dragomanova, 2012. P. 132138.

12. Rubynshtein L.S. Osnovy obshchei psykholohyy [Fundamentals of general psychology]. SPb.: Pyter, 2000. P. 720.

13. Sukhomlynskyi V.O. Problemy vykhovannia vsebichno rozvynenoi osobystosti [Problems of education of a fully developed personality]. Vybr. tvory: v 5 t. - Kyiv: Rad. shk., 1976. Vol. 1.654 p.

14. Turchynova H.V. Pidhotovka maibutnikh vchyteliv pryrodnychykh dystsyplin do doslidnytskoi diialnosti u protsesi navchannia inozemnoi movy za fakhom [Future Science teachers training for research activities in the process of foreign language teaching in the professional way]. Topical issues of education: Collective monograph. Pegasus Publishing, Lisbon, Portugal, 2018. 260 p. P. 70-84.

15. Yakobson P.M. Psykholohyia chuvstv y motyvatsyy [Psychology of feelings and motivation]: yzbr. psykhol. tr. - Moskva-Voronezh: Ynt. prakt. psykholohyy; MODEK, 1998. $304 \mathrm{p}$.

16. Yakovlev E.V. Pedahohycheskaia kontseptsyia: metodolohycheskye aspekty postroenyia [Pedagogical Concept: Methodological Aspects of Construction]. Moskva: Humanytar. yzd. tsentr VLADOS, 2006. 239 p. 
17. Bobovsky R.P. Model structural components of pedagogical consciousness formation in future math teacher. Geopolitical processes in the world today: Collection of scientific articles. - «East West» Association for Advanced Studies and Higher Education. Vienna (Austria). 2016. P. 286-289.

18. Bobovsky R.P. Terminological analysis of the concept «pedagogical consciousness» in psychological and pedagogical researches. Science and practice: Collection of scientific articles. - Thorpe Bowker. Melbourne, Australia, 2016. P. 246-267.

19. Kushniruk S. Educational-Methodical Literature as a Resource for the Establishnment and Development of the Conceptual and Terminological System in Ukrainian Didactics (the end of the XVIth century - beginning of the XXIst Century). Intellectual Archive. - Toronto: Shiny Word.Corp. (Canada). 2018. (May/June). Vol. 7. No. 3. PP. 168-181.

20. Kushniruk S.A. Formation of readiness for research activity of students in the process of general-pedagogical preparation. Science and practice: Collection of scientific articles. - Thorpe Bowker. Melbourne, Australia, 2016. - P. 262-267. RSCI: http://elibrary.ru/item.asp?id=28413122

21. Kushniruk S.A. Teaching group activities as an effective form in future competitive teachers training. Actual problems of globalization: Collection of scientific articles. - Midas S.A., Thessaloniki, Greece, 2016. P. 220-223.

URI http://enpuir.npu.edu.ua/handle/123456789/11305,

22. Pet'ko L.V. The formation of professionally oriented foreign language teaching environment for Math students in the conditions of university. Prospects for development of education and science: Collection of scientific articles. - Academic Publishing House of the Agricultural University Plovdiv, Bulgaria, 2016. P. 352-356.

\section{Translation of the Title, Abstract and References to the Author's Language}

\section{УДК 378.011.3-051:51}

\section{Роман Бобовський. До проблеми підвищення рівня розвитку педагогічної свідомості майбутнього вчителя математики}

У статті розглянуто основні підходи до визначення педагогічних умов формування педагогічної свідомості майбутніх вчителів математики. Обгрунтовано умови (підвищення мотивації до навчання та інтересу до педагогічної діяльності; формування суб'єктної позииіі студентів у процесі професійної підготовки; активне залучення майбутніх учителів математики до науково-дослідницької роботи), які, у разі їх систематичного, комплексного впровадження у прочес навчально-професійної підготовки майбутніх учителів математики, забезпечать якісне підвищення рівня розвитку їхньої педагогічної свідомості.

Ключові слова: педагогічні умови; педагогічна свідомість; мотивація; науководослідна робота студентів; підготовка вчителя математики.

\section{Література}

1. Бєляєв Ю.І., Стеценко Н.М. Науково-дослідна діяльність студентів у структурі роботи університету. Педагогічний альманах. 2010. Вип. 6. С. 188-191.

2. Гончаренко С. Український педагогічний словник . Київ: Либідь, 1997. С. 206. 
3. Демченко 3. А. Жизненные стратегии студентов в научно-исследовательской деятельности как педагогическая проблема высшей профессиональной школы и ее альтернативное решение. Историческая и социально-образовательная мысль. 2012. № 3. С. $98-102$.

4. Качалов A.В. Педагогические условия формирования творческой самостоятельности студентов педвуза. Известия Уральского государственного университета. - Проблемы образования, науки и культуры. 2009. № 12 (62). С. 212217.

5. Костюченко К. Є. Педагогічні умови формування раціонально-критичного мислення у майбутніх учителів у процесі вивчення психолого-педагогічних дисциплін: автореф. дис. канд. пед. наук: 13.00 .04 / К.Є. Костюченко; Кіровогр. держ. пед. ун-т ім. В. Винниченка. Кіровоград, 2011.20 с.

6. Кремень В.Г. Філософія людиноцентризму в освітньому просторі. Київ: Тов. «Знання», 2011. С. 530.

7. Левина М.M. Деятельностный подход как методологичекий принцып управления образовательным процессом студентов. Педагогическое образование и наука. 2009. № 2.

8. Максимчук Л.В., Романишина Л.М. Педагогічні умови застосування інтерактивних технологій у підготовці майбутніх економістів-міжнародників. Вісник Національної академії Держсавної прикордонної служби України. 2012. № 1. С. 23-29.

9. Манько В.М. Дидактичні умови формування у студентів професійнопізнавального інтересу до спеціальних дисциплін. Соиіалізаиія особистості: зб. наук. пр. Національного пед. ун-ту ім. М.П. Драгоманова. Київ: Логос, 2000. Вип. 2. C. $153-161$.

10. Осницкий А.К. Проблемы исследования субъектной активности. Bonpocbl психологии. 1996. № 1. С. 5-19.

11. Петько Л.В. Написання і захист рефератів іноземною мовою за професійним спрямуванням - один із шляхів підготовки студентів до навчання у магістратурі / Л.В. Петько // Науковий часопис Національного педагогічного університету імені М.П. Драгоманова. Серія № 5. Педагогічні науки: реалії та перспективи. - Випуск 35 : зб. наук. праць. - Київ: Вид-во НПУ імені М.П. Драгоманова, 2012. С. 132-138.

12. Рубинштейн Л.С. Основы общей психологии. СПб.: Питер, 2000. 720 с.

13. Сухомлинський В.О. Проблеми виховання всебічно розвиненої особистості. Вибр. твори: в 5 т. Київ: Рад. шк., 1976. Т. 1. С. 654.

14. Турчинова Г.В. Підготовка майбутніх вчителів природничих дисциплін до дослідницької діяльності у процесі навчання іноземної мови за фахом / Г.В. Турчинова // Topical issues of education: Collective monograph. - Pegasus Publishing, Lisbon, Portugal, 2018. -260 p. - P. 70-84.

15. Якобсон П.М.Психология чувств и мотивации: избр. психол. тр. МоскваВоронеж: Инт. практ. психологии; МОДЭК, 1998. С. 304.

16. Яковлев Е.В., Яковлева Н.О. Педагогическая концепция: методологические аспекты построения. Москва: Гуманитар. изд. центр ВЛАДОС, 2006. С. 239.

17. Bobovsky R.P. Model structural components of pedagogical consciousness formation in future math teacher. Geopolitical processes in the world today: Collection of scientific articles. - «East West» Association for Advanced Studies and Higher Education. Vienna (Austria). 2016. P. 286-289. 
18. Bobovsky R.P. Terminological analysis of the concept «pedagogical consciousness» in psychological and pedagogical researches. Science and practice: Collection of scientific articles. - Thorpe Bowker. Melbourne, Australia, 2016. P. 246-267.

19. Kushniruk S. Educational-Methodical Literature as a Resource for the Establishnment and Development of the Conceptual and Terminological System in Ukrainian Didactics (the End of the XVIth century - Beginning of the XXIst Century). Intellectual Archive. - Toronto : Shiny Word.Corp. (Canada). 2018. (May/June). Vol. 7. No. 3. PP. 168181.

20. Kushniruk S.A. Formation of readiness for research activity of students in the process of general-pedagogical preparation. Science and practice: Collection of scientific articles. - Thorpe Bowker. Melbourne, Australia, 2016. - P. 262-267. URL: http://elibrary.ru/item.asp?id=28413122

21. Kushniruk S.A. Teaching group activities as an effective form in future competitive teachers training. Actual problems of globalization: Collection of scientific articles. - Midas S.A., Thessaloniki, Greece, 2016. P. 220-223. URI http://enpuir.npu.edu.ua/handle/123456789/11305 ,

22. Pet'ko L.V. The formation of professionally oriented foreign language teaching environment for Math students in the conditions of university. Prospects for development of education and science: Collection of scientific articles. - Academic Publishing House of the Agricultural University Plovdiv, Bulgaria, 2016. P. 352-356. 


\title{
Polyartistic Potential of Music Theory Subjects in Training Music Teachers
}

\author{
Komarovska Oksana \\ ORCID https://orcid.org/0000-0002-3679-9673 \\ Doctor of Sciences in Pedagogy \\ Head of Aesthetic and Art Education Laboratory of the Institute of \\ Problems on Education of the National Academy of Educational Sciences of \\ Ukraine
}

Xia Gaoyang

ORCID https://orcid.org/0000-0002-2871-9952

Postgraduate student (China)

Dragomanov National Pedagogical University (Ukraine, Kyiv)

\begin{abstract}
The article is devoted to the theoretical analysis of polyartistic content of musicology subjects in the professional training of future music teacher. The relation between musical-historical and musical-theoretical (in the narrow sense) disciplines has been revealed. The author determines that courses of music history and analysis of musical works are primarily polyartistic. The course History of music is determined as an integral part of the subjects of solfeggio, harmony, polyphony etc. The top of hierarchy of musicology disciplines is an analysis of musical works. Musical analysis is, essentially, the attempt to bridge the gap between students' intuitions about music and their conscious knowledge of it. In analysing works that students feel to be intrinsically worthwhile they are trying to correlate their subjective responses with observable properties in the music.

The initial methodological viewpoints of implementation of the polyartistic potential of musicaltheoretical training music teacher have been considered. The purpose of the article is to reveal the pedagogical potential of polyartistic activities in socio-communicative development of future Music teachers which is interpreted in the context of globalization, cultural development of a modern society. The necessity of the developmental potential implementation of polyartistic phenomena in order to develop of the holistic person is proved. It is defined the essence of concepts "polyartistic" and "multicultural", which are interpreted in the context of globalization, cultural development of a modern society.

Key words: future Music teacher, polyartistic training, musical-theoretical disciplines, history of music, analysis of musical works.

Актуальність проблеми. Питання поліхудожньої підготовки педагога-музиканта та учнів у системі загальної освіти інтенсивно розробляється впродовж останніх десятиліть (Л. Масол, Т. Рейзекінд, Л. Савенкова, Г. Шевченко, Б. Юсов). Упровадження
\end{abstract}


інтегративної мистецької освіти в Україні, де навчається автор статті (Л. Аристова, О. Боблієнко, Л. Масол), потребує готовності вчителя музики до оволодіння методиками, технологіями поліхудожнього навчання та власної поліхудожньої освіченості. Для китайської освіти взаємодія мистецтв, що базується на поліхудожності, має ментальне підгрунтя, а єдність мистецтв закладена у національні традиції.

Музично-теоретична підготовка вчителя музики постійно перебуває в полі уваги (М. Калашник, Ван Яюєци, К. Васильковська, С. Коробецька, Ю. Локарєва,

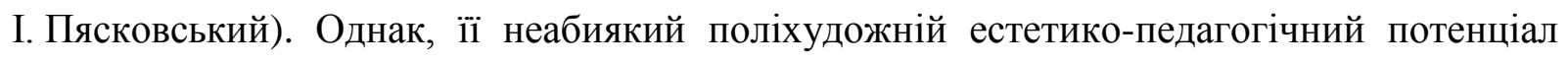
поки що обгрунтований недостатньо.

Мета статті - розкрити поліхудожній потенціал музично-теоретичних дисциплін (МТД) як чинника фахової підготовки студентів-музикантів педагогічних університетів.

Виклад основного матеріалу. У процесі фахової підготовки студенти-музиканти педагогічних університетів опановують комплекс музикознавчих дисциплін:музичноісторичні (історія музики (охоплює розділи вітчизняної і зарубіжної музики минулого і сучасності, різних стильових епох, національних культур), музичне народознавство); власне музично-теоретичні (сольфеджіо, елементарна теорія музики, гармонія, поліфонія, інструментознавство, аранжування, аналіз музичних творів). У поліхудожній підготовці стрижневу роль відіграє історія музики (IM), що інтегрує досвід 3 елементарної теорії музики, сольфеджіо, гармонії, поліфонії: через вивчення теорії в широкому розумінні уможливлюється занурення у стильові особливості музичної мови, а музичні стилі як квінтесенція втілення музичної образності пізнаються в історичному ракурсі. Суто теоретичні дисципліни закладають основи музично-теоретичної грамотності, формують уміння цілісного аналізу твору як художнього феномену. Вивчення історії музики акумулюється під час вивчення курсу аналізу музичних творів $(A M T)$, який є верхівкою піраміди музикознавчих дисциплін і для якого фундаментом слугує саме курс IM як інтегральний. Відтак, у системі музично-теоретичної підготовки IM та АМТ є дисциплінами первинно полі художніми.

Отже, МТД розуміємо як ієрархію дисциплін, через взаємодію яких найбільш цілеспрямовано розкривається поліхудожній потенціал. Первинну основу музичнотеоретичної підготовки у векторі поліхудожності складають дисципліни, що безпосередньо спрямовані на розвиток у студентів музичних здібностей; далі ті, що 
домінантні у формуванні музичного мислення, дослідницької здатності, чуття стилю, художнього смаку, навичок сприймання, фантазії, уяви (тобто IM та AMT).

Проектуючи вивчення МТД у поліхудожній контекст, розуміємо, що він охоплює різновекторне синтезування засобів різних видів мистецтва, спрямованих на розуміння музичної образності, оскілки стрижнем підготовки для майбутнього вчителя музики постає багатогранне опанування саме музичного твору. Зазначимо, що єдиної класифікації мистецтв, в естетико-філософській думці поки немає. Тому спираємось на праці філософів [2; 6], мистецтвознавців [1; 5], педагогів мистецтва $[7 ; 8 ; 6 ; 10 ; 14]$, які розкривають важливу для реалізації полі художнього підходу природу синтезу мистецтв.

Маємо справу переважно з музикоцентричною інтеграцією або синтезом мистецтв [12; 13], центром тяжіння в якому є музичний складник. Відтак, відзначимо опорні позиції виявлення та реалізації поліхудожнього потенціалу IM.

По-перше, опанування майбутніми вчителями музики змісту IM спрямоване на художнє пізнання творів у культурологічному та історико-хронологічному ракурсі. Кожне музичне явище розглядається в історико-культурному контексті певної епохи та певної країни (регіону світу) і має вивчатися поряд 3 творами інших мистецтв i встановленням смислових, образних, стильових зв язків з ними.

По-друге, твори, які вивчаються IM, належать різним жанрам. Але в контексті поліхудожньої підготовки логічно виокремити так звані синтетичні. Йдеться про твори музичного театру - опери, балети, оперети, мюзикли. Традиційно в IМ увага звертається на особливості їхнього музичного складника (музична драматургія, образність, вокальний та оркестровий компоненти), тобто твір вивчається не як багатошаровий текст для сценічного втілення, а як суто музичний. На жаль, цілісний сценічний образ, аналіз можливих сценічних інтерпретацій залишається поза увагою.

По-третє, для поліхудожньої підготовки важливе значення має вивчення творів 3 програмовою основою (літературною, живописною, історичною, філософською), яка неминуче викликає міжмистецькі асоціації, активізує синестезійні відчуття з живописом, графікою, скульптурою, архітектурою, сюжетами літератури, історичними постатями $\mathrm{i}$ подіями тощо.

По-четверте, враховуємо, що значна частина світового музичного доробку створена для драматичного театру, екранних мистецтв або ж використовується 
режисерами в театрі або на екрані, супроводжує різноманітні життєві події, створюючи смисловий підтекст. Сам факт такого використання музичних творів викликає необхідність осмислення їх в іншій художньо-образній ситуації і в зіставленні 3 виразними засобами інших мистецтв.

Нарешті, n`ята позиція, - твори, які залишаються в суто музичних образних та мовленнєвих межах, але для поглиблення емоційного осягнення яких можливо залучати інші мистецтва, наприклад, для зіставлення вирішення певного сюжету засобами різних мистецтв, у процесі виконання творчих завдань зі створення літературно-музичних композицій, сценаріїв, які «озвучуються» музикою і супроводжуються зоровим рядом тощо.

Поліхудожній потенцііал АMT збігається із зазначеним щодо IM, за винятком того, що не є обов’язковою історико-хронологічна послідовність. Натомість у поясненні закономірностей музичної розвитку, опанування предмету спираємось на досвід, здобутий майбутнім учителем музики з IM.

Вивчення IM та АМТ передбачає й оволодіння ключовими поняттями, що є спільними для всіх мистецтв (художній образ, стиль, жанр, форма, композиція, динаміка, ритм тощо). Так, до «синтезуючих» механізмів відносять конкретно-предметну образність; музичний образ; музично-пластичний і зображально-пластичний жест; зображувальну деталь у зіставленні з динамікою руху образу; специфічні мовні та надмовні засоби; конкретизацію музичної образності та комп’ютерної віртуальності тощо [9].

Обидва курси мають двоєдине підгрунтя: 1) опора на внутрішні, міжмистецькі зв’язки; 2) «вихід» у суміжні дисципліни, опанування яких сприяє заглибленню і в музичний твір, і в твори інших мистецтв та у мистецьку палітру як цілісність (зв'язки 3 естетикою, мистецтвознавством, культурологією, психологією музики і музичної творчості та психологією інших видів художньої творчості); це вимагає вивчення мови інших мистецтв, що спрямовується і на аналіз творів, і на виконавську, педагогічну, просвітницьку, лекторську діяльність, на науковий пошук у сфері мистецтва. Повноцінна реалізація цього передбачає теоретичне, емпіричне і практично-творче оволодіння способами взаємодії засобів мистецтв для розуміння художнього образу [3; 4; 11$]$. 
Важливою для поліхудожньої підготовки э увідомлення спорідненості термінологічного тезаурусу. Наприклад, Л. Масол зазначає, що художній образ твору і поняття, які є основною категорією педагогіки мистецтв, взаємодоповнюють один одного: поняття мовби «просвітлюють логікою» образні уявлення, емоційні відчуття, інтуїтивні прозріння. Поняття з різних сфер можуть збігатися повністю чи частково, не збігатися взагалі, мати різний масштаб спільної царини перетину [4; 5]; в музиці $\epsilon$ специфічно-музичні та неспещифічно-музичні засоби, запозичені від інших мистецтв. Наприклад, ритм, гармонійність, пропорційність, рівновага, симетрія та асиметрія, динаміка та статика, контраст і нюанс, фактура та інші в одних мистецтва набувають статусу точного визначення, а в інших використовуються як образна метафора. До основних категорій з образотворчого мистецтва належать форма, колір, композиція, рисунок. Для музики - інтонація. Додамо: очевидними є паралелі між «фонізмом» у музиці і «колоритом» у живопису; лінією у графіці, мелодією, малюнком танцю; орнаментом у декоративному мистецтві і танці, орнаментальністю в музиці тощо.

Таким чином, поліхудожній потенціал МТД полягає в комплексному пізнанні музичних творів через розкриття: 1) універсальної здатності музики «притягувати», синтезувати інші мистецтва в новий художній результат - безпосередньо в різних формах синтезу, й опосередковано - через різного типу програмність; 2) унікальної (завдяки інтонаційній природі) здатності створювати емоційний контекст i підтекст для глибинного освоєння мови інших мистецтв і навпаки - розкривати свої підтексти через залучення впливу засобів інших мистецтв та їхнього цілісного осмислення; 3) об’ єктивної здатності бути драматургічною основою в синтетичних видах і жанрах, які поза музичним складником взагалі втрачають доцільність існування, що потребує від реципієнтів і творців такого синтезу особливої поліхудожньої чутливості і знань 3 музикознавства, мистецтвознавства та психології художнього сприймання різних мистецтв та їхнього синтезу; 4) притаманної лише музичним творам спроможності сповіщати елементи руху, інтонаційного розгортання іншим видам мистецтва в художньо-образній цілісності.

Найбільш дієвими і є такі первинно поліхудожні дисципліни, як IM та AMT, які спираються на здобутки майбутніх учителів музики під час вивчення інших, вузько теоретичних монохудожніх курсів. 
Висновки. Поліхудожня підготовка вчителя музики як реалізація відповідного потенціалу МТД не є самоціллю. Її орієнтиром постає формування фахівця з цілісною художньою свідомістю, здатного збагачувати в духовному напрямі власне життя i застосовувати досвід у роботі з майбутніми учнями та іншими людьми. Така діяльність $€$ одночасно умовою, метою і самим процесом духовної актуалізації та розвитку особистості [6, с. 78]. Таке розуміння поліхудожньої підготовки актуалізує вектор подальших досліджень - єдність особистісних надбань і готовність передавати досвід учням.

\section{References}

1. Asafiev B.V. Muzykalnaia forma kak protsess [Musical form as a process]. Leningrad: Musica, 1971. $376 \mathrm{p}$.

2. Kahan M. S. Morfologiia iskusstva [Morphology of art]. Leningrad: Iskusstvo, 1972. $440 \mathrm{p}$.

3. Komarovska O.A. Mystetska osvita: peredchuttia zmin ta hotovnist uchytelia do nykh [Artistic education: a premonition of change and a teacher's readiness for them.]. Mystetstvo ta osvita. 2017. No 3. P. 10-15.

4. Komarovska O.A. Khudozhno-inonatsiinyi prostir zhyttia yak dzherelo tsinnostei pidrostaiuchoi osobystosti [Artistic-intonational space of life as a source of values of personality's developing: psychological and pedagogical aspects]. Topical issues of education: Collective monograph. - Pegasus Publishing, Lisbon, Portugal, 2018. - P. 260-280.

5. Metodyka navchannia mystetstva u pochatkovii shkoli [Methodology of teaching Art in elementary school]: posib. dlia vchyteliv / L. Masol [ta in.]. Kharkiv: Vesta, vyd-vo «Ranok», 2006. $-256 \mathrm{p}$.

6. Oleksiuk O., Tkach M. Pedahohika dukhovnoho potentsialu osobystosti: sfera muzychnoho mystetstva [Pedagogy of spiritual potential of personality: sphere of musical art]: navch. posibnyk. Kyiv: Znannia Ukrainy, 2004. 264 p.

7. Pet'ko L. V. Robota nad pisneju v kursi anglijs'koi' movy jak odyn iz zasobiv profesijnoi' pidgotovky studentiv gumanitarnyh special'nostej VNZ [The song in English course as a means of training humanities majors university students']. Inozemni movy. 2011. No. 1. P. 44-48.

8. Pet'ko L. V. Formuvannya profesiyno orientovanogo inshomovnogo navchalnogo seredovishcha $v$ umovah universitetu dlya studentiv spetsialnosti «Muzichne mistetstvo» (na prikladi virsha Meri Hovitt «Pavuk i Muha») [Formation of professionally oriented foreign language teaching environment in the terms of university for students of Music Art specialty (on illustration of a poem «The Spider and the Fly» by Mary Howitt)]. Naukovi zapiski Berdyanskogo derzh. ped. un-tu: zb. nauk. pr. Issue 1. Berdyansk : FO-P Tkachuk O.V., 2016. P. 184-190.

9. Reizenkind T. Y. Suchasni naukovi metody piznannia u polikhudozhnii pidhotovtsi maibutnoho vchytelia muzyky [Modern scientific methods of knowledge in multi artistic training 
future Music teacher]. Naukovyi chasopys NPU im. M. P. Drahomanova. Seriia 14: Teoriia i metodyka mystetskoi osvity. 2010. Issue 9. P. 24-27.

10. Komarovska O. Art Pedagogics in the Context of Civilizational Change: On the Problems of Teacher Training / Professional Artistic Education and Culture within Modern Global Transformations; ed. by O.Oleksiuk. Cambridge: Cambridge Scholars Publishing. 2018. PP. 79-85.

11. Komarovska Oksana, Huang Hanjie. Readiness for Stage Partnership in VocalEnsemble Performance as a Vector in Professional Training Music Teacher. Intellectual Archive. Toronto: Shiny Word.Corp. (Canada). 2018. (September/October). Vol. 7. No. 5. PP. 66-74. (https://doi.org/10.32370/2018_09_7)

12. Pet'ko Lyudmila, Tkachova Christina. Ballet on Ice. Nauka i Studia ; redactor Fr.Antoni. Filologiczne nauki. Psychologia i Socjologia. Przemys`1 : Nauka i Studia, 2014. No 7 (117). P. 111-115.

13. Pet'ko Lyudmila, Akulenko Svetlana. Shakespeare. «Romeo and Juliet». Ballet Art. Nauka i Studia ; redactor Fr.Antoni. - Filologiczne nauki. Psychologia i Socjologia. Przemys`l : Nauka i Studia, 2014. No 7 (117). P. 89-95.

14. Shcholokova O.P. Art and pedagogical designing as a means of improvement of music teacher's professional preparing. Economics, management, law: socio-economical aspects of development: Collection of scientific articles. Vol. 2. Edizioni Magi, Roma, Italy. 2016. P. 265-268.

\section{Translation of the Title, Abstract and References to the Author's Language}

УДК [378: 78.08]: 781.2

Комаровська О., Ся Гаоян. Педагогічний потенціал музично-теоретичних дисциплін у поліхудожній підготовці учителів музики.

У статті подано теоретичний аналіз поліхудожнього змісту музикознавчих предметів у фаховій підготовці майбутнього вчителя музики. Розкрито взаємозв'язок музично-історичних та музично-теоретичних (у вузькому сенсі) дисциплін. Визначено, що курси історії музики та аналізу музичних творів $є$ первинно поліхудожніми. Курс історії музики позиціонується авторами як інтегральний стосовно предметів сольфеджіо, гармонія, поліфонія тощо. Показано, що верхівкою в ієрархії музикознавчих дисциплін у контексті поліхудожності є аналіз музичних творів. Розглянуто вихідні методичні позиції реалізації поліхудожнього потенціалу музично-теоретичної підготовки вчителя музики.

Ключові слова: майбутній учитель музики, полі художня підготовка, музичнотеоретичні дисципліни, історія музики, аналіз музичних творів.

\section{Лimepamypa}

1. Асафьев Б. В. Музыкальная форма как процесс. - Л. : Музыка, 1971. 376 с.

2. Каган М. С. Морфология искусства. Ленинград : Искусство, 1972. 440 с.

3. Комаровська О.А. Мистецька освіта: передчуття змін та готовність учителя до них. Мистецттво та освіта. 2017. № 3. С. 10-15. 
4. Комаровська О.А. Художньо-інонаційний простір життя як джерело цінностей підростаючої особистості. Topical issues of education: Collective monograph. Pegasus Publishing, Lisbon, Portugal, 2018. P. 260-280.

5. Методика навчання мистецтва у початковій школі : посіб. для вчителів /Л. Масол [та ін.]. Харків: Веста, вид-во «Ранок», 2006. 256 с.

6. Олексюк О., Ткач М. Педагогіка духовного потенціалу особистості: сфера музичного мистецтва. Київ: Знання, 2004. 264 с.

7. Петько Л. В. Робота над піснею в курсі англійської мови як один із засобів професійної підготовки студентів гуманітарних спеціальностей ВНЗ. Іноземні мови. 2011. № 1. С. 44-48.

8. Петько Л. В. Формування професійно орієнтованого іншомовного навчального середовища в умовах університету для студентів спеціальності «Музичне мистецтво» (на прикладі вірша Мері Ховітт «Павук і Муха»). Наукові записки Бердянського державного педагогічного університету. Педагогічні науки: зб. наук. пр. Вип. 1. Бердянськ: ФО-П Ткачук O.B., 2016. C. 184-190. URI http://enpuir.npu.edu.ua/handle/123456789/10075

9. Рейзенкінд Т. Й. Сучасні наукові методи пізнання у поліхудожній підготовці майбутнього вчителя музики. Науковий часопис НПУ імені М. П. Драгоманова. Серія 14 : Теорія і методика мистецької освіти. 2010. Вип. 9. С. 24-27.

10. Komarovska O. Art Pedagogics in the Context of Civilizational Change: On the Problems of Teacher Training / Professional Artistic Education and Culture within Modern Global Transformations; ed. by O.Oleksiuk. Cambridge: Cambridge Scholars Publishing. 2018. PP. 79-85.

11. Komarovska Oksana, Huang Hanjie. Readiness for Stage Partnership in VocalEnsemble Performance as a Vector in Professional Training Music Teacher. Intellectual Archive. Toronto: Shiny Word.Corp. (Canada). 2018. (September/October). Vol. 7. No. 5. PP. 66-74. (https://doi.org/10.32370/2018_09_7)

12. Pet'ko Lyudmila, Tkachova Christina. Ballet on Ice // Nauka i Studia ; redactor Fr.Antoni. Filologiczne nauki. Psychologia i Socjologia. Przemys`1 : Nauka i Studia, 2014. No 7 (117). P. 111-115.

13. Pet'ko Lyudmila, Akulenko Svetlana. Shakespeare. «Romeo and Juliet». Ballet Art // Nauka i Studia ; redactor Fr.Antoni. Filologiczne nauki. Psychologia i Socjologia. Przemys`1 : Nauka i Studia, 2014. No 7 (117). P. 89-95.

14. Shcholokova O. P. Art and pedagogical designing as a means of improvement of music teacher's professional preparing. Economics, management, law: socio-economical aspects of development: Collection of scientific articles. Vol. 2. Edizioni Magi, Roma, Italy. 2016. P. 265-268. 


\title{
Ethno-Artistic Competence of Student Youth: Diagnostic Procedure
}

\author{
Qiao Zhi \\ ORCID https://orcid.org/0000-0002-0532-3111 \\ Postgraduate student (China) \\ Dragomanov National Pedagogical University (Ukraine, Kyiv)
}

\begin{abstract}
The article deals with the author's definition of personality's ethno-artistic competence as an integral personal formation in the context of ethnic intercultural dialogue. Ethno-artistic competence is considered as a result of students' immersing into a variety of folklore - music, poetry, dance, theater, arts and crafts, which is acquired during musical training. The author considers the ethnoartistic competence to be an integral part of person that unites the aspects of ethnic preparation based on native folklore and polyethnic aspects. Polyethnicity predicts the result of interethnic artistic and creative tolerance and respect for human attitudes toward folklore of other ethnic cultures. The author presents the results of an empirical study on the diagnostics of ethno-artistic competence of students. The information obtained serves as the guidelines to improve ethno-artistic training of students.

The structure of ethno-artistic competence has been distinguished; the content of the components (ethnocognitive, motivational-activity, reflexive, communicative and poly-ethnic) has been considered; the criteria for its diagnostics (emotional-value, ethno-cognitive, motivational-activity, reflexive, communicative and polyethnic) have been substantiated; the characteristics of the studied quality have been specified. The interrelation between content of the components during diagnostics is taken into account.
\end{abstract}

Key words: ethno-artistic competence, students, diagnosis, criteria and indicators.

Актуальність проблеми. Нині світ спостерігає за тим, як у глобалізаційних процесах посилюються тенденції зближення культур і водночас прагнення етносів збереження ідентичності. Стосовно мистецької освіти ці проблеми відображено в документах ЮНЕСКО (Конвенція ЮНЕСКО «Про охорону та заохочення розмаїття форм культурного самовираження»), а також в законодавстві різних країн, зокрема Китаю (Державна національна програма «Китай - XXI століття», Стратегія розвитку освіти в Китаї в XX1 ст. та ін.), України (Національна стратегія розвитку освіти в Україні на період до 2021 року, документи «Нової української школи», Концепція художньо-естетичного виховання учнів у загальноосвітніх навчальних закладах України).

Питання етнокультурного розвитку як важливі для міжкультурного 
діалогу, співіснування в мультикультурному світі, привертають увагу в теоретичному $\mathrm{i}$ прикладному напрямі (Вей Лімін, В. Дикало, Інь Хань, М. Качур, І. Кон, С. Лур’є, Ю. Руденко, Л. Петько, Сунь Гоцян, Сююй Цзяюй, Хай Лінь, О. Хижна, І. Ціко, Лібінь, Чень Ін, Г. Яківчук). Суттєвими для розуміння етнопсихологічні й фольклористичні праці (Ю. Бромлей, А. Іваницький, ЛуЛу, С. Лурье). «Мистецтво у складні для будь якого етносу часи стає силою, що спонукає людину визначатися в етнічному плані» [16, c. 16]. Загострення в юнацькому віці проблеми міжособистісного діалогу, вагомим чинником здатності до якого є фольклор різних національних культур і видів мистецтва, актуалізує методичні аспекти формування етномистецької компетентності.

Мета статті - визначити критерії та показники, за якими доцільно ідентифікувати сформованість етномистецької компетентності молоді.

Виклад основного матеріалу. Спираючись на аналіз джерел [1; 6; 9; 17], етномистецьку компетентність тлумачимо як інтегральний особистісний феномен, що характеризує освоєння людиною мистецьких традицій власного етносу, виявляється в мотивації до етномистецького пізнання у комплексі знань, умінь опанування традицій; в дієво-ціннісному ставленні до фольклору рідного етносу (емоційністю переживання, рефлексії та самооцінки); презентується у спроможності відтворення й примноження в комунікації з представниками свого етносу, в пошануванні і толерантності інших етнокультур [14; 15]. Отже, цілісну структуру етномистецької компетентності складають етнокогнітивний (конкретизуєтся у площині різновидів мистецького фольклору), аксіологічний, діяльнісно-творчий, мотиваційний, рефлексивний, комунікативний, та власне естетичний компоненти (умовно, його зміст пронизує решту компонентів) [14].

Критеріями є: емоційно-ціннісний (відповідає одночасно аксіологічному та естетичному компонентам); етнокогнітивний; мотиваційно-діяльнісний; рефлексивний; комунікативно-поліетнічний. Зміст кожного з критеріїв може виявляти себе через спільні характеристики і показники.

Емоційно-иіннісний критерій зосереджений на особливостях емоційно-ціннісного ставлення до народного мистецтва рідного краю, що виявляється в та мірі інтересу до мистецького явища, навичках сприймання творів у єдності емоційності сприймання та аналізу-інтерпретації творів, коли відбувається осмислення сприйнятого; на з'ясуванні 
того, чи увійшло сприйняте до особистісних цінностей (бажанні опановувати нові для себе художні цінності, популяризувати їх). Цей критерій є мірилом емоційної сфери поряд зі здатністю рефлексії: ціннісне ставлення неможливе поза переживанням сприйнятих творів і здатністю виокремлювати естетичний смисл творів та зіставити його з реаліями: відбувається ідентифікація особистості з культурою етносу, а також відбувається вирізнення свого від «іншого» [2; 3]. Етнічна мистецька традиція реалізує свій педагогічний потенціал, коли створює у свідомості особистості глибокий емоційний образ етносу, формуючи у людини ціннісну позицію щодо себе $[4 ; 5 ; 17 ; 20 ;$ $21 ; 22]$.

Етнокогнітивний критерій зосереджений на діагностуванні знань вітчизняного фольклоруу єдності драматургічного, музичного, танцювального, декоративноприкладного, поетичного, атрибутивного складників, пам’яток культури, уявлень спадщину відомих митців, зокрема тих, чия творчість спирається на народні традиції; а також враховує аналогічну обізнаність у народному мистецтві інших етносів. Оцінювання сформованості етномистецької компетентності за етнокогнітивним критерієм розвиває художню ерудованість, визначає, якому мистецтву особистість надає перевагу та наскільки i щодо яких мистецтв учень володіє мистецьким тезаурусом, наскільки уміє проводити паралелі між художніми образами та життям.

Усвідомлення пізнаного стимулює подальше поглиблення знань; формується рефлексія як здатність свідомого ставлення до фольклору рідного та інших етносів.

Мотиваційно-діяльнісний критерій виявляє готовність до практичного освоєння та поширення рідного фольклорного матеріалу та інших культур. Фіксується художньопрактичний досвід ознайомлення 3 фольклорними цінностями, виконавські уміння, вмотивованість до пізнання, інтерпретації, вивчення й виконання творів, поширення й уведення пізнаного у власне дозвілля. Усі ці прояви неможливі поза дією емоційної сфери і ціннісними орієнтаціями, а також поза уміннями аналізу та навичками виконавської діяльності та прагненнями творчого самовираження в ній. Оцінюючи сформованість етномистецької компетентності учнів за цим критерієм, передбачаємо: саме в діяльності виявляються характеристики, які відображені в етнокогнітивному й емоційно-ціннісному критеріях, а в саму діяльність учні включаються за умови розвиненості мотивації. 
Рефлексивний критерій охоплює як осмислення художньої значущості творів, що пізнаються у сприйманні та в практичній діяльності, так і усвідомлення власної причетності до рідного етносу й невід’ємності від національної мистецької спадщини, усвідомлення місця мистецтва в цілому або певних його видів та жанрів у своєму житті. Важливим в оцінюванні етномистецької компетентності є усвідомлення можливостей мистецтва відображати внутрішній світ іншої людини і цілого етносу та усвідомлювати себе у зв'язках з іншими на основі сприймання конкретних творів. Розвиток рефлексії як усвідомлення і «творіння» самого себе, пов’язаний з діалогічним процесом переживання художніх образів у процесі сприймання та інтерпретації, осмислення своїх вражень тощо [11; 13; 18; 19;]. Під діалогом слід розуміти, на наш погляд, діалог з образністю творів рідного мистецтва i 3 образністю, жанровими, мовними особливостями мистецьких явищ інших етнічних культур. Отже, оцінювання етномистецької компетентності за рефлексивним критерієм також пов'язано зі змістом решти критеріїв.

Комунікативно-поліетнічний критерій враховує, наскільки усвідомлюється значення мистецтва як засобу комунікації людей і культур; охоплює, толерантність ставлення до народного мистецтва інших етносів, що акумулює емоційність їх сприймання й розуміння цінності у світовій культурі, обізнаність 3 іншоетнічною традиційною культурою й мистецькими явищами, вмотивованість до пізнання, інтерпретації, практичного освоєння, осмислення «інакшості» своєї культури у порівнянні 3 іншими i навпаки. Застосування цього критерію передбачає, що поліетнічність постає у двох вимірах: як толерантність ставлення і спілкування 3 мистецтвом етносів у межах рідної культури з усвідомленням ролі в цілісності культури та ii взаємозбагаченні, а також толерантність ставлення і спілкування 3 мистецтвом інших етнічних культур Світу.

Відповідно до змісту критеріїв до кожного з них визначаємо показники.

Показниками емоційно-ц̧іннісного критерію є:емоційність сприймання і виконання творів рідного мистецтва та інших етнічних культур;здатність інтонаційної ідентифікації мистецького матеріалу різної етнічної належності на елементарночуттєвому рівні (серед вивчених творів);інтерес до рідного фольклору та прихильне ціннісно-смислове ставлення до іншоетнічного фольклору різних видів і жанрів. 
Показниками етнокогнітивного критерію є: знання рідних мистецьких традицій; обізнаність у мистецьких етнічних традиціях інших культур; уміння здійснювати аналіз-інтерпретацію творів.

Показниками мотиваційно-діяльнісного критерію є: потреба практично-творчого опанування мистецьких творів рідної культури в навчально-виховній діяльності та у дозвіллі (ознайомлення, сприймання, вивчення, виконання, поширення); прагнення самовираження і самовдосконалення через практичну діяльність у процесі пізнання рідного фольклору; вмотивованість до ознайомлення з фольклором інших культур 3 прихильним ставленням до них.

Показниками рефлексивного критерію є: усвідомлення причетності до рідної культури через освоєні мистецькі явища;усвідомлення відмінності і спільності мистецьких традицій рідної та інших етнічних культур;прагнення осмислювати власну творчість.

Показниками комунікативно-поліетнічного критерію $\epsilon$ : готовність до ознайомлення 3 мистецтвом інших етнічних культур та толерантне ставлення до іншоетнічних відмінностей у мистецькому фольклорі; прагнення зіставляти мистецькі твори рідної культури та інших етнічних культур (сюжети, жанри, засоби виразності); знання правил толерантного спілкування й уміння застосовувати їх у спільному пізнанні мистецтва.

Висновки. Застосування запропонованого діагностувального інструментарію дозволить вчасно виявляти проблеми і недоліки у процесі пізнання мистецтва рідного етносу та інших етносів, які складають єдину культурну картину світу, окреслить перспективні методики такого пізнання..

\section{References}

1. Dykalo V.I. Muzychn ekraieznavstvo Rivnenshchyny yak navchalnyikurs: do postanovky problem [Music regional studies of Rivne as a training course: before the problem]. Nova pedahohichna dumka. 2016. No 32 (86). P. 124-128.

2. Komarovska O.A. Mystetski dosiahnennia uchniv: shcho i yak otsiniuiemo? [The pupils' artistic achievements: What do we appreciate?].Mystetstvo ta osvita. 2018. No 4. P.2-7

3. Komarovska O.A. Artistic-intonational space of life as a source of values of personality's developing: psychological and pedagogical aspects. Topical issues of education: Collective monograph. Pegasus Publishing, Lisbon, Portugal, 2018. P. 260-280. 
4. Komarovska O. A. Khudozhnii obraz tvoru yak proiav obdarovanosti myttsia [Artistic image of a work as display of gifted artist]. Mystetstvo ta osvita. 2009. No 4. P. 4-6.

5. Komarovska O. A. Shkola estetychnoho vykhovannia u systemi mystetskoi osvity [School of aesthetic education in the system of artistic education]. Psykholoho-pedahohichni problemy silskoi shkoly: zb. nauk. prats Umanskoho derzh. ped. un-tu im. Pavla Tychyny. Uman: PP Zhovtyi O. O., 2012. Issue 40. P. 312-319.

6. Kontseptsiia khudozhno-estetychnoho vykhovannia uchniv $u$ zahalnoosvitnikh navchalnykh zakladakh ta Kompleksna prohrama khudozhno-estetychnoho vykhovannia $u$ zahalnoosvitnikh ta pozashkilnykh navchalnykh zakladakh [Concept of artistic and aesthetic education of students in general educational institutions and Integrated program of artistic and aesthetic education in general and out-of-school educational institutions]. MON Ukrainy. Nakaz No 151/11 vid 25.02.2004. URL: http://zakon.rada.gov.ua/rada/show/ru/v1_11290-04.

7. Mystetstvo. Navchalna prohrama dlia zahalnoosvitnikh navchalnykh zakladiv. 5-9 klasy [Art.Educational program for general educational institutions. 5-9 grades.]. URL: https://ru.osvita.ua/school/program/program-5-9/56132/

\section{Mystetstvo. Prohrama dlia zahalnoosvitnik hnavchalnykh zakladiv 10-11 klasy [Art. Program for general education institutions 10-11 grades]. URL: https://mon.gov.ua/ua/osvita/zagalna-serednya-osvita/navchalni-programi/navchalni-programi- dlya-10-11-klasiv}

9. Osypets R. O. Formuvannia natsionalnoi samosvidomosti maibutnikh uchyteliv zasobamy ukrainskoi narodnopisennoi kultury [Formation of national self-consciousness of future teachers by means of Ukrainian folk song culture]. Kyiv: Mahister-S, 1999. 207 p.

10. Pankiv L. I. Formuvannia mystetskykh oriientatsii starshoklasnyka yak vektor dukhovnoho rozvytku osobystosti [Formation of artistic orientations of a senior pupil as a vector of spiritual development of personality]. Mystetstvo ta osvita. 2016. No 1. P. 16-19.

11. Pet'ko L.V. Shljahy formuvannja inshomovnoi' sociokul'turnoi' kompetencii' studentiv mystec'kyh special'nostej VNZ u procesi fahovoi' pidgotovky [The Ways of Formation of Foreign Language Socio-Cultural Competence of Students of Music-Pedagogical Specialties in Higher School in the Process of Professional Teaching]/ Problemy pidgotovky suchasnogo vchytelja: $\mathrm{zb}$. nauk. pr. Umans'kogo derzhavnogo ped. un-tu imeni Pavla Tychyny. Uman: PP Zhovtyj O.O., 2012. Vol. 6. Part 3. P. 57-62.

12. Pet'ko L.V., Danilko E.V. Vzaimodejstvie iskusstv na urokah muzyki v srednej obshheobrazovatel'noj shkole [Cooperation of arts on the Music lessons in secondary school]: Tez. dokl. uchastnikov mezhrespublikanskogo seminara-soveshhanija. Voroshilovgrad. 1990. P. 43-47.

13. Rudnytska O. P. Muzyka i kultura osobystosti: problem suchasnoi pedahohichnoi osvity [Music and culture of personality: problems of modern pedagogical education]. Kyiv, 1998. $248 \mathrm{p}$.

14. Qiao Zhi. Sutnist etnokulturnoi kompetentnosti: teoretychnyi aspect [The essence of ethno-cultural competence: Theoretical aspect]. Teoretyko-metodychni problem vykhovannia ditei ta uchnivskoi molodi. Vol. 20, Issue. 2. Kyiv, 2016. P. 297-306. 
15. Qiao Zhi, Komarovska O. A. Kytaiski narodni tradytsii v muzychnomu navchanni ukrainskykh shkoliariv [Chinese folk traditions in musical education of Ukrainian schoolchildren]. Mystetstvo ta osvita. 2017. No 4. P. 6-10.

16. Shulha R. P. Mistse etnichnoho faktoru $v$ protsesi funktsionuvannia mystetstva [Place of ethnic factor in the process of functioning of art]. Teoretychni problemy khudozhnoi kultury: zb. nauk. st. Pereiaslav-Khmelnytskyi, 1995. Issue. 1. P. 14-18

17. Yakivchuk H. V. Vykhovannia tvorchoi osobystosti maibutnoho vchytelia muzyky u protsesi vyvchennia ukrainsko homuzychnoho folklore [Education of creative personality of future music teacher in the process of studying Ukrainian folk music]. Avtoreferat of dissertation. Kyiv, 2009. 20 p.

18. Komarovska Oksana, Huang Hanjie. Readiness for stage partnership in vocal-ensemble performance as a vector in professional training music teacher. Intellectual Archive. - Toronto: Shiny Word.Corp. (Canada). 2018. (September/October). Vol. 7. No. 5. PP. 66-74. (https://doi.org/10.32370/2018_09_7)

19. Pet'ko Lyudmila. About socio-culturological content in teaching subjects / Lyudmila Pet'ko // Development strategy of science and education: Collection of scientific articles. - Fidelite editions, Namur, Belgique, 2017. - P. 316-319.

URI http://enpuir.npu.edu.ua/handle/123456789/13881

20. Pet'ko L.V. Formation of professionally oriented foreign language teaching environment in the conditions of university for students of specialties 023 «Fine Arts» and 022 «Design». Economics, management, law: realities and perspectives: Collection of scientific articles. Psychology. Pedagogy and Education. - Les Editions L'Originale, Paris, France. 2016. P. 466-470.

21. Pet'ko Lyudmila. Sociocultural comprehension of ethnoconcept "RED RUE" // Science and society: Collection of scientific articles. - Edizioni Magi, Roma, Italia, 2017. P. 460-466. URI http://enpuir.npu.edu.ua/handle/123456789/18483

22. Shcholokova O.P. Art and pedagogical designing as a means of improvement ofmusic teacher's professional preparing. Economics, management, law: socio-economical aspects of development: Collection of scientific articles. Volum 2. Edizioni Magi, Roma, Italy. 2016. P. 265-268.

\section{Translation of the Title, Abstract and References to the Author's Language}

УДК [37.01: 373-379.8] : 398

Цяо Чжи. Етномистецька компетентність учнівської молоді: процедура діагностування.

У статті подано авторське тлумачення етнокультурної компетентності особистості як інтегрального особистісного утворення в контексті полі етнічного міжкультурного діалогу. Етномистецька компетентність подається як результат занурення учнів у різновиди фольклору - музичного, поетичного, танцювального, театрального, декоративно-прикладного мистецтва, який опановується під час музичного навчання. Виокремлено структуру етномистецької компетентності, розглянуто зміст компонентів та обгрунтовано критерії іiі діагностування (емоційно- 
ціннісний, етнокогнітивний, мотиваційно-діяльнісний, рефлексивний, комунікативнополіетнічний); конкретизовано показникові характеристики досліджуваної якості.

Ключові слова: етномистецька компетентність, учнівська молодь, діагностування, критерії та показники.

\section{Лimepamypa}

1. Дикало В. I. Музичне краєзнавство Рівненщини як навчальний курс: до постановки проблеми. Нова педагогічна думка. 2016. 32 (86). С. 124-128.

2. Комаровська О.А. Мистецькі досягнення учнів: що і як оцінюємо?. Мистейтво та освіта. 2018. № 4. С. 2-7.

3. Комаровська О.А. Художньо-інтонаційний простір життя як джерело цінностей підростаючої особистості. Topical issues of education: Collective monograph. Pegasus Publishing, Lisbon, Portugal, 2018. P. 260-280.

4. Комаровська О.А. Художній образ твору як прояв обдарованості митця. Мистейтво та освіта. 2009. № 4. С. 4-6.

5. Комаровська О. А. Школа естетичного виховання у системі мистецької освіти. Психолого- педагогічні проблеми сільської школи : зб. наук. праць Уманського держ. пед. ун-ту ім. Павла Тичини / [ред. кол.: Побірченко Н. С. (гол. ред.) та ін.]. - Умань : ПП Жовтий О. О., 2012. Вип. 40. С. 312-319.

6. Концепція художньо-естетичного виховання учнів у загальноосвітніх навчальних закладах та Комплексна програма художньо-естетичного виховання у загальноосвітніх та позашкільних навчальних закладах / Наказ МОН України від 25.02.2004. № 151/11 URL: http://zakon.rada.gov.ua/rada/show/ru/v1_11290-04.

7. Мистецтво. Навчальна програма для загальноосвітніх навчальних закладів. 5-9 класи. URL: https://ru.osvita.ua/school/program/program-5-9/56132/

8. Мистецтво. Програма для загальноосвітніх навчальних закладів 10-11 класи. URL: https://mon.gov.ua/ua/osvita/zagalna-serednya-osvita/navchalni-programi/navchalniprogrami-dlya-10-11-klasiv

9. Осипець Р. О. Формування національної самосвідомості майбутніх учителів засобами української народнопісенної культури. Київ: Магістер-S, 1999. 207 с.

10. Паньків Л. І. Формування мистецьких орієнтацій старшокласника як вектор духовного розвитку особистості. Мистецтво та освіта : науково-методичний журнал. 2016. № 1 . С. 16-19.

11. Петько Л. В. Шляхи формування іншомовної соціокультурної компетенції студентів мистецьких спеціальностей ВНЗ у процесі фахової підготовки // Проблеми підготовки сучасного вчителя: зб. наук. пр. Уманського державного пед. ун-ту імені Павла Тичини / [ред. кол.: Побірченко Н.С. (гол.ред) та ін.]. - Умань: ПП Жовтий О.О., 2012. Вип. 6. Ч. 3. С. 57-62.

12. Петько Л. В., Данилко Е. В. Взаимодействие искусств на уроках музыки в средней общеобразовательной школе // Взаимодействие искусств в духовном развитии школьников: Тр. докл. участников межреспубликанского семинара-совещания 17-19 
апреля 1990 г. Ворошиловград: Редакционно-издательский отдел облполиграфиздата. 1990. C. 43-47.

13. Рудницька О. П. Музика і культура особистості: проблеми сучасної педагогічної освіти. Київ, 1998. 248 с.

14. Цяо Чжи. Сутність етнокультурної компетентності: теоретичний аспект // Теоретико-методичні проблеми виховання дітей та учнівської молоді: зб. наук. пр. Київ, 2016. Вип. 20. Кн. 2. С. 297-306.

15. Цяо Чжи, Комаровська О.А. Китайські народні традиції в музичному навчанні українських школярів. Мистецтвво та освіта. 2017. № 4. С. 6-10.

16. Шульга Р. П. Місце етнічного фактору в процесі функціонування мистецтва // Теоретичні проблеми художньої культури: зб. наук. ст. Переяслав-Хмельницький, 1995. Вип. 1. С. 14-18.

17. Яківчук Г. В. Виховання творчої особистості майбутнього вчителя музики у процесі вивчення українського музичного фольклору : автореф. дис. ... канд. пед. наук: 13.00.07. Київ, 2009. 20 с.

18. Komarovska Oksana, Huang Hanjie. Readiness for stage partnership in vocal-ensemble performance as a vector in professional training music teacher. Intellectual Archive. - Toronto: Shiny Word.Corp. (Canada). 2018. (September/October). Vol. 7. No. 5. PP. 66-74. (https://doi.org/10.32370/2018_09_7)

19. Pet'ko Lyudmila. About socio-culturological content in teaching subjects. Development strategy of science and education: Collection of scientific articles. - Fidelite editions, Namur, Belgique, 2017. - P.316-319. URI

http://enpuir.npu.edu.ua/handle/123456789/13881

20. Pet'ko L V. Formation of professionally oriented foreign language teaching environment in the conditions of university for students of specialties 023 «Fine Arts» and 022 «Design». Economics, management, law: realities and perspectives: Collection of scientific articles. Psychology. Pedagogy and Education. - Les Editions L'Originale, Paris, France. 2016. P. 466-470.

21. Pet'ko Lyudmila. Sociocultural comprehension of ethnoconcept "RED RUE" // Science and society: Collection of scientific articles. - Edizioni Magi, Roma, Italia, 2017. - P. 460-466. URI http://enpuir.npu.edu.ua/handle/123456789/18483

22. Shcholokova O.P. Art and pedagogical designing as a means of improvement ofmusic teacher's professional preparing / O.P. Shcholokova // Economics, management, law: socio-economical aspects of development: Collection of scientific articles. Volum 2. Edizioni Magi - Roma, Italy. - 2016. - P. 265-268. 


\title{
The Technology for Forming Professional Reflection in Future Social Work Educators in a Higher Educational Institution
}

\author{
Chernukha Nadezhda \\ ORCID https://orcid.org/0000-0003-2184-7406/print. \\ Doctor of Pedagogical sciences, Professor \\ Vasylieva-Khalatnykova Maryna \\ ORCID https://orcid.org/0000-0002-8488-4602/print. \\ Lecturer \\ Tokaruk Lyudmyla \\ ORCID https://orcid.org/0000-0002-7330-406X/print. \\ Ph.D., Associate Professor \\ Department of social rehabilitation and social pedagogy \\ Taras Shevchenko National University (Kyiv, Ukraine)
}

\begin{abstract}
The article analyzes the technology for forming professional reflection in future social work educators in a higher education institution. Given technology is described as scientific and theoretical basis for the optimal implementation of the tasks of professional training. This technology is considered as a set of regular, functionally related components which presents an integral system. Selected components in technology are divided into some blocks (goal-oriented, functional, informative, organizational, productive). This components provide an opportunity to represent more clearly the purposeful process of forming professional reflection in future social work educators in the higher education institution. They highlighted how social work educators' future work in agencies help them to operationalize social work values and ethics, develop an awareness of themselves as social workers, and enhanced their confidence.

Key words: technology, professional reflection, social teacher, institution of higher education, pedagogical conditions.

Актуальність. Для успішної реалізації завдань у системі професійної освіти доцільно мати чітку науково-теоретичну основу для обгрунтування та розробки технології формування професійної рефлексії майбутніх соціальних педагогів у закладі вищої школи.

Сучасні зміни в українському соціумі обумовлюють необхідність створення ефективної системи підготовки фахівців для соціальної та соціальнопедагогічної роботи. Сьогодення, виклики часу потребують фахівця, здатного організовувати, сприяти створенню соціальних умов для реалізації цілей різних категорій клієнтів у професійній і життєвій самореалізації [1;2; 7; 9; 10; 11; 12].
\end{abstract}


Метою статті є розкриття особливостей впровадження технології формування професійної рефлексії майбутніх соціальних педагогів у закладі вищої школи.

Технологія формування професійної рефлексії майбутніх соціальних педагогів у закладі вищої школи інтегрує критичне, альтернативне мислення майбутніх соціальних педагогів, їх дослідницьку, професійну позицію, що спирається на фундамент концептуальних та соціально-значущих критеріїв аналізу та оцінки професійної діяльності.

Варто зазначити, що професійна діяльність майбутніх соціальних педагогів нерозривно пов'язана зі спілкуванням. Завдяки йому майбутні соціальні педагоги вчаться самовизначенню, виробленню професійної позиції, засвоєнню нового знання. Наприклад, С. В. Кондратьєва та В. О. Кривошеєв [3, с. 184-186] досліджували професійну рефлексію у процесі педагогічного спілкування, розрізняючи два типи рефлексії - комунікативну та особистісну.

Викладення основного матеріалу. Рефлексивна підготовка майбутніх соціальних педагогів у закладі вищої школи припускала таку їі організацію, що сприяла формуванню високого (творчого) та середнього (достатнього) рівнів знань, умінь та навичок в галузі професійної рефлексії. ÏÏ загальними компонентами $\epsilon$ : система знань щодо професійної рефлексії майбутніх соціальних педагогів, що розвиває рефлексивне мислення та система умінь та навичок, що формується рефлексивною діяльністю. Означена система є практико-орієнтованою, тобто, містить результати досліджень щодо проблеми рефлексії та професійної рефлексії в межах філософської, психологічної та педагогічної наукової літератури; професійної рефлексії соціальних педагогів в межах діяльності та майбутніх соціальних педагогів в межах професійної підготовки у закладі вищої школи (теорія професійної рефлексії); практичний матеріал (завдання, вправи, прийоми), що формують професійну рефлексію майбутніх соціальних педагогів у закладі вищої школи (методика професійної рефлексіі).

Процес формування професійної рефлексії майбутніх соціальних педагогів 
у закладі вищої школи є частиною освітнього процесу, як підсистема він має якості цілого й тому має свою мету, компоненти, певну структуру, механізм функціонування, кінцевий результат, зв’язок з цілісним педагогічним процесом.

Для забезпечення сталого формування професійної рефлексії майбутніх соціальних педагогів доцільно використовувати технологізацію, оскільки пряме експериментування небезпечне для майбутньої діяльності фахівців соціальної сфери.

Проаналізуємо розроблену нами технологію формування професійної рефлексії майбутніх соціальних педагогів у закладі вищої школи більш докладно (рис. 1).

Під технологією формування професійної рефлексії майбутніх соціальних педагогів у закладі вищої школи ми розуміємо цілісний педагогічний процес, у якому сукупність форм, методів, засобів навчання спрямована на набуття майбутніми соціальними педагогами певних знань, умінь та навичок, а також на розвиток особистостей студентів як майбутніх практиків професійної діяльності із відповідними компетентностями та компетенціями.

Зазначимо, що технологія має особливості структури (елементи та етапи процесу формування), послідовний зв'язок цих елементів та особливості конструювання змісту формування професійної рефлексії майбутніх соціальних педагогів у закладі вищої школи. Розроблена технологія розглядається як сукупність закономірних, функціонально пов'язаних компонентів, що становлять певну цілісну систему. Виділення компонентів у технології дозволило розбити іiі на блоки (цільовиц̆, функціональний, змістовий, організаційний, результативний), які забезпечили можливість більш чітко уявити цілеспрямований процес формування професійної рефлексії майбутніх соціальних педагогів у закладі вищої освіти.

Цільовий блок. Метою освітнього процесу є забезпечення досягнення середнього (достатнього) та високого (творчого) рівнів сформованості професійної рефлексії майбутніх соціальних педагогів. Іїі реалізація і виконання полягають у таких завданнях: засвоїти теорію, ознайомити 3 основними 


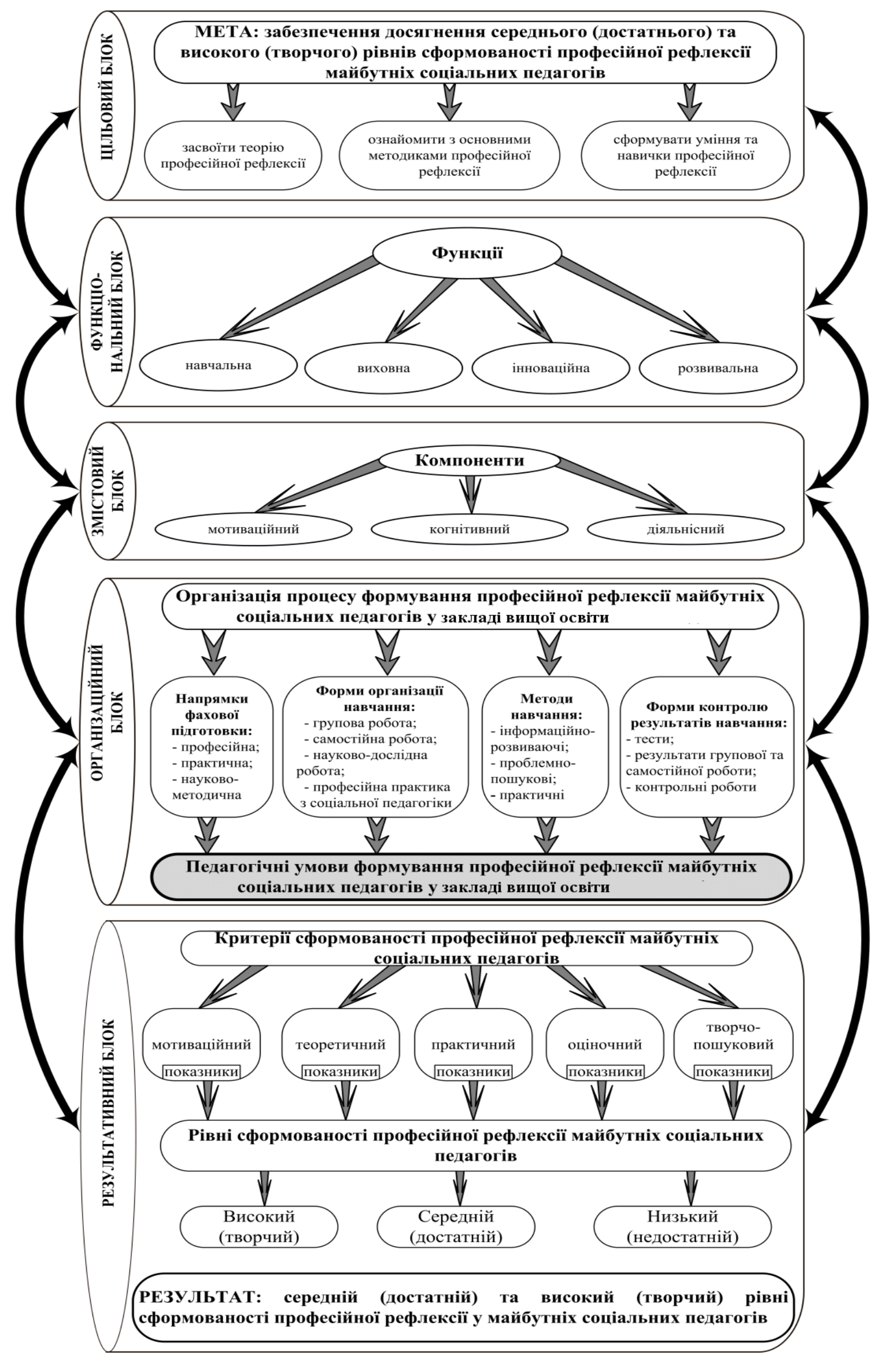

Рис. 1. Технологія формування професійної рефлексії майбутніх соціальних педагогів у закладі вищої освіти. 
методиками, сформувати уміння та навички професійної рефлексії у майбутніх соціальних педагогів.

Функціональний блок дозволяє виділити функції процесу формування професійної рефлексії майбутніх соціальних педагогів у закладі вищої школи: навчальну - формування у майбутніх соціальних педагогів системи знань про професійну рефлексію та можливості iї використання у практичній діяльності; виховну формування професійних установок та принципів, стандартів професійної поведінки; інноваційну - формування у свідомості майбутніх соціальних педагогів здатності до вирішення професійних завдань, сприяння розвитку таких якостей, як професійна мобільність і можливість адаптації до нових умов, що змінюються професійною діяльністю; розвивальна - сприяння формуванню майбутніх соціальних педагогів як особистостей та підготовка їх до самостійної професійної діяльності, самореалізації. Ефективне функціонування розробленої технології не можливе без формування у майбутніх соціальних педагогів знань, умінь і навичок професійної рефлексії; формування професійної спрямованості особистостей майбутніх соціальних педагогів; використання спецкурсу, побудованого на основі виявлення i встановлення міждисциплінарних зв’язків між загальноосвітніми та спеціальними навчальними дисциплінами.

Змістовий блок. У відповідності до мети та завдань, процес формування професійної рефлексії майбутніх соціальних педагогів у закладі вищої освіти розглядається як специфічний вид освітньої діяльності, спрямований на майбутніх соціальних педагогів 3 метою розвитку та формування їх особистостей як професіоналів. Дану діяльність визначають мотиваційний, когнітивний та діяльнісний компоненти.

Мотиващійний компонент покликаний формувати у майбутніх соціальних педагогів мотивації до професійної діяльності, розуміння сенсу цієї діяльності і свого місця в ній. Когнітивний компонент спрямований на формування у майбутніх соціальних педагогів професійних цінностей та ідеалів. Діяльнісний компонент вимагає у майбутніх соціальних педагогів конкретної дії, вчинку, поведінкового акту, застосування соціальної і професійної норми, вироблення професійної звички. 
Наступний блок технології - організаційний, в якому ми виділяємо процесуальний аспект формування професійної рефлексії майбутніх соціальних педагогів у закладі вищої освіти.

Формування професійної рефлексії майбутніх соціальних педагогів у закладі вищої освіти здійснюється під впливом усіх компонентів освітнього процесу як єдиного цілого. Цей блок представлений: напрямками фахової підготовки (професійна, практична, науково-методична); формами організащії навчання (групова робота, самостійна робота, науково-дослідна робота, професійна практика 3 соціальної педагогіки); методами навчання (інформаційно-розвиваючі, проблемно-пошукові, практичні); формами контролю результатів навчання (тести, результати групової та самостійної роботи, контрольні роботи).

Впровадження технології формування професійної рефлексії майбутніх соціальних педагогів у закладі вищої освіти неможливо без врахування педагогічних умов піi реалізації. За суттю вони є своєрідним «стрижнем», що дозволяє їй функціонувати та бути дієвою. До педагогічних умов дієвості технології формування професійної рефлексії майбутніх соціальних педагогів у закладі вищої освіти ми відносимо: базові (системний, безперервний, контрольований вплив на процес формування професійної рефлексії майбутніх соціальних педагогів у закладі вищої освіти; навчальні умови закладу вищої освіти (технологічні, психологічні, навчальнометодичні, побутові, часові), процесуальні (орієнтація рефлексивної підготовки майбутніх соціальних педагогів у закладі вищої освіти на специфіку професійної діяльності, постійний контакт 3 організаціями, які надають послуги 3 соціальної педагогіки, створення рефлексивного середовища та активізація суб'єкт-суб'єктних взаємовідносин між науково-педагогічними працівниками та постійний контакт 3 організаціями, які надають послуги з соціальної педагогіки, створення рефлексивного середовища та активізація суб'єкт-суб'єктних взаємовідносин між науковопедагогічними працівниками та майбутніми соціальними педагогами у закладі вищої освіти, вдосконалення робочих навчальних програм 3 дисциплін професійного спрямування майбутніх соціальних педагогів у закладі вищої освіти) та формувальні (розуміння майбутніми соціальними педагогами актуальності та важливості формування професійної рефлексії у закладі вищої освіти, усвідомлений вибір майбутніми соціальними педагогами спеціальності «Соціальна педагогіка», 
формування стійкої мотивації щодо актуальності та важливості формування професійної рефлексії у закладі вищої освіти, навчально-методичне забезпечення цього процесу).

Напрямки фахової підготовки, форми організації навчання, методи навчання та форми контролю результатів навчання підпорядковуються педагогічним умовам формування професійної рефлексії майбутніх соціальних педагогів у закладі вищої освіти.

Результативний блок. Представлений критеріями та показниками рівнів сформованості професійної рефлексії майбутніх соціальних педагогів. Результатом ефективності технології формування професійної рефлексії майбутніх соціальних педагогів у закладі вищої школи є досягнення середнього (достатнього) та високого (творчого) рівнів сформованості професійної рефлексії у майбутніх соціальних педагогів.

Структурні блоки запропонованої технології $є$ взаємозв'язаними, тому досягнення мети неможливо без їх врахування. Відтак, ми пропонуємо здійснювати формування професійної рефлексії майбутніх соціальних педагогів у закладі вищої освіти на основі технології, що складається собою певну цілісну систему і дозволяє забезпечити можливість більш чіткого уявлення цілеспрямованого процесу формування професійної рефлексії майбутніх соціальних педагогів.

Впровадження технології формування професійної рефлексії майбутніх соціальних педагогів у закладі вищої освіти неможливо без врахування педагогічних умов іiі реалізації. Не дивлячись на те, що вони виступали у складі організаційного блоку обгрунтованої та розробленої технології, за суттю вони $є$ своєрідним «стрижнем», що дозволив їй функціонувати та бути дієвою. Для того, щоб впровадження технології було ефективним, необхідним є більш чітке їх розуміння та врахування при організації процесу формування професійної рефлексії у закладі вищої освіти.

Висновки. Формування професійної рефлексії майбутніх соціальних педагогів у закладі вищої освіти є успішним при наявності відповідних педагогічних умов. При чому, необхідно виявити, проаналізувати та узагальнити у системному вигляді ті педагогічні умови, які ефективно впливають на процес та професійне становлення майбутніх соціальних педагогів. Чим краще визначені та обгрунтовані педагогічні 
умови, тим більш ефективні результати досягаються. Принципові особливості означеного процесу проявляються у неможливості примусити майбутніх соціальних педагогів опанувати професійною рефлексією, способами та прийомами рефлексивної діяльності, до пошуку відповідної інформації щодо рефлексії взагалі та професійної рефлексії, зокрема. Прийнятними залишаються опосередковано-стимулюючі засоби впливу на майбутніх соціальних педагогів, що припускають активізацію їх як суб’ єктів особистісного та професійного становлення.

Таким чином, від того, у яких педагогічних умовах буде здійснюватися професійна підготовка майбутніх соціальних педагогів у закладі вищої освіти, залежить ефективність технології формування професійної рефлексії.

\section{References}

1. Velinskij M. Ya., Obrozcov P. I., Uman A. I. Tekhnologii professional'noorientirovannogo obucheniya $v$ vysshej shkole [Technology of professionally oriented education in higher education]: ucheb. posobie. Moskva: Ped. o-vo Rossii, 2004. 189 p.

2. Ziaziun I. Profesiina osvita : pedahohika i psykholohiia [Professional education: pedagogy and psychology] / za red. I. Ziaziuna, N. Nychkalo. Kyiv: Vyscha shkola, 2003. $568 \mathrm{p}$.

3. Kondrat'eva S. V., Krivosheev V. A. Pedagogicheskaya refleksiya nachinayushchih uchitelej [Pedagogical reflection of novice teachers] // Tezisy dokl. k VII syezdu obshchestva psihologov SSSR. Moskva: 1989. P. 184-186.

4. Monahov V. M. Tekhnologicheskie osnovy proektirovaniya i konstruirovaniya pedagogicheskogo processa [Theoretical foundations of the design and construction of the pedagogical process]. Moskva: 1996. $225 \mathrm{p}$.

5. Osvitni tekhnologhiji [Educational technologies]: navch.-metod. posibnyk / O. M. Pekhota ta in. Kyiv: A. S. K., 2002. 255 p.

6. Pet'ko L. V. Filosofs'ko-lingvistychni idei' rozuminnja mizhljuds'koi' komunikacii' $u$ social'nomu seredovyshi [Philosophical and linguistic ideas of interpersonality communication in professional sphere]. Naukovi zapysky. Ostrog: Vyd-vo «Ostroz'ka akademija», 2015. Serija «Filologichna». Vol. 53. PP. 353-356.

7. Petko L.V. Vyklyky XXI stolittia dlia osvitnoho prostoru Ukrainy. Naukovi pratsi ChNU: nauk. zhurnal [The challenges of educational space in the 21 - $^{\text {st }}$ century]. Mykolaiv: Vvo ChNU imeni Petra Mohyly, 2017. Vol. 303. Issue 291. P. 10-14.

8. Pet'ko L. V. Stymuljuvannja gotovnosti majbutnih social'nyh pedagogiv do vyhovnoi' roboty u procesi vyvchennja inozemnoi' movy u VNZ (na prykladi kinofil'mu "Zvuky muzyky» ("The Sound of Music»), SShA, rezh. Uajz, 1965 r.) [Stimulation of readiness of the future social teachers in a higher education institution for educational work in the process of foreign language learning (on the example of the movie «The Sound of Music», USA, Director R. Wise, 1965)]. Aktual'ni problemy navchannja ta vyhovannja 
ljudej v integrovanomu seredovyshhi: zb. nauk. prac' No 9 (11). Kyiv: Universytet «Ukrai'na». 2012. PP. 84-95.

9. Plakhotnik O. V., Vasyljjeva-Khalatnykova M. O. Profesijna refleksija $u$ dijaljnosti socialjnogho pedaghogha [The professional reflexion in the work of social teacher]: navchaljno-metodychnyj pos. Kyiv, 2013. 248 p.

10. Chernukha N.M. Formyrovanye sotsyalnoi aktyvnosty studentov v sovremennom intehratsyonnom obrazovatelnom prostranstve [Formation social activity of students in studentov in modern educational space]. Osvitnia polityka derzhavy. Kyiv, 2014. P.137-140

11. Chernukha N.M., Aslanov H. Sotsialni komunikatsii v interkulturnomu prostori: vidpovid na vyklyky sohodennia [Social communications in intercultural space: response to challenges]. Innovative processes in education: Collective monograph. - AMEET Sp. z o.o., Lodz, Poland, 2017.

12. Kulyk Olena. Reflection as a component to professional becoming tomorrow's specialist in the higher education system. Topical questions of contemporary science: Collection of scientific articles. Aspekt Publishing of Budget Printing Center, Taunton, MA 02780, United States of America, 2017. P. 441-447.

13. Shkolna Maria. Pedagogical conditions for upbringing social maturity of students' agricultural colleges. Intellectual Archive. Toronto: Shiny Word.Corp. (Canada). 2017. September/October. Vol. 6. No. 5. PP. 79-85.

\section{Translation of the Title, Abstract and References to the Author's Language}

\section{УДК 378.012.11.234}

Чернуха Н. М., Васильєва-Халатникова М. О., Токарук Л. С. Технологія формування професійної рефлексії майбутніх соціальних педагогів у закладі вищої школи.

У статті подано технологію формування професійної рефлексії майбутніх соціальних педагогів у закладі вищої школи. Розроблена технологія розглядається як сукупність закономірних, функціонально пов'язаних компонентів, що становлять певну цілісну систему. Виділення компонентів у технології дозволило розбити ії на блоки (цільовий, функціональний, змістовий, організаційний, результативний), які забезпечують можливість більш чітко уявляти цілеспрямований процес формування професійної рефлексії майбутніх соціальних педагогів у закладі вищої школи. Формування професійної рефлексії майбутніх соціальних педагогів у закладі вищої школи буде успішним при наявності відповідних педагогічних умов. Запропоновано педагогічні умови, які ефективно впливають на процес та професійне становлення майбутніх соціальних педагогів.

Ключові слова: технологія, професійна рефлексія, соціальний педагог, заклад вищої школи, педагогічні умови.

\section{תimepamypa}

1. Виленский М. Я., Образцов П. И., Уман А. И. Технологии профессиональноориентированного обучения в высшей школе : уч. - Москва: Педагогическое общество России, 2005. - 192 с.

2. Зязюн І. А. Педагогіка добра: ідеї і реалії: наук.-метод. посібник. - Київ: МАУП, 2003. - 312 с. 
3. Кондратьєва С. В., Кривошеєв В. О. Педагогічна рефлексія майбутніх // Тези доп. до VII с’їзду спільноти психологів. - Москва: 1989. - С. 184-186.

4. Монахов В. М. Технологічні основи проектування та конструювання педагогічного процесу. - Москва: 1996. - 225 с.

5. Освітні технології: навч.-метод. посібник / О. М. Пехота [та ін.]. - Київ: А. С. K., 2002. - 255 c.

6. Петько Л. В. Філософсько-лінгвістичні ідеї розуміння міжлюдської комунікації у соціальному середовищі. Наукові записки Національного університету «Острозька академія». Серія «Філологічна» : зб. наук. праць / укл. І.В.Ковальчук, Л.М.Коцюк, С.М.Новоселецька. Острог : Вид-во Національного ун-ту «Острозька академія», 2015. Вип. 53. С. 309-312.

7. Петько Л. В. Виклики ХХІ століття для освітнього простору України. Наукові nраці [Чорноморського держ. ун-ту імені Петра Могили комплексу "КиєвоМогилянська академія"]. Серія : Педагогіка : наук. журн. / Чорном. держ. ун-т імені Петра Могили; ред. кол. : О. П. Мещанінов (голова) [та ін.]. Миколаїв : Вид-во ЧНУ імені Петра Могили, 2017. Т. 303. Вип. 291. С. 10-14.

8. Петько Л.В. Стимулювання готовності майбутніх соціальних педагогів до виховної роботи у процесі вивчення іноземної мови у ВНЗ (на прикладі кінофільму «Звуки музики» («The Sound of Music»), США, реж. Уайз, 1965 р.). Актуальні проблеми навчання та виховання людей в інтегрованому середовищі: зб. наук. праць № 9 (11). Київ: Університет «Україна». 2012. С. 84-95.

9. Плахотнік О. В., Васильєва-Халатникова М. О. Професійна рефлексія у діяльності соціального педагога: навч.-метод. посібник. - Київ, 2013. - 248 с.

10. Чернуха Н.M. Формирование социальной активности студентов в современном интеграционном образовательном пространстве. Освітня політика держави : філософія, методологія, практика. Тематичний випуск. Київ, 2014. С. 137140.

11. Чернуха Н.М., Асланов Г. Соціальні комунікації в інтеркультурному просторі: відповідь на виклики сьогодення. Innovative processes in education: Collective monograph. - AMEET Sp. z o.o., Lodz, Poland, 2017.

12. Kulyk Olena. Reflection as a component to professional becoming tomorrow's specialist in the higher education system. Topical questions of contemporary science: Collection of scientific articles. Aspekt Publishing of Budget Printing Center, Taunton, MA 02780, United States of America, 2017. P. 441-447.

13. Shkolna Maria. Pedagogical conditions for upbringing social maturity of students' agricultural colleges. Intellectual Archive. Toronto: Shiny Word.Corp. (Canada). 2017. September/October. Vol. 6. No. 5. PP. 79-85. 


\section{Manuscript Guidelines}

1. All submitted papers must contain the Title, Name of author(s), Affiliation (if any), Abstract and List of References (Literature) written in English. The Abstract must count not less than 100 and not more than 300 words and must be the good representation of your article. Optionally paper may also contain this information duplicated in another language.

2. Font faces. Arial, Times, Times New Roman, Courier New and Helvetica.

3. Language. You may use any language for your paper text, however English is MUCH preferable.

4. Title. Font size - 16, bold. Position - central alignment.

5. The author's name. Font size - 14, bold. Position - central alignment.

6. The affiliation (your University etc). Font size - 14, regular (not bold). Position - left alignment.

7. The word "Abstract". Font size - 12, bold-italics. Position - central alignment.

8. The text of the abstract. Font size - 10, regular (not bold).

9. The word "Keywords" (if any). Font size - 10, bold. Position - left alignment.

10. The text of keywords (if any). Font size - 10, regular (not bold). Position - left alignment.

11. Text of article. Font size - 14. Position - left alignment or fully justified. Line spacing - 1.5 lines.

12. The word "References" (if any). Font size - 12, bold-italics. Position - central alignment.

13. The text of References (if any). Font size - 12, regular (not bold).

In all other cases please use your own good judgment or contact our Editorial Board.

\section{Where to find us}

The "IntellectualArchive" is distributed to major libraries across Canada and the US, including

Library of Congress, USA (http://lccn.loc.gov/cn2013300046 ) ,

Library and Archives Canada

(http://collectionscanada.gc.ca/ourl/res.php?url_ver=Z39.88-2004\&url_tim=2012-09-

05T01\%3A46\%3A54Z\&url_ctx_fmt=info\%3Aofi\%2Ffmt\%3Akev\%3Amtx\%3Actx\&rft_dat=40904933\&r

fr_id=info\%3Asid\%2Fcollectionscanada.gc.ca\%3Aamicus\&lang=eng) and others.

The references to articles published in the "IntellectualArchive" are available in the

Google Scholar, (http://scholar.google.ca/scholar?q=\%22IntellectualArchive\%22 ),

Arxiv.org (http://search.arxiv.org:8081/?query=\%22Intellectual\%20Archive\%22\&in= ),

WorldCat.org (https://www.worldcat.org/search?q=n2\%3A1929-4700\&qt=advanced \&dblist=638 ) ,

Academia.edu

(http://www.academia.edu/15503799/Light_diffraction_experiments_that_confirm_the_STOE_model_and

_reject_all_other_models )

The National Research Council (Italy) (http://data.cnr.it/data/cnr/individuo/rivista/ID658222 )

Наукова бібліотека of the University named after Dragomanov, Ukraine

(http://enpuir.npu.edu.ua/handle/123456789/7974?mode=full )

Google.com (https://www.google.ca/\#q=site:IntellectualArchive.com ) thousands of links etc. 